\title{
Organic milk: Understanding intrinsic characteristics and their origin, and development of novel means of detection
}

Ningjing Liu 


\section{Thesis committee}

\section{Promotor}

Prof. Dr S.M. van Ruth

Special professor, Food Authenticity and Integrity

Wageningen University \& Research

\section{Co-promotors}

Dr K.A. Hettinga

Associate professor, Food Quality and Design

Wageningen University \& Research

Dr A.M. Pustjens

Project leader, Wageningen Food Safety Research

Wageningen University \& Research

\section{Other members}

Dr J. Dijkstra, Wageningen University \& Research

Prof. Dr W. Vetter, Universität Hohenheim, Germany

Dr H. van den Bijgaart, Qlip N.V.

Dr F.B. Biasioli, Fondazione Edmund Mach di San Michele all'Adige, Italy

This research was conducted under the auspices of the Graduate School VLAG (Advanced studies in Food Technology, Agrobiotechnology, Nutrition and Health Sciences) 


\section{Organic milk: Understanding intrinsic characteristics and their origin, and development of novel means of detection}

\section{Ningjing Liu}


Ninging Liu

Organic milk: Understanding intrinsic characteristics and their origin, and development of novel means of detection,

152 pages.

$\mathrm{PhD}$ thesis, Wageningen University, Wageningen, the Netherlands (2020)

With references, with summary in English

ISBN: 978-94-6395-398-6

DOI: https://doi.org/10.18174/521401 


\section{Table of contents}

Chapter 2 Dairy farming system markers: The correlation of forage and milk fatty acid profiles from organic, pasture, and conventional systems in the Netherlands

Chapter 3 Tracking volatile organic compounds from forage to milk for different production systems

Chapter 4 Evaluation of portable near-infrared spectroscopy for organic milk authentication

Chapter 5 How organic is organic milk? Can we have a quick check?

Chapter 6 Portraying and tracing the impact of different production systems on the volatile organic compound composition of milk by PTR(Quad)MS and PTR-(ToF)MS

Chapter 7 General discussion

Summary 


\section{Chapter 1}

General introduction 


\subsection{Organic products}

\subsubsection{Societal development}

Due to the rapid growth of the world population, farmers try various ways to improve the production of agricultural products, including the use of synthetic fertilizers, pesticides, herbicides, and other intensive agricultural strategies. Such activities secured the production of sufficient food, but also brought some other issues. Over-exploitation made the world suffer from the greenhouse effect, soil erosion, water pollution, and other side effects (Altieri, 2018). Being aware of the seriousness of this problem, some groups of farmers started to shift towards a more environmentally sustainable, agricultural strategy. As one of such strategies, the concept of organic agriculture was proposed.

In 2007, the European Commission issued Regulation (EEC) No 2092/91 (Commission, 2007) to regulate the production of organic products in the European Union (EU). This standard not only regulates the use of pesticides, hormones, and other drugs in organic production systems, but also emphasizes the importance of animal welfare. The aim of organic agriculture is to reduce the damage to the environment during cultivation and to generate a positive impact on soil quality, biodiversity preservation, and rural development (Padel, 2001).

\subsubsection{Organic market}

In Europe, organic agriculture has been promoted due to the increased interests of the quality of agricultural products, health issues, and inhabitants' living environment. As a result, a considerable growth in the organic market has been seen in the last decade. The sales of organic agricultural products in the EU have increased by $10 \%$ annually. In 2007 , there were only 7.8 million hectares of organic agricultural land and 16 billion euros worth of products sold (Willer, Lernoud, Huber, \& Sahota, 2009). However, by the end of 2017, the total area of organic agricultural land in the EU had reached 12.8 million hectares, taking up more than $7 \%$ of the total arable land area, and the total revenue for organic products sold within the EU reached 34 billion euros (Willer, Schaack, \& Lernoud, 2019).

\subsubsection{Fraud with organic products}

Strict management rules limit the production yield of organic products, making it lower than the yield of conventional products. On the other hand, the demand for organic products keeps growing. As a result, the price of organic products is higher than the price of conventional products. Meanwhile, this makes organic products vulnerable to fraud. Some food chain actors could replace expensive organic products with lower-priced non-organic products to achieve illegal profits. According to a report published by Polderman, Cammelbeeck, Uitslag, and Gouw (2016), about 33\% of the organic products sold in supermarkets and about $18 \%$ of the organic products sold in health food stores are suspected of fraud. Such fraud can lead to scandals, reports that can be found in both scholarly literature and social media (Marian \& 
Thøgersen, 2013; Müller \& Gaus, 2015; Raszap Skorbiansky \& Ferreira, 2018). Those unwanted behaviours not only cause financial loss to involved organic stakeholders, but also damage the reputation of the entire organic sector. Organic farmers and processors would then have to compete with conventional products that are produced at lower costs but marketed with the organic premium. This puts actors who produce and sell authentic organic products at an unfair disadvantage. In addition, consumers may lose their trust in the information of organic labels and decrease their willingness to purchase organic products. Hence, there is a need to ensure the integrity of the products in order to safeguard the organic production and market.

\subsection{Organic milk}

\subsubsection{Organic milk market}

Organic milk is one of the most well-known organic products. An increasing number of farmers decided to convert from conventional dairy farming to organic dairy farming. The willingness to convert to organic dairy farming depends on many factors. One of the reasons is that organic dairy is treated as a potential solution to some current problems (Hafla, MacAdam, $\&$ Soder, 2013). The introduction of the organic concept brings a new direction to dairy farming. Organic regulations not only strictly limit the usage of antibiotics and hormones, but also focus more on animal welfare and sustainability. Another reason for the increasing number of conversions is that farmers wish to distinguish their products from those of others. Since the EU cancelled the milk quota in 2015, there is no production restriction anymore and the milk price is more fluctuating, which resulted in more intense competition in the dairy sector. Because of this, certain groups of dairy farms try to make their products stand out in the market by converting their production system to organic.

In 2017 , organic dairy products accounted for about $4 \%$ of the total dairy market in the Netherlands. There were more than 500 organic dairy farms in the Netherlands with approximately 32,000 cows in that year (Eurostat, 2019a) producing 248 million litres of milk (Eurostat, 2019b). The purchase of organic products by consumers is based on marketing variables (price, quality) and perceived value as well (Hemmerling, Hamm, \& Spiller, 2015). The yearly production in the organic dairy sector is around $6000 \mathrm{~kg}$ milk per cow, while the average yearly production in the conventional dairy sector is around $8500 \mathrm{~kg}$ milk per cow (Eurostat, 2019c).

\subsubsection{Requirements for organic milk production}

Organic dairy farming in EU should meet the requirements in European regulations (Commission, 2007), which includes the following rules. Firstly, cows should have access to grassland without limitation. Secondly, at the stable, cows should stand on straw and be able to let manure fall on the straw. The building should permit enough natural ventilation and light to enter. Thirdly, the percentage of roughage (organic grass, organic hay, and organic corn, which 
may not contain genetically modified ingredients) should not be less than $60 \%$ of the total intake. Fourthly, grassland is partly sown with clover as a natural fertilizer. Pesticides and herbicides may not be used for feed production. Fifthly, when milking is stopped, antibiotics may not be preventatively used to udder inflammation.

In the Netherlands, the control authority for organic production is 'Skal Biocontrole', which is dedicated to inspecting the reliability of organic products, as assigned by the Minister of Agriculture, Nature and Food Quality. During audits and inspections, the production process is looked over to ensure that environmental care and animal welfare are contemplated. Meanwhile, 'Skal Biocontrole' is responsible for the certification of organic processing companies in the Netherlands as well. Farmers who comply with all the regulations will receive permission for using the EU organic logo.

\subsubsection{Other milk production systems in the Netherlands}

In addition to organic milk, two other types of milks are produced in different production systems in the Netherlands, i.e. conventional milk and a green production type of milk, called pasture milk.

Conventional milk is obtained from cows that mostly stay inside the stable. Cows from conventional farms are fed with silages and concentrates every day. Conventional cows may occasionally go outside, but pasture grazing is not required. In the Netherlands, compared with organic farms, conventional farms usually have more cattle, less arable land, and a higher milk production per cow (Thomassen, van Calker, Smits, Iepema, \& de Boer, 2008). Since the EU milk quota system was ended in 2015, some dairy farmers increased the number of dairy cows to produce more milk, without purchasing more land simultaneously (Klootwijk, Van Middelaar, Berentsen, \& de Boer, 2016). This further reduced the grassland area per cow and the time of grazing outdoors.

On the contrary, in 2007, another part of dairy farmers, collaborating with the Dutch grazing foundation, proposed a type of green production of milk, called pasture milk ('weidemelk' in Dutch). They encourage dairy farmers to have their cows graze in the meadow, which is supposed to be a part of the traditional Dutch landscape. According to the guidelines of 'weidemelk' (Weidegang, 2018), pasture milk is the milk from cows that are grazing outdoors for at least six hours a day for at least 120 days per year. Pasture milk can be recognized by the 'weidemelk' logo on the packaging. To promote this concept, many dairy companies in the Netherlands pay a premium for this type of milk.

\subsection{Distinct characteristics of organic milk}

Since organic products are vulnerable to fraud (Müller \& Gaus, 2015), research has been carried out to investigate the specific traits of organic milk to develop method to detect fraud. Researchers are trying to explore the differences between organic milk and other milks, which would allow analytical distinction and ultimately verification of organic milk. They may also 
study these differences from a nutritional perspective. Since the management strategies in the various dairy production systems are different, there is an assumption that each type of milk has its own compositional characteristics. The gross compositional profile of raw milk is shown in Table 1.1. It shows that besides water, the major compounds of milk include protein, lipids, sugars, minerals, and vitamins. Therefore, many studies focus on these constituents groups. Analytical methods that have previously been used for the distinction of organic milk are discussed in the paragraphs below.

Table 1.1 Gross composition of raw milk*.

\begin{tabular}{lll}
\hline Nutrient & Unit & Value per 100g \\
\hline Water & $\mathrm{g}$ & 86.5 \\
Total lipids (fat) & $\mathrm{g}$ & 4.4 \\
Sugars, total & $\mathrm{g}$ & 4.4 \\
Protein & $\mathrm{g}$ & 3.4 \\
Vitamins, total & $\mathrm{mg}$ & 1.9 \\
Minerals, total & $\mathrm{g}$ & 0.4 \\
*Compiled from the Dutch Food Composition Database (NEVO, 2019).
\end{tabular}

\subsubsection{Fatty acids}

Differences in fatty acids (FAs) between organic and non-organic milks have been the topic of various studies. Butler, Stergiadis, Seal, Eyre, and Leifert (2011) studied retail organic and conventional milks from 2006 to 2008 in northeast England. Their results suggested that organic milk contained a higher concentration of polyunsaturated fatty acids (PUFA). Similar results have been obtained by other researchers (Adler, Jensen, Govasmark, \& Steinshamn, 2013; Tsiplakou, Kotrotsios, Hadjigeorgiou, \& Zervas, 2010). O’Donnell, Spatny, Vicini, and Bauman (2010) revealed that the higher level of PUFA in organic milk is related to outdoor grazing. Because of the perceived additional health value, $\alpha$-linolenic acid is an important PUFA. Increased levels of $\alpha$-linolenic acid have been found in organic milk (Capuano, Grevink, Boerrigter-Eenling, \& van Ruth, 2015a, 2015b; Pilarczyk, Wojcik, Sablik, \& Czerniak, 2015; Schwendel, Morel, Wester, Tavendale, Deadman, Fong, et al., 2015; Tunick, Paul, Ingham, Karreman, \& Van Hekken, 2015). A higher proportion of fresh grass in the feed has a direct influence on the level of $\alpha$-linolenic acid (Schröder, Yousefi, \& Vetter, 2011). Besides $\alpha$ linolenic acid, conjugated linoleic acids (CLAs) are also abundant in organic milk (Khan, Yu, Ali, Cone, \& Hendriks, 2015; Capuano, Boerrigter-Eenling, van der Veer, \& van Ruth, 2013). CLAs are a mixture of positional and geometric isomers of linoleic acid (C18:2) with conjugated unsaturated double bonds. The concentrations of CLA in milks are not only affected by the extent of grazing, but also by the proportion of maize in the dairy feed (Capuano, Boerrigter-Eenling, van der Veer, \& van Ruth, 2013). These previous findings make the analyses of FAs of potential interest to discriminate organic milk against other milks in both summer (based on the frequency of grazing) and winter (based on the amount of maize in the feed). 


\subsubsection{Proteins and lactose}

As major components, proteins and lactose do not show significantly different levels in organic milk and non-organic milk (Kuczyńska, Puppel, Gołębiewski, Metera, Sakowski, \& Słoniewski, 2012; Toledo, Andrén, \& Björck, 2002). The composition of proteins in milk are more related to the genetic background of cow breeds (Markiewicz-Kęszycka, Wójtowski, Kuczyńska, Puppel, Czyżak-Runowska, Bagnicka, et al., 2013). However, there are no major differences in dairy breeds between organic and conventional cows.

\subsubsection{Vitamins}

Milk is one of the most important sources of fat-soluble vitamins (Bergamo, Fedele, Iannibelli, \& Marzillo, 2003). The concentrations of vitamin A, D3, and E are significantly higher in organic milk than their respective concentrations in conventional milk, as well as the concentration of $\beta$-carotene, which is a precursor of vitamin A (Brodziak, Król, Litwińczuk, \& Barłowska, 2018). Among all these compounds, $\beta$-carotene, which causes the yellow colour of milk fat, is one of the most significant compounds. $\beta$-carotene content in milk is strongly dependent on the nature of the diet (Walstra, Wouters, \& Geurts, 2005). Fresh grass is the main source of $\beta$-carotene in milk. In May and June, $\beta$-carotene peak concentrations in grass of 620 $700 \mathrm{mg} / \mathrm{kg}$ dry matter (DM) have been observed (Prache, Priolo, \& Grolier, 2003). Compared to fresh forage, dehydrated forage contains lower level of carotenoids (Prache, Priolo, Tournadre, Jailler, Dubroeucq, Micol, et al., 2002). The ensiling process of forage decreases carotenoid concentration as well, with losses varying from $20 \%$ to $80 \%$ (Nozière, Graulet, Lucas, Martin, Grolier, \& Doreau, 2006). The largest differences of the milk $\beta$-carotene concentrations between organic and non-organic milk appear in summer, because in summer organic cows are provided with fresh grass and non-organic cows are provided with grass and maize silages. In winter, on the other hand, the differences of the concentrations of $\beta$-carotene between organic and non-organic milk are smaller, because both organic and conventional farms provide silages during that period.

\subsubsection{Minerals}

The analysis of mineral elements has shown to provide useful information for the distinction of organic milk as well. The levels of elements in milks depend on the mineral content of feedstuffs. It has been observed that the levels of selenium and iodine are significantly higher in non-organic milk compared to organic milk (Bath \& Rayman, 2016; Średnicka-Tober, Barański, Seal, Sanderson, Benbrook, Steinshamn, et al., 2016). This is because non-organic dairy farmers add selenium and iodine supplements into feedstuffs to improve the reproduction performance and infection resistance, respectively (RodríguezBermúdez, López-Alonso, Miranda, Fouz, Orjales, \& Herrero-Latorre, 2018). Meanwhile, some studies found that a lower amount of Iodine in organic milk could also be related to the 
higher percentages of clover in organic feed (Bath \& Rayman, 2016; Flachowsky, Franke, Meyer, Leiterer, \& Schöne, 2014). Cyanogenic glucosides contained in white clover could act as competitive inhibitors of iodine transport. They disturb the mammary Iodine transportation. According to the research by Bath and Rayman (2016), the concentrations of Iron in organic milk $(0.74 \mathrm{mg} / \mathrm{kg})$ was significantly $(\mathrm{P}=0.034)$ higher than the concentrations in conventional milk (0.64 mg/kg). Rey-Crespo, Miranda, and López-Alonso (2013) observed higher concentrations of cupper, selenium, and zinc in conventional milk, and related the abundance of mineral elements to the widespread use of supplementations in concentrate feed. However, such results are not universal. López-Alonso, Rey-Crespo, Herrero-Latorre, and Miranda (2017) proposed that grazing outdoors could increase the intake of mineral elements. The ingestion of soil and soil-contaminated plants during grazing contributes to the levels of mineral elements as well. In this case, the differences of the concentrations of elements between organic milk and non-organic milk could be affected and result in distinct patterns.

\subsubsection{Volatile organic compounds}

Volatile organic compounds (VOCs) are present in milk at low concentrations, and can be affected by many factors, including environment, breed, and lactation stage (Gandy, Schilling, Coggins, White, Yoon, \& Kamadia, 2008; Yasuko, Sadaki, Makoto, \& Fumiaki, 2016) as well as the composition of the feed and its interaction with the rumen metabolism (Villeneuve, Lebeuf, Gervais, Tremblay, Vuillemard, Fortin, et al., 2013). The latter two factors could be directly linked to the characteristics of organic milk. Furthermore, fatty acids, which are potential biomarkers of organic milk, can also have an impact on the VOCs in milks, since some VOCs in milks are short chain volatile FAs or generated from breakdown of long chain FAs (Toso, Procida, \& Stefanon, 2002). These facts suggest that organic milk could have different concentrations of VOCs compared to other milks, but the consistency of these differences needs to be confirmed.

\subsubsection{Stable isotope ratios}

For most of organic compounds in milk, hydrogen, carbon, nitrogen, and oxygen are the basic elements. Similar to other light elements, hydrogen, carbon, and oxygen contain different ratios of at least two stable isotopes, which contain the same number of protons but a different number of neutrons. The ratios of stable isotopes are affected by external and internal factors and contain, for example, information on the geographical and botanical origins of different products. To obtain a uniform standard, the stable isotope ratio in a product is calculated with a reference standard (Laursen, Schjørring, Kelly, \& Husted, 2014):

$$
\delta(\%)=\left(R_{\text {sample }} / R_{\text {standard }}-1\right) * 1000
$$

Where $R_{\text {sample }}$ is the isotope ratio in the sample (the heavy isotope to the light one, like ${ }^{15} \mathrm{~N} /{ }^{14} \mathrm{~N}$ or ${ }^{13} \mathrm{C} /{ }^{12} \mathrm{C}$ ), and the $R_{\text {standard }}$ is the isotope ratio in the international standard reference. 
The stable isotope ratios in milk, including $\delta^{2} \mathrm{H}, \delta^{13} \mathrm{C}, \delta^{15} \mathrm{~N}, \delta^{18} \mathrm{O}$, and $\delta^{34} \mathrm{~S}$ differ according to the types and sources of feed, which in turn are closely related to the dairy production systems. Therefore, a series of research studies have been carried out to study the differences of the stable isotope ratio in organic and other milks (Kaffarnik, Schröder, Lehnert, Baars, \& Vetter, 2014; Molkentin, 2009; Molkentin \& Giesemann, 2007, 2010). By examining the stable isotope ratio of carbon, it was possible to distinguish organic milk from other milks, because of the different grass to maize ratio in organic and conventional feed. Generally, the percentage of maize in organic feed is lower than in non-organic feed. Because of the higher cost of cultivating organic maize and the concept of natural feeding, organic farmers tend to provide more grass and less maize to their cows. On the contrary, non-organic farmers offer cows more maize, which is relatively cheap and can significantly increase the milk production (O'Mara, Fitzgerald, Murphy, \& Rath, 1998). As a type of $\mathrm{C}_{4}$ plant, maize has higher percentages of ${ }^{13} \mathrm{C}\left(\delta^{13} \mathrm{C}\right.$ varying from $-9 \%$ o to $-20 \%$ ), while as a type of $\mathrm{C}_{3}$ plant, grass has lower percentages of ${ }^{13} \mathrm{C}\left(\delta^{13} \mathrm{C}\right.$ varying from $-21 \%$ o to $-35 \%$ ) (Chung, Park, Yoon, Yang, \& $\mathrm{Kim}, 2014)$. Besides the isotopic ratio of carbon, the isotopic ratio of nitrogen could help to authenticate organic milk as well. The theoretical basis is that $\delta^{15} \mathrm{~N}$ in animal manure (used in organic farms) is significantly higher than the $\delta^{15} \mathrm{~N}$ in synthetic fertilizer (used in conventional farms) (Choi, Kwak, Lim, Park, Chang, Lee, et al., 2017). Via bioaccumulation, the differences of $\delta^{15} \mathrm{~N}$ will also be present in milks (Erasmus, Muller, van der Rijst, \& Hoffman, 2016). However, according to previous studies (Molkentin \& Giesemann, 2007), the differences of $\delta$ ${ }^{15} \mathrm{~N}$ between organic milk and other milks are less significant than the differences of $\delta^{13} \mathrm{C}$. This could be explained by legume cultivation in organic farms, which are planted to utilize the nitrogen from the air as an extra nitrogen fertilizer. The nitrogen fertilizer generated by organic legumes will decrease the $\delta^{15} \mathrm{~N}$ in organic farms (Schmidt, Roßmann, Voerkelius, Schnitzler, Georgi, Graßmann, et al., 2005). Moreover, since the population in conventional livestock is higher, non-organic farmers tend to get rid of manure by applying it to grasslands, just as organic farmers, which causes more ${ }^{15} \mathrm{~N}$ from manure to end up in conventional feed (Molkentin \& Giesemann, 2010). The isotope ratios of other elements, such as hydrogen, oxygen, and sulphur, tend to be more related to the geographical origin than the production system (Schmidt, et al., 2005). Overall, $\delta^{13} \mathrm{C}$ could partly reflect the amount of maize incorporated in feed, which is a part of the characteristics of organic dairy feed, while other stable isotope ratios are less likely to bring organic-related information.

\subsection{Laboratory-based methods and beyond}

Aiming at the characteristics mentioned in the previous section, several methods have been developed, e.g. gas chromatography (GC) for the analysis of FAs, nuclear magnetic resonance (NMR) for the metabolomics of lipid fractions (Tsiafoulis, Papaemmanouil, Alivertis, Tzamaloukas, Miltiadou, Balayssac, et al., 2019), high-performance liquid 
chromatography (HPLC) for the analysis of vitamins (Martin, Cornu, Kondjoyan, Ferlay, Verdier-Metz, Pradel, et al., 2005), inductive coupled plasma mass spectrometry (ICP-MS) for the detection of elements (Barbosa, Batista, Varrique, Coelho, Campiglia, \& Barbosa Jr, 2014), gas chromatography-mass spectrometry (GC-MS) for the analysis of VOC (Yasuko, Sadaki, Makoto, \& Fumiaki, 2016), and isotope-ratio mass spectrometry (IRMS) for the analysis of stable isotope ratios (Bateman, Kelly, \& Jickells, 2005). All of these methods, which cover a wide range of analytical techniques, involve advanced precision instruments, which require an advanced laboratory with experienced operators. The application of spectroscopy, such as Raman spectroscopy and Fourier transform infrared spectroscopy, relatively decreases the analysis time (Capuano, Rademaker, van den Bijgaart, \& van Ruth, 2014; Smigic, Djekic, Tomasevic, Stanisic, Nedeljkovic, Lukovic, et al., 2017), but the commonly used benchtop instruments are not portable. To ensure the authenticity of organic milk, analysis should not be limited to labs, but be applied beyond labs, too.

Over the last five to ten years, there have been developments in the area of miniaturisation of analytical equipment. Portable near infrared spectroscopy (NIRS) equipment is an example (Dos Santos, Lopo, Páscoa, \& Lopes, 2013), which has been applied in many fields of food authentication (Basri, Hussain, Bakar, Sharif, Khir, \& Zoolfakar, 2017; Fernández-Espinosa, 2016; Henn, Schwab, \& Huck, 2016; Mabood, Jabeen, Ahmed, Hussain, Al Mashaykhi, Al Rubaiey, et al., 2017; Malegori, Nascimento Marques, de Freitas, Pimentel, Pasquini, \& Casiraghi, 2017). Compared with lab-based analysis instruments, portable NIRS has a higher analysis speed and is easier to operate. Although the sensitivity is lower than its benchtop counterparts, combined with regularly updated chemometrics models, such a technique may help to ensure the integrity of organic dairy products.

\subsection{Research gap}

Although some of the characteristics of organic milk have been studied before, the underlying causes for the differences compared to other milks are not fully known. Organic milk is unique because of its special management specifications. Compared with a non-organic dairy system, the organic dairy system differs mainly because of the use of organic feed and outdoor grazing. The features of organic feed are determined by two aspects: their botanical origin and production system. Those aspects may contribute to a distinct compositional profile of organic milk, both directly and indirectly. Meanwhile, pasture milk may make the distinction more complicated as it is positioned between conventional and organic milk in terms of management. To ensure the reliability of organic milk detection methods, it is necessary to clarify the consistent differences between organic milk and other milks, and prove that these differences are the result of the specific requirements for organic dairy systems. 


\subsection{Research objectives and thesis outline}

The main research objective of this thesis is to elucidate the differences between organic milk and other milks, to study their underlying causes, and to develop novel detection methods. Since the major differences are expected for FA and VOC compositions (see Section 1.3), the thesis will focus on these constituents. The main objective has been divided into the following sub-objectives:

- To elucidate the unique features of organic milk in comparison to pasture and conventional milks in regard to their FA compositions and explore the causes of the features.
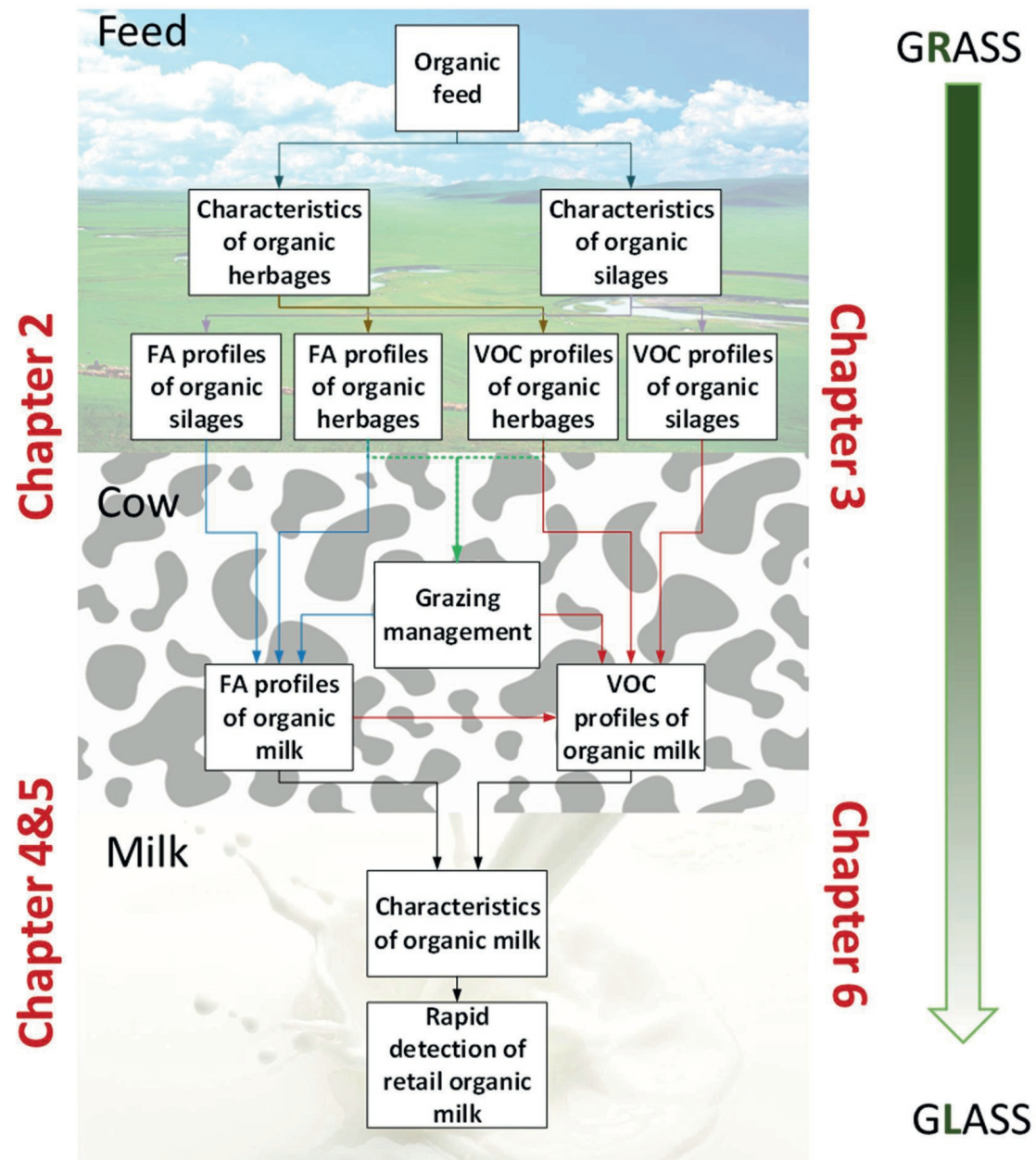

Fig. 1.1 Schematic representation of the main objective and sub-objectives of the thesis. 
- To elucidate the unique features of organic milk in comparison to pasture and conventional milks in regard to their VOC compositions and explore the causes of the features.

- To critically compare and rank analysis approaches for various stakeholder groups. The $\mathrm{PhD}$ study is outlined as follows and its parts are illustrated in Fig. 1.1. Chapter 1 provides a general introduction to the thesis, which includes the background information and the scientific questions of the thesis. In Chapters $\mathbf{2}$ and $\mathbf{3}$, the differences between organic, pasture, and conventional feeds, in summer and winter, and resulting raw milks are examined. The results are used to determine consistent differences between systems and to understand underlying management causes for these differences. The first study focuses on FAs (Chapter 2) and the second one on VOCs (Chapter 3). Chapter 4 involves a study that deals with the development of a rapid, portable analysis method for distinction of organic milk by using a portable NIRS device in combination with classification statistics. The extent to which spectral information is derived from the FA composition of the milks is examined too. Furthermore, the performance of this newly developed rapid detection method is compared with laboratory-based instrumentation. In Chapter 5, a consumer NIRS device is evaluated for its discriminatory capacity between organic retail milk and conventional retail milk. In Chapter 6, retail milks from the three production systems are compared for their VOC compositions and classification models are developed in order to examine suitability of the VOCs for organic milk authentication. In Chapter 7, results from Chapter 2 to Chapter 6 are discussed and integrated. The impact of the research described in this thesis, together with the implications, limitations, and recommendations for further research are discussed, and the final conclusions of the thesis are presented. 


\subsection{References}

Adler, S. A., Jensen, S. K., Govasmark, E., \& Steinshamn, H. (2013). Effect of short-term versus long-term grassland management and seasonal variation in organic and conventional dairy farming on the composition of bulk tank milk. Journal of Dairy Science, 96(9), 5793-5810.

Altieri, M. A. (2018). Agroecology: the science of sustainable agriculture: CRC Press.

Barbosa, R. M., Batista, B. L., Varrique, R. M., Coelho, V. A., Campiglia, A. D., \& Barbosa Jr, F. (2014). The use of advanced chemometric techniques and trace element levels for controlling the authenticity of organic coffee. Food Research International, 61(0), 246251.

Basri, K. N., Hussain, M. N., Bakar, J., Sharif, Z., Khir, M. F. A., \& Zoolfakar, A. S. (2017). Classification and quantification of palm oil adulteration via portable NIR spectroscopy. Spectrochimica Acta Part A: Molecular and Biomolecular Spectroscopy, 173, 335-342.

Bateman, A. S., Kelly, S. D., \& Jickells, T. D. (2005). Nitrogen Isotope Relationships between Crops and Fertilizer: Implications for Using Nitrogen Isotope Analysis as an Indicator of Agricultural Regime. Journal of Agricultural and Food Chemistry, 53(14), 57605765.

Bath, S. C., \& Rayman, M. P. (2016). Trace element concentration in organic and conventional milk: what are the nutritional implications of the recently reported differences? British Journal of Nutrition, 116(1), 3-6.

Bergamo, P., Fedele, E., Iannibelli, L., \& Marzillo, G. (2003). Fat-soluble vitamin contents and fatty acid composition in organic and conventional Italian dairy products. Food Chemistry, 82(4), 625-631.

Brodziak, A., Król, J., Litwińczuk, Z., \& Barłowska, J. (2018). Differences in bioactive protein and vitamin status of milk from certified organic and conventional farms. International Journal of Dairy Technology, 71(2), 321-332.

Butler, G., Stergiadis, S., Seal, C., Eyre, M., \& Leifert, C. (2011). Fat composition of organic and conventional retail milk in northeast England. Journal of Dairy Science, 94(1), 24 36.

Capuano, E., Boerrigter-Eenling, R., van der Veer, G., \& van Ruth, S. M. (2013). Analytical authentication of organic products: an overview of markers. Journal of the Science of Food and Agriculture, 93(1), 12-28.

Capuano, E., Grevink, R., Boerrigter-Eenling, R., \& van Ruth, S. M. (2015a). Fatty acid and triglycerides profiling of retail organic, conventional and pasture milk: Implications for health and authenticity. International Dairy Journal, 42, 58-63. 
Capuano, E., Grevink, R., Boerrigter-Eenling, R., \& van Ruth, S. M. (2015b). Fatty acid and triglycerides profiling of retail organic, conventional and pasture milk: Implications for health and authenticity. International Dairy Journal, 42(0), 58-63.

Capuano, E., Rademaker, J., van den Bijgaart, H., \& van Ruth, S. M. (2014). Verification of fresh grass feeding, pasture grazing and organic farming by FTIR spectroscopy analysis of bovine milk. Food Research International, 60, 59-65.

Choi, W.-J., Kwak, J.-H., Lim, S.-S., Park, H.-J., Chang, S. X., Lee, S.-M., Arshad, M. A., Yun, S.-I., \& Kim, H.-Y. (2017). Synthetic fertilizer and livestock manure differently affect $\delta 15 \mathrm{~N}$ in the agricultural landscape: A review. Agriculture, Ecosystems \& Environment, 237, 1-15.

Chung, I.-M., Park, I., Yoon, J.-Y., Yang, Y.-S., \& Kim, S.-H. (2014). Determination of organic milk authenticity using carbon and nitrogen natural isotopes. Food Chemistry, 160(0), 214-218.

Commission, E. (2007). Regulation (EEC) No 2092/91 organic production and labelling of organic products and repealing. In Official Journal of the European Union L, vol. 189 (pp. 28.27). Brussels.

Dos Santos, C. A. T., Lopo, M., Páscoa, R. N., \& Lopes, J. A. (2013). A review on the applications of portable near-infrared spectrometers in the agro-food industry. Applied Spectroscopy, 67(11), 1215-1233.

Erasmus, S. W., Muller, M., van der Rijst, M., \& Hoffman, L. C. (2016). Stable isotope ratio analysis: A potential analytical tool for the authentication of South African lamb meat. Food Chemistry, 192, 997-1005.

Eurostat. (2019a). Organic livestock of animals. Retrieved on October 27, 2019, from https://appsso.eurostat.ec.europa.eu/nui/show.do?dataset=org_lstspec\&lang=en.

Eurostat. (2019b). Organic production of animal products. Retrieved on October 27, 2019, from https://appsso.eurostat.ec.europa.eu/nui/show.do?dataset=org_aprod.

Eurostat. (2019c). Cows'milk collection and products obtained - annual data. Retrieved on October 27, 2019 from https://appsso.eurostat.ec.europa.eu/nui/show.do?dataset =apro_mk_cola\&lang=en.

Fernández-Espinosa, A. J. (2016). Combining PLS regression with portable NIR spectroscopy to on-line monitor quality parameters in intact olives for determining optimal harvesting time. Talanta, 148, 216-228.

Flachowsky, G., Franke, K., Meyer, U., Leiterer, M., \& Schöne, F. (2014). Influencing factors on iodine content of cow milk. European Journal of Nutrition, 53(2), 351-365.

Gandy, A. L., Schilling, M. W., Coggins, P. C., White, C. H., Yoon, Y., \& Kamadia, V. V. (2008). The Effect of Pasteurization Temperature on Consumer Acceptability, Sensory Characteristics, Volatile Compound Composition, and Shelf-Life of Fluid Milk. Journal of Dairy Science, 91(5), 1769-1777. 
Hafla, A.N.; MacAdam, J.W.; Soder, K.J. Sustainability of US Organic Beef and Dairy Production Systems: Soil, Plant and Cattle Interactions (2013). Sustainability ,5, 30093034.

Hemmerling, S., Hamm, U., \& Spiller, A. (2015). Consumption behaviour regarding organic food from a marketing perspective - a literature review. Organic Agriculture, 5(4), 277 313.

Henn, R., Schwab, A., \& Huck, C. W. (2016). Evaluation of benchtop versus portable nearinfrared spectroscopic method combined with multivariate approaches for the fast and simultaneous quantitative analysis of main sugars in syrup formulations. Food Control, $68,97-104$.

Kaffarnik, S., Schröder, M., Lehnert, K., Baars, T., \& Vetter, W. (2014). $\delta 13$ C values and phytanic acid diastereomer ratios: combined evaluation of two markers suggested for authentication of organic milk and dairy products. European Food Research and Technology, 238(5), 819-827.

Khan, N. A., Yu, P., Ali, M., Cone, J. W., \& Hendriks, W. H. (2015). Nutritive value of maize silage in relation to dairy cow performance and milk quality. Journal of the Science of Food and Agriculture, 95(2), 238-252.

Klootwijk, C. W., Van Middelaar, C. E., Berentsen, P. B. M., \& de Boer, I. J. M. (2016). Dutch dairy farms after milk quota abolition: Economic and environmental consequences of a new manure policy. Journal of Dairy Science, 99(10), 8384-8396.

Kuczyńska, B., Puppel, K., Gołębiewski, M., Metera, E., Sakowski, T., \& Słoniewski, K. (2012). Differences in whey protein content between cow's milk collected in late pasture and early indoor feeding season from conventional and organic farms in Poland. Journal of the Science of Food and Agriculture, 92(14), 2899-2904.

Laursen, K. H., Schjørring, J. K., Kelly, S., \& Husted, S. (2014). Authentication of organically grown plants-advantages and limitations of atomic spectroscopy for multi-element and stable isotope analysis. TrAC Trends in Analytical Chemistry, 59, 73-82.

López-Alonso, M., Rey-Crespo, F., Herrero-Latorre, C., \& Miranda, M. (2017). Identifying sources of metal exposure in organic and conventional dairy farming. Chemosphere, 185, 1048-1055.

Mabood, F., Jabeen, F., Ahmed, M., Hussain, J., Al Mashaykhi, S. A. A., Al Rubaiey, Z. M. A., Farooq, S., Boqué, R., Ali, L., Hussain, Z., Al-Harrasi, A., Khan, A. L., Naureen, Z., Idrees, M., \& Manzoor, S. (2017). Development of new NIR-spectroscopy method combined with multivariate analysis for detection of adulteration in camel milk with goat milk. Food Chemistry, 221, 746-750.

Malegori, C., Nascimento Marques, E. J., de Freitas, S. T., Pimentel, M. F., Pasquini, C., \& Casiraghi, E. (2017). Comparing the analytical performances of Micro-NIR and FT- 
NIR spectrometers in the evaluation of acerola fruit quality, using PLS and SVM regression algorithms. Talanta, 165, 112-116.

Marian, L., \& Thøgersen, J. (2013). Direct and mediated impacts of product and process characteristics on consumers' choice of organic vs. conventional chicken. Food Quality and Preference, 29(2), 106-112.

Markiewicz-Kęszycka, M., Wójtowski, J., Kuczyńska, B., Puppel, K., Czyżak-Runowska, G., Bagnicka, E., Strzałkowska, N., Jóźwik, A., \& Krzyżewski, J. (2013). Chemical composition and whey protein fraction of late lactation mares' milk. International Dairy Journal, 31(2), 62-64.

Martin, B., Cornu, A., Kondjoyan, N., Ferlay, A., Verdier-Metz, I., Pradel, P., Rock, E., Chilliard, Y., Coulon, J., \& Berdagué, J. (2005). Milk indicators for recognizing the types of forages eaten by dairy cows. Indicators of milk and beef quality(112), 127-136.

Molkentin, J. (2009). Authentication of Organic Milk Using $\delta 13 \mathrm{C}$ and the $\alpha$-Linolenic Acid Content of Milk Fat. Journal of Agricultural and Food Chemistry, 57(3), 785-790.

Molkentin, J., \& Giesemann, A. (2007). Differentiation of organically and conventionally produced milk by stable isotope and fatty acid analysis. 388(1), 297-305.

Molkentin, J., \& Giesemann, A. (2010). Follow-up of stable isotope analysis of organic versus conventional milk. 398(3), 1493-1500.

Müller, C. E., \& Gaus, H. (2015). Consumer Response to Negative Media Information About Certified Organic Food Products. Journal of Consumer Policy, 38(4), 387-409.

NEVO. (2019). NEVO-Table, Dutch Food Composition Table.

Nozière, P., Graulet, B., Lucas, A., Martin, B., Grolier, P., \& Doreau, M. (2006). Carotenoids for ruminants: From forages to dairy products. Animal Feed Science and Technology, 131(3), 418-450.

O'Mara, F. P., Fitzgerald, J. J., Murphy, J. J., \& Rath, M. (1998). The effect on milk production of replacing grass silage with maize silage in the diet of dairy cows. Livestock Production Science, 55(1), 79-87.

O’Donnell, A., Spatny, K., Vicini, J., \& Bauman, D. (2010). Survey of the fatty acid composition of retail milk differing in label claims based on production management practices. Journal of Dairy Science, 93(5), 1918-1925.

Padel, S. (2001). Conversion to organic farming: a typical example of the diffusion of an innovation? Sociologia ruralis, 41(1), 40-61.

Pilarczyk, R., Wojcik, J., Sablik, P., \& Czerniak, P. (2015). Fatty acid profile and health lipid indices in the raw milk of Simmental and Holstein-Friesian cows from an organic farm. South African Journal of Animal Science, 45(1), 30-38.

Polderman, N., Cammelbeeck, T., Uitslag, H., \& Gouw, L. d. (2016). Food fraud: consumers' opinions and the identification of authenticity deviations. Consumentenbond. 
Prache, S., Priolo, A., \& Grolier, P. (2003). Persistence of carotenoid pigments in the blood of concentrate-finished grazing sheep: its significance for the traceability of grass-feeding. Journal of Animal Science, 81(2), 360-367.

Prache, S., Priolo, A., Tournadre, H., Jailler, R., Dubroeucq, H., Micol, D., \& Martin, B. (2002). Traceability of grass-feeding by quantifying the signature of carotenoid pigments in herbivores meat, milk and cheese. Multi-fonction grasslands: quality forages, animal products and landscapes, British Grassland Society, La Rochelle, France, 592-593.

Raszap Skorbiansky, S., \& Ferreira, G. C. (2018). Analysis of Fraud Incidents in the US Organic Market.

Rey-Crespo, F., Miranda, M., \& López-Alonso, M. (2013). Essential trace and toxic element concentrations in organic and conventional milk in NW Spain. Food and Chemical Toxicology, 55, 513-518.

Rodríguez-Bermúdez, R., López-Alonso, M., Miranda, M., Fouz, R., Orjales, I., \& HerreroLatorre, C. (2018). Chemometric authentication of the organic status of milk on the basis of trace element content. Food Chemistry, 240, 686-693.

Schmidt, H.-1., Roßmann, A., Voerkelius, S., Schnitzler, W. H., Georgi, M., Graßmann, J., Zimmermann, G., \& Winkler, R. (2005). Isotope characteristics of vegetables and wheat from conventional and organic production. Isotopes in Environmental and Health Studies, 41(3), 223-228.

Schröder, M., Yousefi, F., \& Vetter, W. (2011). Investigating the day-to-day variations of potential marker fatty acids for organic milk in milk from conventionally and organically raised cows. European Food Research and Technology, 232(1), 167-174.

Schwendel, B. H., Morel, P. C. H., Wester, T. J., Tavendale, M. H., Deadman, C., Fong, B., Shadbolt, N. M., Thatcher, A., \& Otter, D. E. (2015). Fatty acid profile differs between organic and conventionally produced cow milk independent of season or milking time. Journal of Dairy Science, 98(3), 1411-1425.

Smigic, N., Djekic, I., Tomasevic, I., Stanisic, N., Nedeljkovic, A., Lukovic, V., \& Miocinovic, J. (2017). Organic and conventional milk - insight on potential differences. British Food Journal, 119(2), 366-376.

Średnicka-Tober, D., Barański, M., Seal, C. J., Sanderson, R., Benbrook, C., Steinshamn, H., Gromadzka-Ostrowska, J., Rembiałkowska, E., Skwarło-Sońta, K., \& Eyre, M. (2016). Higher PUFA and n-3 PUFA, conjugated linoleic acid, $\alpha$-tocopherol and iron, but lower iodine and selenium concentrations in organic milk: a systematic literature review and meta-and redundancy analyses. British Journal of Nutrition, 115(6), 1043-1060.

Thomassen, M. A., van Calker, K. J., Smits, M. C., Iepema, G. L., \& de Boer, I. J. (2008). Life cycle assessment of conventional and organic milk production in the Netherlands. Agricultural Systems, 96(1-3), 95-107. 
Toledo, P., Andrén, A., \& Björck, L. (2002). Composition of raw milk from sustainable production systems. International Dairy Journal, 12(1), 75-80.

Toso, B., Procida, G., \& Stefanon, B. (2002). Determination of volatile compounds in cows' milk using headspace GC-MS. Journal of Dairy Research, 69(4), 569-577.

Tsiafoulis, C. G., Papaemmanouil, C., Alivertis, D., Tzamaloukas, O., Miltiadou, D., Balayssac, S., Malet-Martino, M., \& Gerothanassis, I. P. (2019). NMR-Based Metabolomics of the Lipid Fraction of Organic and Conventional Bovine Milk. Molecules, 24(6), 18.

Tsiplakou, E., Kotrotsios, V., Hadjigeorgiou, I., \& Zervas, G. (2010). Differences in sheep and goats milk fatty acid profile between conventional and organic farming systems. Journal of Dairy Research, 77(3), 343-349.

Tunick, M. H., Paul, M., Ingham, E. R., Karreman, H. J., \& Van Hekken, D. L. (2015). Differences in milk characteristics between a cow herd transitioning to organic versus milk from a conventional dairy herd. International Journal of Dairy Technology, 68(4), 511-518.

Villeneuve, M. P., Lebeuf, Y., Gervais, R., Tremblay, G. F., Vuillemard, J. C., Fortin, J., \& Chouinard, P. Y. (2013). Milk volatile organic compounds and fatty acid profile in cows fed timothy as hay, pasture, or silage. Journal of Dairy Science, 96(11), 7181-7194.

Walstra, P., Wouters, J. T., \& Geurts, T. J. (2005). Dairy science and technology: CRC press.

Weidegang. (2018). Control Plan for Grazing Certificate part A.

Willer, H., Lernoud, J., Huber, B., \& Sahota, A. (2009). The world of organic agriculture.

Willer, H., Schaack, D., \& Lernoud, J. (2019). Organic farming and market development in Europe and the European Union. In The World of Organic Agriculture. Statistics and Emerging Trends 2019, (pp. 217-254): Research Institute of Organic Agriculture FiBL and IFOAM-Organics International.

Yasuko, U., Sadaki, A., Makoto, M., \& Fumiaki, A. (2016). Effect of time at pasture and herbage intake on profile of volatile organic compounds of dairy cow milk. Animal Science Journal, 87(1), 117-125. 


\section{Chapter 2}

\section{Dairy farming system markers: The}

correlation of forage and milk fatty acid profiles from organic, pasture, and conventional systems in the Netherlands

This chapter was published as: Ningjing Liu, Annemieke M. Pustjens, Sara W. Erasmus, Yuzheng Yang, Kasper Hettinga, Saskia M. van Ruth, Dairy farming system markers: The correlation of forage and milk fatty acid profiles from organic, pasture and conventional systems in the Netherlands, Food Chemistry, Volume 213, 2020, 126153. 


\begin{abstract}
The relationships between the fatty acid (FA) composition in forage and milk (F\&M) from different dairy systems were investigated. Eighty milk samples and 91 forage samples were collected from 40 farms (19 organic, 11 pasture, and 10 conventional) in the Netherlands, during winter and summer. The FA profiles of F\&M samples were measured with gas chromatography. The results showed that the F\&M of organic farms were significantly differentiated from the F\&M of other farms, both in summer and winter. The differences are likely due to the different grazing strategies in summer and different forage composition in winter. The Pearson's correlation results showed the specific relationship between individual FAs in forages and related milk. A PLS-DA model was applied to classify all milks samples, resulting in $87.5 \%$ and $83.3 \%$ correct classifications of training set and validation set.
\end{abstract}

Keywords: Classification; Correlation analysis; Fatty acids; Forage; Milk; Organic 


\subsection{Introduction}

Nowadays, there is much interest in organic milk, considering its association with environmental, social, and economic sustainability (Altieri, 2018). The differences of organiclabelled milk and conventional-labelled milk are due to different farming practices. According to the European Commission regulation (EC) No 889/2008: organic cows should graze in organic grassland without limitation; the organic grassland that is provided to cows should not be treated with pesticides and synthetic fertilizers; and roughage should comprise the largest portion of the cow's daily feed intake. Consumers are willing to pay more for these dairy products. In the Netherlands, there is a type of milk called weidemelk, which is pasture milk in English. The farmers that produce this type of milk should allow their cows to graze on outdoor pastures for at least 120 days per year for at least 6 hours per day, but the use of pesticide and synthetic fertilizers are allowed (Liu, Koot, Hettinga, et al., 2018). Dairy companies pay a premium price to the farmers producing pasture milk. However, the price gap between different types of milk makes organic and pasture milk vulnerable to fraudulent practices. To guarantee that the milk is produced according to the regulations, and to protect the rights of stakeholders that obey the regulations, the authenticity of milk should be confirmed.

Recently, various studies have been carried out to determine the differences between organic milk and other types of milk. These studies employed the use of e.g. stable isotope ratios (Chung, Park, Yoon, et al., 2014; Molkentin, 2013), organic volatile compounds (VOCs) (Ueda, Asakuma, Miyaji, et al., 2015; Vasta, D’Alessandro, Priolo, et al., 2012; Villeneuve, Lebeuf, Gervais, et al., 2013), and mineral elements and vitamins (Ellis, Monteiro, Innocent, et al., 2007; Mogensen, Kristensen, Søegaard, et al., 2012; Rey-Crespo, Miranda, \& LópezAlonso, 2013). In addition to these studies, the fatty acid (FA) profiles of organic and other types of milk, especially focusing on the n-3 and n-6 family FAs (van Valenberg, Hettinga, Dijkstra, et al., 2013), have also been investigated (Butler, Nielsen, Slots, et al., 2008; Capuano, van der Veer, Boerrigter-Eenling, et al., 2014; Stergiadis, Leifert, Seal, et al., 2012(Stergiadis, Leifert, Seal, et al., 2012). However, most of the above-mentioned studies just focused on the FA profiles of milk. Research regarding organic feedstuffs and the link between FA profiles of feedstuffs and milks are limited. Hence, it is of value to explore the specific FA profiles in different feedstuffs and to determine if the features in milks and feedstuffs are significantly correlated, especially in uncontrolled conditions as occurs in real life.

Meanwhile, other researchers have focused on the FA metabolism of cows provided with different diets (Adler, Jensen, Thuen, et al., 2013; Leiber, Kreuzer, Nigg, et al., 2005; Willems, Kreuzer, \& Leiber, 2014). The ruminal biohydrogenation and apparent transfer rate of long chain unsaturated FA were shown to be partly dependent on the forages (Buccioni, Decandia, Minieri, et al., 2012; Villalba, Provenza, K Clemensen, et al., 2011). Compared with pasture farms (PFs) and conventional farms (CFs), organic farms (OFs) provide different diet 
profiles to dairy cattle, in terms of forage types and forage ration (Capuano, van der Veer, Boerrigter-Eenling, et al., 2014). Therefore, it would be useful to investigate the correlations between milk FAs and diet FAs in these different dairy production systems. In the Netherlands, the feedstuffs used in dairy farming systems typically consist of forages and concentrates. Forages are produced by the local dairy farms while concentrates are provided by commercial animal feed companies. Farm-produced forages can be divided into fresh forages (herbage) and conserved forages (silage or hay). These forages reflect the features or characteristics of specific farms. The diversity of forages from different farms is relatively high, due to the different types of botany present on different farms, the variation in ratio and quality of raw materials used to make forages, the effect of season, etc. In the Netherlands, the compositions of the silages from OFs, PFs, and CFs are different. Although maize is allowed to be added into organic dairy diets, it is not common that organic dairy farmers provide organic maize to cows. Since the use of pesticides in organic farming is forbidden, the production of organic maize is much lower than conventional maize, leading to a higher price of organic maize. Meanwhile, Dutch organic dairy farmers believe that feeding cows with grass is more natural then feeding them with maize. Due to these economic and ecological reasons, few OFs in the Netherlands used organic maize to produce silage. On the other hand, non-organic farmers use more maize in their cows' diets, since it is known to increase the yields of fat and protein in the milk (Elgersma, Ellen, Van der Horst, et al., 2004), which is directly associated with the milk payments in the Netherlands. Furthermore, OFs provide highest ratio of fresh forages to cows in summer. On the contrary, CFs don't provide any fresh forages to cows both in winter and summer.

Since the difference in forages between dairy production systems may be reflected in milk composition (Martin, Verdier-Metz, Buchin, et al., 2005)., the aim of this study was to determine the relationship between the FA profiles of forage and milk from three different dairy production systems (i.e. organic, pasture, and conventional) in the Netherlands. Since large differences between seasons is expected, samples were collected both in the winter and summer period.

\subsection{Materials and methods}

\subsubsection{Sample collection}

During the European summer and winter period, forage and milk samples were collected from 40 dairy farms in the Netherlands (Table 2.1). The farms were evenly distributed across the country. The winter sample set was obtained from December 2016 to February 2017 and the summer sample set was obtained from July 2017 to August 2017. In the winter, cows from all the systems stayed indoors and were provided with silage. It is because grassland is more fragile in winter and easily damaged if it was over-grazed. In the summer, only organic cows fully grazed because of the low cow density in organic farms, whereas on the pasture farms, grazing was supplemented by other forages. Cows of the conventional farms were only 
provided with silages without access to pasture grazing in the summer. The details of the diets and grazing time for the cows of the different farming systems are shown in Table 1. As there are several factors that may affect the fatty acid profile of herbage during the season (M. Coppa, Farruggia, Ravaglia, et al., 2015; Elgersma, 2015; Revello-Chion, Tabacco, Peiretti, et al., 2011), care was taken to select a time window that is most likely to provide relatively stable samples during the sampling stage. As a result, 80 milk samples and 91 forage samples were collected (Table 1). Milk produced from three subsequent days were temporarily stored in bulk cooling tanks $\left(3^{\circ} \mathrm{C}\right)$ before sampling. Prior to sampling, the milk had been stirred for 10 seconds to ensure that a homogenous sample could be taken. From each farm, a $200 \mathrm{ml}$ milk sample was collected in summer and winter, respectively. Fresh herbages (i.e. fresh forages) were cut at normal harvest heights at six locations within the grazing area of the organic and pasture grasslands. Information on the botanical compositions of the sward was obtained from the farmers. Instead of the bulk silage storage facilities silage samples (i.e. conserved forages) were collected from the stalls directly (500 g from each farm), when they were provided to the cows. The ration composition was reported by the dairy farmers. All the forage samples were stored in tightly sealed plastic bags, to exclude air. The milk and forage samples were stored at $-18^{\circ} \mathrm{C}$ until analysis.

\subsubsection{Forage fat extraction}

A $5.0 \mathrm{~g}$ sample of forage was weighed (to the nearest $0.01 \mathrm{~g}$ ) into a $100 \mathrm{ml}$ conical flask. The sample was then mixed with $4 \mathrm{~g}$ of sodium sulphate, after which $25 \mathrm{ml}$ of a chloroform:methanol mixture $(2: 1, \mathrm{v} / \mathrm{v})$ was added and stirred for $20 \mathrm{~min}$ with a magnetic stirrer. The solution was then filtered into a clean $100 \mathrm{ml}$ conical flask. The extraction was repeated two more times with the chloroform:methanol mixture and the filtrate collected in the same flask. The final filtrate was dried under a stream of nitrogen gas (with a maximum temperature of $45^{\circ} \mathrm{C}$ ).

\subsubsection{Milk fat extraction}

Milk samples $(5 \mathrm{ml})$ were defrosted in a refrigerator overnight at $4^{\circ} \mathrm{C}$. The liquid samples were centrifuged for $10 \mathrm{~min}$ at $2000 \mathrm{~g}$ (Avanti J-25, Beckman Coulter Inc, IN, USA). The resulting top cream layer was collected by spoon and heated in a water bath (Precision GP 20, Thermo Fisher Scientific, MA, USA) for $10 \mathrm{~min}$ at $38^{\circ} \mathrm{C}$, followed by a $10 \mathrm{~min}$ sonication in a ultrasonic bath (Ultrasoon Reiniger 13 L, HBM Machines B.V., Netherlands). The final milk fat extract was obtained after another five-minute centrifugation $(1600 \mathrm{~g})$. 


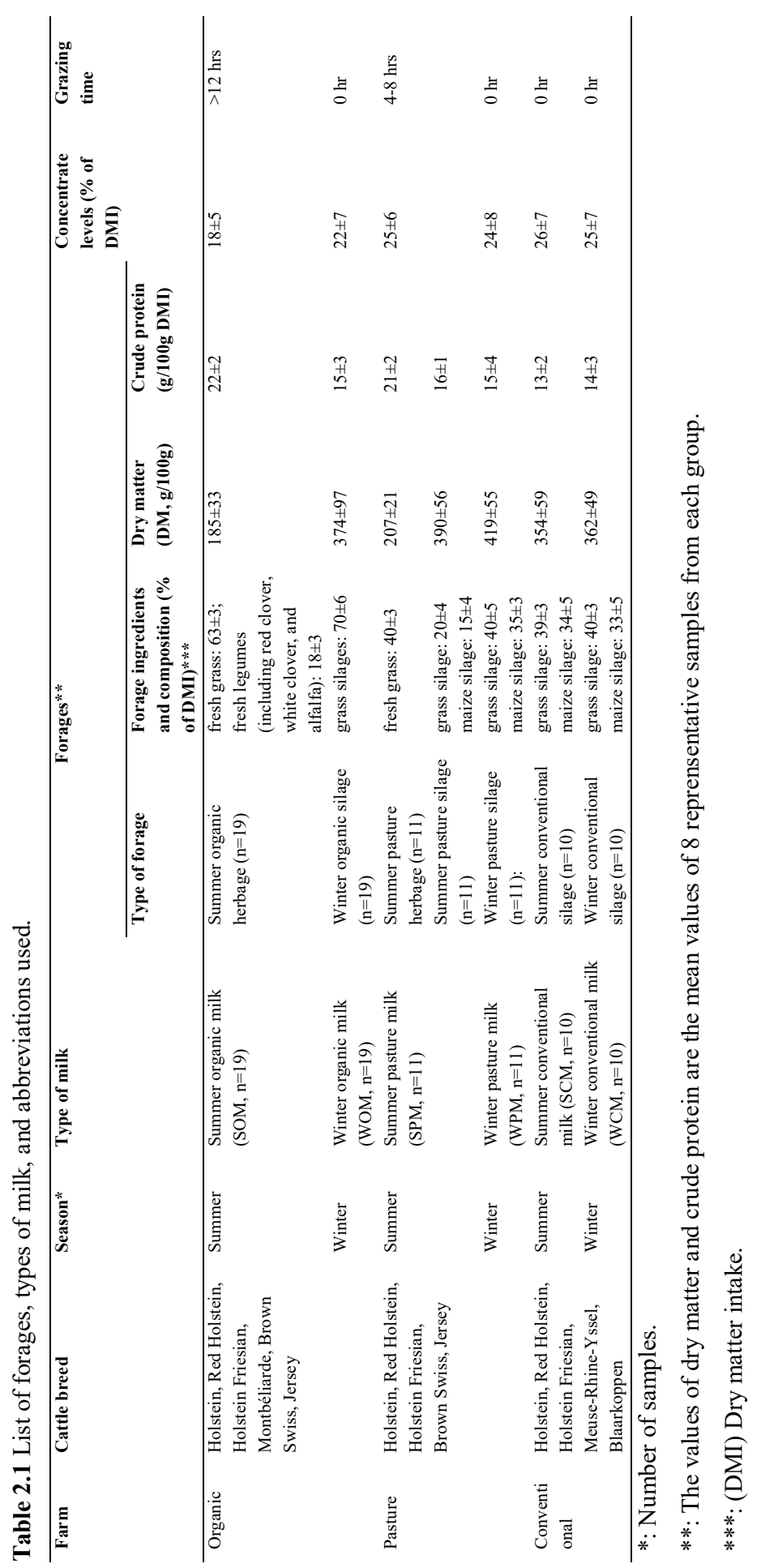




\subsubsection{Fatty acid methyl esters (FAME) analysis}

The fat extracts of the respective forage and milk samples were analysed with a gas chromatograph instrument, GC16958 (Agilent 7890A, Agilent Technologies, Palo Alto, CA, USA), according to NEN-ISO 1740:2004 | IDF 6. The GC was equipped with a $100 \mathrm{~m} \times 0.25$ $\mathrm{mm} \times 0.2 \mu \mathrm{m}$ film thickness fused silica capillary column (Varian, Palo Alto, CA) coupled to a flame ionization detector (temperature: $275^{\circ} \mathrm{C}$ ). Approximately $70 \mathrm{mg}$ of fat was weighted in a $30 \mathrm{ml}$ sterile, screw top plastic bottle, mixed with $5 \mathrm{ml}$ of the internal standard solution: 500 $\mathrm{mg}$ of C13:0 triglyceride and 500 mg of C11:0 FAME in $250 \mathrm{ml}$ tert-butyl methyl ether. For the transesterification step, $5 \mathrm{ml}$ of a methanol sodium methoxide solution $(5 \%, \mathrm{~m} / \mathrm{v})$ was added, followed with the addition of $2 \mathrm{ml}$ hexane and $10 \mathrm{ml}$ neutralization solution after $180 \mathrm{~s}$ and $210 \mathrm{~s}$, respectively. The mixture was then vortexed for $30 \mathrm{~s}$ and centrifuged for $5 \mathrm{~min}$, after which $1 \mathrm{ml}$ of the supernatant was removed with a pipette and transferred to a $1.5 \mathrm{ml} \mathrm{GC}$ amber glass vial with a magnetic crimp cap. Each sample was weighed and measured in duplicate. The concentrations of FAs were expressed as $\mathrm{mg} / 100 \mathrm{mg}$ total fat. Average values of the duplicates were used for data analysis. All samples were analysed in duplicate. All the chemicals that were used were ACS grade, and purchased from Sigma Aldrich (St. Louis, MO, USA). All samples were analysed in duplicate.

\subsubsection{Data analysis}

According to the results of the Shapiro-Wilk test, the absolute FA concentrations, and $\log$ transferred scores, were not normally distributed, which was due to the large variance among farms. The Kruskal-Wallis test was therefore applied to determine if there were any significant differences, at a significance level of $5 \%(\mathrm{P}=0.05)$, between different types of forages (Liu, Parra, et al., 2018). Pairwise comparisons were carried out by the Mann-Whitney U-test to investigate differences in FA levels. In a similar manner, the FA compositions of the milk samples were also analysed using the same tests. To control the false discovery rate (FDR), $\mathrm{P}$ values were adjusted using Benjamini-Hochberg $(\mathrm{BH})$ adjustment (Benjamini \& Hochberg, 1995). Principal component analysis (PCA) was used to visualise relations between samples. To balance the weights of different variables, raw data were auto-scaled before PCA. The correlations between FA profiles of milk and forages were evaluated by calculating Pearson's correlation coefficients (r) (Snedecor \& Cochran, 1980). After the correlation analysis, partial least squares discrimination analysis (PLS-DA) algorithm was applied to build a classification model with $70 \%$ of the milk samples (training set) to discriminate milks from different farming system (organic, pasture, and conventional). The rest $30 \%$ of the milk samples (validation set) was used to validate the model. The performance of the model was evaluated by the overall accuracy. The best pre-processing methods and components number were determined by the results of leave-five-out cross validation. All the statistical analyses were conducted using $\mathrm{R}$ 3.2.3 (R Foundation for Statistical Computing, Vienna, Austria). 


\subsection{Results}

\subsubsection{Fatty acid profiles of forages from the three different production systems}

The FA profile of each forage type is shown in Table 2.2. The dairy production system had a strong effect on the forage FA composition. Only C18:1TFA, C18:4n3, and C20:2n6 did not significantly differ between the production systems $(\mathrm{P}>0.05)$. According to the pairwise comparisons, the FA profiles between fresh forages (herbage) and conserved forages (silage) were significantly different. Compared with summer organic herbages, summer conventional silages and winter silages had lower percentages of $\mathrm{C} 18: 3 \mathrm{n} 3$, and higher percentages of $\mathrm{C} 18: 2 \mathrm{n} 6$ and $\mathrm{C} 16: 0$. In fresh forages (summer organic herbages and summer pasture herbages), the dominant FAs were linolenic acid (C18:3n3), linoleic acid (C18:2n6), and palmitic acid (C16:0). The summer organic herbages had higher concentrations of C16:0 and C18:2n6, and a lower concentration of $\mathrm{C} 18: 3 \mathrm{n} 3$ than the summer pasture herbages. The significant differences between organic and non-organic conserved forages were observed in the proportions of C18:1n9, C18:2n6, C18:3n3, and monounsaturated fatty acids (MUFA) (Table 2.2).

To obtain a better view on the differences between different sample groups, FA compositions of different forages were subjected to PCA and the plots resulting from this are shown in Fig. 2.1. In the summer forage PCA bi-plot (Fig. 2.1a), fresh forages are clearly separated from conserved forages. The dominant FAs that are closely related to fresh forages were C18:3n3 and PUFA, while MUFA, C18:1n9, and C18:2n6 are more associated with conserved forages. Regarding the conserved forages in winter (Fig. 2.1b), organic silage samples are grouped in the middle part of the plot, while conventional silage samples are grouped in the right-hand side of the plot. When combining summer and winter samples (Fig. 2.1c), the winter and summer pasture silages are grouped with the conventional silage samples and with winter organic silage, but share relatively more overlapping area with winter pasture silage and summer conventional silage along PC1 (Fig. 2.1c). The FA C18:1n9 was observed to be an indicator of winter conventional silage in Fig. 2.1b, matching with the result from Table 2.2, which shows a significant higher level of C18:1n9 in winter conventional silage compared to winter organic silage. Compared to Fig. 2.1a, fewer major FAs show clear relations with certain forage groups in Fig. 2.1b, similar to the result from Table 2.2.

Table 2.2 Fatty acid compositions (\%) in summer organic herbage ( $\mathrm{SOH}$ ), summer pasture herbage (SPH), summer pasture silage (SPS), summer conventional silage (SCS), winter organic silage (WOS), winter pasture silage (WPS), and winter conventional silage (WCS): mean concentrations \pm standard deviations and statistical relevance of differences between forages.

\begin{tabular}{|c|c|c|c|c|c|c|c|c|}
\hline \multirow{2}{*}{$\begin{array}{l}\text { Fatty } \\
\text { acids* }\end{array}$} & \multicolumn{4}{|c|}{ Summer** } & \multicolumn{3}{|l|}{ Winter } & \multirow[t]{2}{*}{$P$} \\
\hline & $\begin{array}{l}\text { SOH } \\
(n=19)\end{array}$ & $\begin{array}{l}\text { SPH } \\
(n=11)\end{array}$ & SPS $(n=11)$ & $\begin{array}{l}\text { SCS } \\
(n=10)\end{array}$ & $\begin{array}{l}\text { WOS } \\
(n=19)\end{array}$ & $\begin{array}{l}\text { WPS } \\
(n=11)\end{array}$ & $\begin{array}{l}\text { WCS } \\
(n=10)\end{array}$ & \\
\hline C6:0 & $0.0^{\mathrm{a}} \pm 0.0$ & $0.0^{\mathrm{a}} \pm 0.0$ & $0.1^{\mathrm{ab}} \pm 0.1$ & $0.1^{\mathrm{ab}} \pm 0.1$ & $0.2^{b} \pm 0.2$ & $0.1^{\mathrm{ab}} \pm 0.1$ & $0.1^{\mathrm{ab}} \pm 0.1$ & $<0.01$ \\
\hline
\end{tabular}




\begin{tabular}{|c|c|c|c|c|c|c|c|c|}
\hline \multirow{2}{*}{$\begin{array}{l}\text { Fatty } \\
\text { acids* }\end{array}$} & \multicolumn{4}{|c|}{ Summer** } & \multicolumn{3}{|l|}{ Winter } & \multirow[t]{2}{*}{$P$} \\
\hline & $\begin{array}{l}\text { SOH } \\
(n=19)\end{array}$ & $\begin{array}{l}\text { SPH } \\
(n=11)\end{array}$ & SPS $(n=11)$ & $\begin{array}{l}\text { SCS } \\
(n=10)\end{array}$ & $\begin{array}{l}\text { WOS } \\
(n=19)\end{array}$ & $\begin{array}{l}\text { WPS } \\
(n=11)\end{array}$ & $\begin{array}{l}\text { WCS } \\
(n=10)\end{array}$ & \\
\hline C10:0 & $0.1^{\mathrm{a}} \pm 0.0$ & $0.1^{\mathrm{a}} \pm 0.0$ & $0.1^{\mathrm{a}} \pm 0.1$ & $0.2^{\mathrm{a}} \pm 0.2$ & $0.2^{\mathrm{a}} \pm 0.1$ & $0.1^{\mathrm{a}} \pm 0.1$ & $0.2^{\mathrm{a}} \pm 0.2$ & $<0.05$ \\
\hline C12:0 & $0.2^{\mathrm{a}} \pm 0.1$ & $0.2^{\mathrm{ab}} \pm 0.0$ & $0.4^{\mathrm{b}} \pm 0.2$ & $1.4^{\mathrm{c}} \pm 2.2$ & $0.4^{\mathrm{bc}} \pm 0.2$ & $0.4^{\mathrm{b}} \pm 0.2$ & $1.4^{\mathrm{abc}} \pm 2.2$ & $<0.01$ \\
\hline C14:0 & $0.4^{\mathrm{a}} \pm 0.1$ & $0.3^{\mathrm{a}} \pm 0.1$ & $0.5^{\mathrm{ab}} \pm 0.2$ & $0.7^{\mathrm{ab}} \pm 0.7$ & $0.7^{\mathrm{b}} \pm 0.2$ & $0.5^{\mathrm{ab}} \pm 0.2$ & $0.7^{\mathrm{ab}} \pm 0.7$ & $<0.01$ \\
\hline C15:0 & $0.2^{\mathrm{a}} \pm 0.0$ & $0.1^{\mathrm{a}} \pm 0.0$ & $0.2^{\mathrm{b}} \pm 0.1$ & $0.1^{\mathrm{a}} \pm 0.1$ & $0.4^{\mathrm{b}} \pm 0.2$ & $0.2^{\mathrm{a}} \pm 0.1$ & $0.1^{\mathrm{a}} \pm 0.1$ & $<0.01$ \\
\hline $\mathrm{C} 16: 0$ & $17.1^{\mathrm{b}} \pm 1.1$ & $15.3^{\mathrm{a}} \pm 1.0$ & $13.5^{\mathrm{a}} \pm 2.0$ & $12.7^{\mathrm{a}} \pm 3.0$ & $14.0^{\mathrm{a}} \pm 1.5$ & $13.2^{\mathrm{a}} \pm 2.2$ & $13.0^{\mathrm{a}} \pm 3.1$ & $<0.01$ \\
\hline $\mathrm{C} 16: 1 n 7$ & $3.2^{\mathrm{c}} \pm 0.2$ & $3.0^{\mathrm{c}} \pm 0.3$ & $1.5^{\mathrm{ab}} \pm 0.6$ & $0.9^{\mathrm{a}} \pm 0.3$ & $2.0^{\mathrm{b}} \pm 0.2$ & $1.6^{\mathrm{ab}} \pm 0.5$ & $1.0^{\mathrm{a}} \pm 0.4$ & $<0.01$ \\
\hline C17:0 & $0.2^{\mathrm{b}} \pm 0.0$ & $0.2^{\mathrm{ab}} \pm 0.01$ & $0.2^{\mathrm{b}} \pm 0.0$ & $0.1^{\mathrm{ab}} \pm 0.1$ & $0.2^{\mathrm{ab}} \pm 0.1$ & $0.2^{\mathrm{ab}} \pm 0.0$ & $0.1^{\mathrm{a}} \pm 0.0$ & $<0.01$ \\
\hline C18:0 & $2.0^{\mathrm{b}} \pm 0.2$ & $1.5^{\mathrm{a}} \pm 0.2$ & $1.8^{\mathrm{ab}} \pm 0.5$ & $1.9^{\mathrm{ab}} \pm 0.3$ & $2.0^{\mathrm{ab}} \pm 0.5$ & $1.8^{\mathrm{ab}} \pm 0.4$ & $2.0^{\mathrm{ab}} \pm 0.9$ & $<0.01$ \\
\hline C18:1TFA & $0.0^{\mathrm{a}} \pm 0.0$ & $0.1^{\mathrm{a}} \pm 0.1$ & $0.2^{\mathrm{a}} \pm 0.2$ & $0.09^{\mathrm{a}} \pm 0.1$ & $0.32^{\mathrm{a}} \pm 0.1$ & $0.1^{\mathrm{a}} \pm 0.2$ & $0.1^{\mathrm{a}} \pm 0.1$ & \\
\hline $\mathrm{C} 18: 1 n 9$ & $2.7^{\mathrm{a}} \pm 0.4$ & $2.2^{\mathrm{a}} \pm 0.6$ & $8.1^{b c} \pm 4.77$ & $15.3^{\mathrm{c}} \pm 6.1$ & $5.7^{\mathrm{b}} \pm 3.0$ & $10.2^{\mathrm{bc}} \pm 6.6$ & $13.9^{c} \pm 4.6$ & $<0.01$ \\
\hline C18:2TFA & $0.0^{\mathrm{a}} \pm 0.0$ & $0.1^{\mathrm{a}} \pm 0.0$ & $0.1^{\mathrm{a}} \pm 0.1$ & $0.1^{\mathrm{a}} \pm 0.2$ & $0.2^{\mathrm{a}} \pm 0.4$ & $0.1^{\mathrm{a}} \pm 0.1$ & $0.1^{\mathrm{a}} \pm 0.1$ & $<0.05$ \\
\hline C18:2n6 & $14.1^{b_{ \pm}} \pm 0.9$ & $12.2^{\mathrm{a}} \pm 1.2$ & $24.2^{\mathrm{cd}} \pm 7.1$ & $33.3^{\mathrm{d}_{1}} \pm 9.0$ & $19.4^{\mathrm{c}} \pm 5.1$ & $25.4^{\mathrm{cd}} \pm 7.0$ & $33.5^{\mathrm{d}} \pm 10.4$ & $<0.01$ \\
\hline $\mathrm{C} 18: 3 n 3$ & $53.1^{\mathrm{c}} \pm 2.8$ & $58.2^{\mathrm{d}} \pm 3.8$ & $40.1^{\mathrm{bc}} \pm 10.8$ & $25.8^{\mathrm{a}} \pm 11.4$ & $42.6^{\mathrm{b}} \pm 7.8$ & $36.9^{\mathrm{ab}} \pm 9.4$ & $26.3^{\mathrm{a}} \pm 11.8$ & $<0.01$ \\
\hline C18:3TFA & $0.3^{b} \pm 0.1$ & $0.3^{\mathrm{b}} \pm 0.0$ & $0.2^{\mathrm{ab}} \pm 0.1$ & $0.1^{\mathrm{a}} \pm 0.1$ & $0.3^{\mathrm{ab}} \pm 0.2$ & $0.3^{\mathrm{ab}} \pm 0.1$ & $0.2^{\mathrm{a}} \pm 0.1$ & $<0.01$ \\
\hline $\mathrm{C} 18: 4 n 3$ & $0.1^{\mathrm{a}} \pm 0.1$ & $0.1^{\mathrm{a}} \pm 0.1$ & $0.1^{\mathrm{a}} \pm 0.1$ & $0.1^{\mathrm{a}} \pm 0.2$ & $0.2^{\mathrm{a}} \pm 0.2$ & $0.1^{\mathrm{a}} \pm 0.1$ & $0.1^{\mathrm{a}} \pm 0.2$ & \\
\hline C19:0 & $0.3^{b} \pm 0.1$ & $0.2^{\mathrm{a}} \pm 0.1$ & $0.2^{\mathrm{ab}} \pm 0.3$ & $0.3^{\mathrm{ab}} \pm 0.3$ & $0.2^{\mathrm{ab}} \pm 0.2$ & $0.2^{\mathrm{ab}} \pm 0.3$ & $0.3^{\mathrm{ab}} \pm 0.2$ & $<0.05$ \\
\hline C20:0 & $0.3^{\mathrm{b}} \pm 0.1$ & $0.2^{\mathrm{a}} \pm 0.1$ & $0.4^{\mathrm{bc}} \pm 0.2$ & $0.4^{\mathrm{cd}} \pm 0.1$ & $0.5^{\mathrm{abc}} \pm 0.3$ & $0.4^{\mathrm{c}} \pm 0.1$ & $0.4^{\mathrm{bc}} \pm 0.1$ & $<0.01$ \\
\hline $\mathrm{C} 20: 2 n 6$ & $0.0^{\mathrm{a}} \pm 0.0$ & $0.0^{\mathrm{a}} \pm 0.0$ & $0.0^{\mathrm{a}} \pm 0.0$ & $0.0^{\mathrm{a}} \pm 0.0 \mathrm{a}$ & $0.0^{\mathrm{a}} \pm 0.0$ & $0.0^{\mathrm{a}} \pm 0.0$ & $0.0^{\mathrm{a}} \pm 0.0$ & \\
\hline $\mathrm{C} 20: 3 n 3$ & $0.1^{\mathrm{a}} \pm 0.1$ & $0.1^{\mathrm{ab}} \pm 0.2$ & $0.1^{\mathrm{ab}} \pm 0.2$ & $0.1^{\mathrm{ab}} \pm 0.1$ & $0.3^{b} \pm 0.2$ & $0.2^{\mathrm{ab}} \pm 0.1$ & $0.1^{\mathrm{ab}} \pm 0.1$ & $<0.01$ \\
\hline $\mathrm{C} 20: 4 n 6$ & $0.7^{\mathrm{a}} \pm 0.2$ & $0.6^{\mathrm{a}} \pm 0.2$ & $0.2^{\mathrm{a}} \pm 0.5$ & $0.3^{\mathrm{a}} \pm 0.3$ & $1.0^{\mathrm{a}} \pm 0.9$ & $0.7^{\mathrm{a}} \pm 0.7$ & $0.5^{\mathrm{a}} \pm 0.4$ & $<0.01$ \\
\hline C22:0 & $0.7^{b} \pm 0.1$ & $0.6^{\mathrm{b}} \pm 0.1$ & $0.6^{\mathrm{ab}} \pm 0.2$ & $0.4^{\mathrm{a}} \pm 0.1$ & $0.7^{b} \pm 0.3$ & $0.6^{\mathrm{ab}} \pm 0.2$ & $0.4^{\mathrm{a}} \pm 0.1$ & $<0.01$ \\
\hline $\mathrm{C} 24: 0$ & $0.6^{\mathrm{c}} \pm 0.1$ & $0.4^{\mathrm{b}} \pm 0.1$ & $0.4^{\mathrm{ab}} \pm 0.2$ & $0.3^{\mathrm{a}} \pm 0.1$ & $0.5^{b c} \pm 0.12$ & $0.4^{\mathrm{ab}} \pm 0.1$ & $0.3^{\mathrm{ab}} \pm 0.1$ & $<0.01$ \\
\hline CLA & $0.2^{\mathrm{a}} \pm 0.3$ & $0.1^{\mathrm{a}} \pm 0.2$ & $2.5^{\mathrm{b}} \pm 1.0$ & $1.9^{\mathrm{b}} \pm 1.2$ & $2.8^{\mathrm{b}} \pm 1.6$ & $2.2^{\mathrm{b}} \pm 1.1$ & $2.09^{b} \pm 1.2$ & $<0.01$ \\
\hline SFA & $21.9^{\mathrm{b}} \pm 1.6$ & $18.9^{\mathrm{a}} \pm 1.5$ & $18.4^{\mathrm{a}} \pm 2.5$ & $18.5^{\mathrm{ab}} \pm 3.7$ & $20.1^{\mathrm{ab}} \pm 2.5$ & $18.2^{\mathrm{a}} \pm 2.5$ & $19.1^{\mathrm{ab}} \pm 4.0$ & $<0.01$ \\
\hline MUFA & $6.0^{\mathrm{ab}} \pm 0.4$ & $5.6^{\mathrm{a}} \pm 0.7$ & $9.8^{\mathrm{abc}_{ \pm}}+4.3$ & $16.3^{\mathrm{c}} \pm 5.6$ & $8.0^{b} \pm 3.1$ & $12.0^{\mathrm{bc}} \pm 6.5$ & $15.0^{\mathrm{c}} \pm 4.4$ & $<0.01$ \\
\hline PUFA & $68.5^{b} \pm 1.9$ & $71.8^{\mathrm{b}} \pm 2.7$ & $67.6^{\mathrm{ab}} \pm 4.1$ & $61.6^{\mathrm{a}} \pm 5.1$ & $66.9^{\mathrm{ab}} \pm 4.4$ & $65.8^{\mathrm{ab}} \pm 5.0$ & $62.8^{a} \pm 5.2$ & $<0.01$ \\
\hline
\end{tabular}

*: (TFA) Trans fatty acid; (CLA). Conjugated linoleic acids: cis-9, trans-11 C18:2; (SFA); Saturated fatty acid; (MUFA); Monounsaturated fatty acid (PUFA); Polyunsaturated fatty acid.

**: ${ }^{\mathrm{a}-\mathrm{d}}$ Data with different superscript letters are significantly different $(\mathrm{P}<0.05)$ according to the MannWhitney U-test. 
a

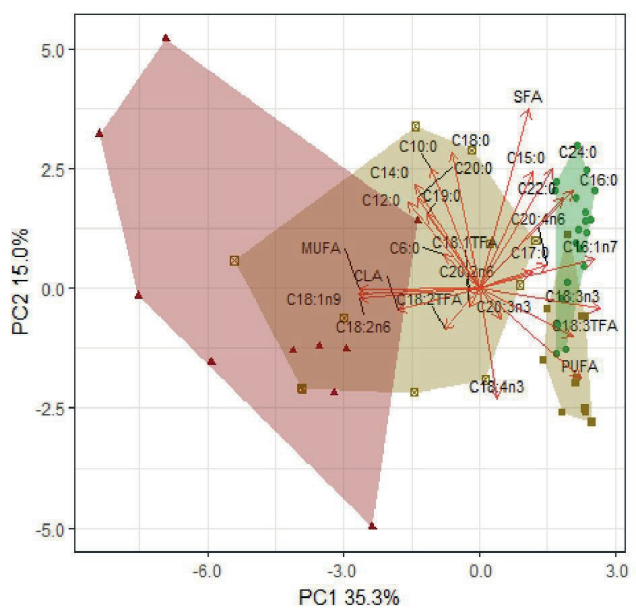

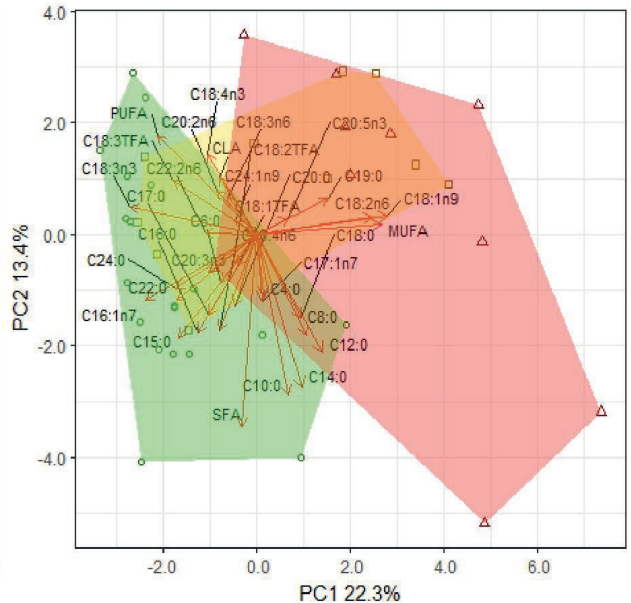

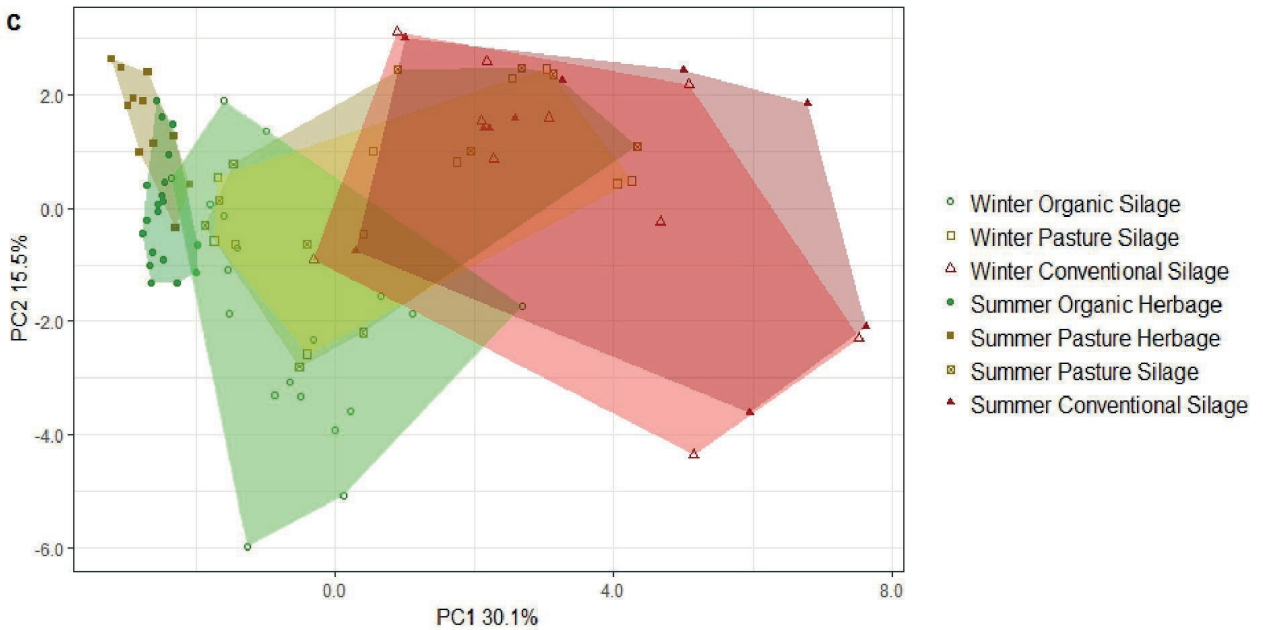

Fig. 2.1. Principal component analysis (PCA) score and loadings plots of the first two principal components of the fatty acid compositions of different forages obtained from the European summer and winter periods: (a) summer forages PCA biplot; (b) winter forages PCA biplot; (c) overall forages PCA scores plot.

\subsubsection{The fatty acid profiles of milk from the three production systems}

Table 2.3 lists the FA profiles of the different milk samples collected in the summer and winter periods. Regarding the predominant FAs, summer organic milk had a significantly lower concentration of $\mathrm{C} 16: 0$ than other types of milk. The concentrations of C16:0 in winter milk 
(including organic, pasture, and conventional) were stable, and were also similar to the concentrations of C16:0 in summer conventional milk. Another abundant FA in the milk was C18:1n9, ranging from $\sim 18 \%$ to $\sim 21 \%$ (Table 2.3 ). The proportions of $\mathrm{C} 18: \ln 9$ in summer organic milk was the highest, followed by summer pasture milk, while the concentrations in other types of milk were the lowest (Table 2.3). Table 2.3 also shows that the concentrations of conjugated linoleic acid (CLA) was significantly higher in summer organic milk compared to the other types of milk. Total saturated and polyunsaturated fatty acids (SFA and PUFA, respectively) were more stable between summer and winter in the pasture and conventional milk compared to the organic milk. An overview of the differences between different types of milk and related FAs is shown in Fig. 2.2 by PCA. The overlapping area of summer milk (Fig. 2.2a) is larger than the overlapping area of winter milk (Fig. 2.2b), which suggests that there were greater differences between organic, pasture, and conventional milk in the winter. In fact, the organic milk was more separated from the conventional milk in winter than in summer, as shown in Fig. 2.2a and b. In Fig. 2.2a, C18:1n9, PUFA, C18:3n3, and CLA all strongly associated with summer organic milk, while C18:2n6, PUFA, C18:3n3, and CLA associated with winter organic milk in Fig. 2.2b. With the majority of differentiating FAs being the same in summer and winter, there is actually quite a good overlap between summer samples and winter samples, even though they are not identical. Overall the milk FA profiles shown a clear difference between both production system and season.

Table 2.3 The means ( \pm standard deviations) of the fatty acid compositions (\%) of summer organic milk (SOM), summer pasture milk (SPM), summer conventional milk (SCM), winter organic milk (WOM), winter pasture milk (WPM), and winter conventional milk (WCM).

\begin{tabular}{|c|c|c|c|c|c|c|c|}
\hline \multirow{2}{*}{$\begin{array}{l}\text { Fatty } \\
\text { acids }\end{array}$} & \multicolumn{3}{|l|}{ Summer } & \multicolumn{3}{|l|}{ Winter } & \multirow{2}{*}{$\mathbf{P}$} \\
\hline & $\begin{array}{l}\text { SOM } \\
(n=19)\end{array}$ & $\operatorname{SPM}(n=11)$ & $\operatorname{SCM}(n=10)$ & $\begin{array}{l}\text { WOM } \\
(n=19)\end{array}$ & $\begin{array}{l}\text { WPM } \\
(n=11)\end{array}$ & $\begin{array}{l}\text { WCM } \\
(n=10)\end{array}$ & \\
\hline C $4: 0$ & $2.6^{\mathrm{a}} \pm 0.2$ & $2.5^{\mathrm{a}} \pm 0.1$ & $2.6^{\mathrm{a}} \pm 0.2$ & $2.5^{\mathrm{a}} \pm 0.2$ & $2.3^{\mathrm{a}} \pm 0.3$ & $2.4^{\mathrm{a}} \pm 0.2$ & $<0.05$ \\
\hline C $6: 0$ & $2.0^{\mathrm{a}} \pm 0.1$ & $2.0^{\mathrm{a}} \pm 0.1$ & $2.0^{\mathrm{a}} \pm 0.1$ & $2.0^{\mathrm{a}} \pm 0.1$ & $2.0^{\mathrm{a}} \pm 0.1$ & $2.0^{\mathrm{a}} \pm 0.1$ & \\
\hline C 8:0 & $1.3^{\mathrm{a}} \pm 0.1$ & $1.2^{\mathrm{a}} \pm 0.0$ & $1.2^{\mathrm{a}} \pm 0.1$ & $1.3^{\mathrm{a}} \pm 0.1$ & $1.2^{\mathrm{a}} \pm 0.1$ & $1.3^{\mathrm{a}} \pm 0.1$ & \\
\hline C10:0 & $2.8^{\mathrm{a}} \pm 0.3$ & $2.9^{\mathrm{a}} \pm 0.1$ & $2.9^{\mathrm{a}} \pm 0.4$ & $3.0^{\mathrm{a}} \pm 0.3$ & $2.9^{\mathrm{a}} \pm 0.2$ & $3.1^{\mathrm{a}} \pm 0.2$ & \\
\hline C12:0 & $3.2^{\mathrm{a}} \pm 0.4$ & $3.9^{\mathrm{b}} \pm 0.2$ & $3.6^{\mathrm{ab}} \pm 0.5$ & $3.5^{\mathrm{ab}} \pm 0.4$ & $3.8^{\mathrm{ab}} \pm 0.4$ & $3.9^{\mathrm{ab}} \pm 0.6$ & $<0.01$ \\
\hline C14:0 & $10.7^{\mathrm{a}} \pm 0.7$ & $11.4^{\mathrm{ab}} \pm 0.5$ & $10.9^{\mathrm{ab}} \pm 0.9$ & $11.7^{\mathrm{ab}} \pm 0.5$ & $11.3^{\mathrm{ab}} \pm 0.6$ & $11.3^{\mathrm{ab}} \pm 0.4$ & $<0.01$ \\
\hline C14:1 & $1.0^{\mathrm{a}} \pm 0.1$ & $1.1^{\mathrm{a}} \pm 0.1$ & $1.0^{\mathrm{a}} \pm 0.1$ & $0.9^{\mathrm{a}} \pm 0.4$ & $1.1^{\mathrm{a}} \pm 0.4$ & $1.5^{\mathrm{a}} \pm 0.5$ & $<0.01$ \\
\hline C15:0 & $1.7^{\mathrm{b}} \pm 0.2$ & $1.6^{\mathrm{ab}} \pm 0.2$ & $1.4^{\mathrm{a}} \pm 0.2$ & $1.5^{\mathrm{ab}} \pm 0.4$ & $1.8^{\mathrm{b} \pm} 0.2$ & $1 \mathrm{ab}_{ \pm 0.2}$ & $<0.01$ \\
\hline C16:0 & $26.7^{\mathrm{a}} \pm 1.7$ & $29.4^{\mathrm{ab}} \pm 2.2$ & $32.3^{\mathrm{b}} \pm 2.7$ & $31.6^{\mathrm{b}} \pm 2.7$ & $31.7^{\mathrm{b} \pm} 2.4$ & $31.2^{\mathrm{b}} \pm 2.3$ & $<0.01$ \\
\hline $\mathrm{C} 16: 1 n 7$ & $3.4^{\mathrm{a}} \pm 0.5$ & $3.7^{\mathrm{a}} \pm 0.7$ & $3.9^{\mathrm{a}} \pm 0.6$ & $3.3^{\mathrm{a}} \pm 1.0$ & $3.8^{\mathrm{a}} \pm 1.1$ & $4.1^{\mathrm{a}} \pm 1.3$ & \\
\hline C17:0 & $0.7^{\mathrm{b}} \pm 0.0$ & $0.7^{\mathrm{ab}} \pm 0.1$ & $0.6^{\mathrm{ab}} \pm 0.1$ & $0.7^{\mathrm{ab}} \pm 0.1$ & $0.7^{\mathrm{ab}} \pm 0.1$ & $0.6^{\mathrm{a}} \pm 0.0$ & $<0.01$ \\
\hline
\end{tabular}




\begin{tabular}{|c|c|c|c|c|c|c|c|}
\hline \multirow{2}{*}{$\begin{array}{l}\text { Fatty } \\
\text { acids }\end{array}$} & \multicolumn{3}{|l|}{ Summer } & \multicolumn{3}{|l|}{ Winter } & \multirow{2}{*}{$\mathbf{P}$} \\
\hline & $\begin{array}{l}\text { SOM } \\
(n=19)\end{array}$ & $\operatorname{SPM}(n=11)$ & $\operatorname{SCM}(n=10)$ & $\begin{array}{l}\text { WOM } \\
(n=19)\end{array}$ & $\begin{array}{l}\text { WPM } \\
(n=11)\end{array}$ & $\begin{array}{l}\text { WCM } \\
(n=10)\end{array}$ & \\
\hline $\mathrm{C} 17: 1 n 7$ & $0.3^{\mathrm{ab}} \pm 0.1$ & $0.3^{\mathrm{ab}} \pm 0.1$ & $0.3^{\mathrm{a}} \pm 0.0$ & $0.4^{\mathrm{b}} \pm 0.1$ & $0.3^{\mathrm{ab}} \pm 0.1$ & $0.3^{\mathrm{ab}} \pm 0.1$ & $<0.01$ \\
\hline C18:0 & $12.6^{\mathrm{b}} \pm 2.0$ & $10.8^{\mathrm{ab}} \pm 2.0$ & $9.8^{\mathrm{a}} \pm 1.8$ & $10.7^{\mathrm{ab}} \pm 1.6$ & $9.7^{\mathrm{a}} \pm 1.3$ & $9.5^{\mathrm{ab}} \pm 1.6$ & $<0.01$ \\
\hline $\mathrm{C} 18: \ln 9$ & $21.4^{\mathrm{c}} \pm 1.5$ & $20.3^{\mathrm{bc}} \pm 1.2$ & $19.9^{\mathrm{b}} \pm 1.6$ & $17.7^{a} \pm 2.0$ & $18.2^{\mathrm{ab}} \pm 2.2$ & $17.5^{\mathrm{ab}} \pm 1.6$ & $<0.01$ \\
\hline $\begin{array}{l}\text { C18:2TF } \\
\text { A }\end{array}$ & $0.9^{\mathrm{b}} \pm 0.2$ & $0.8^{\mathrm{ab}} \pm 0.2$ & $0.6^{\mathrm{a}} \pm 0.2$ & $0.5^{\mathrm{a}} \pm 0.2$ & $0.6^{\mathrm{a}} \pm 0.1$ & $0.5^{\mathrm{a}} \pm 0.2$ & $<0.01$ \\
\hline C18:2n6 & $1.5^{\mathrm{ab}} \pm 0.4$ & $1.2^{\mathrm{a}} \pm 0.1$ & $1.6^{\mathrm{b}} \pm 0.2$ & $1.5^{\mathrm{ab}} \pm 0.4$ & $1.1^{\mathrm{a}} \pm 0.4$ & $1.4^{\mathrm{ab}} \pm 0.6$ & $<0.01$ \\
\hline $\mathrm{C} 18: 3 n 3$ & $0.8^{\mathrm{b}} \pm 0.2$ & $0.5^{\mathrm{a}} \pm 0.1$ & $0.4^{\mathrm{a}} \pm 0.1$ & $0.7^{\mathrm{ab}} \pm 0.2$ & $0.5^{\mathrm{a}} \pm 0.1$ & $0.5^{\mathrm{ab}} \pm 0.2$ & $<0.01$ \\
\hline $\begin{array}{l}\text { C18:3TF } \\
\text { A }\end{array}$ & $0.3^{\mathrm{a}} \pm 0.1$ & $0.3^{\mathrm{a}} \pm 0.1$ & $0.3^{\mathrm{a}} \pm 0.4$ & $0.4^{\mathrm{a}} \pm 0.1$ & $0.4^{\mathrm{a}} \pm 0.1$ & $0.4^{\mathrm{a}} \pm 0.1$ & \\
\hline $\mathrm{C} 18: 3 n 6$ & $0.2^{\mathrm{b}} \pm 0.0$ & $0.1^{\mathrm{ab}} \pm 0.0$ & $0.1^{\mathrm{a}} \pm 0.0$ & $0.2^{\mathrm{ab}} \pm 0.0$ & $0.2^{\mathrm{ab}} \pm 0.0$ & $0.2^{\mathrm{ab}} \pm 0.0$ & $<0.05$ \\
\hline $\mathrm{C} 18: 4 n 3$ & $0.0^{\mathrm{a}} \pm 0.0$ & $0.0^{\mathrm{a}} \pm 0.0$ & $0.0^{\mathrm{a}} \pm 0.0$ & $0.0^{\mathrm{a}} \pm 0.0$ & $0.0^{\mathrm{a}} \pm 0.0$ & $0.0^{\mathrm{a}} \pm 0.0$ & \\
\hline C19:0 & $0.5^{\mathrm{b}} \pm 0.1$ & $0.4^{\mathrm{ab}} \pm 0.1$ & $0.4^{\mathrm{a}} \pm 0.1$ & $0.4^{\mathrm{a}} \pm 0.1$ & $0.4^{\mathrm{a}} \pm 0.1$ & $0.4^{\mathrm{ab}} \pm 0.1$ & $<0.01$ \\
\hline $\mathrm{C} 20: 0$ & $0.2^{\mathrm{a}} \pm 0.0$ & $0.1^{\mathrm{a}} \pm 0.0$ & $0.1^{\mathrm{a}} \pm 0.0$ & $0.2^{\mathrm{a}} \pm 0.0$ & $0.1^{\mathrm{a}} \pm 0.0$ & $0.1^{\mathrm{a}} \pm 0.0$ & \\
\hline $\mathrm{C} 20: 2 n 6$ & $0.0^{\mathrm{a}} \pm 0.1$ & $0.0^{\mathrm{a}} \pm 0.0$ & $0.0^{\mathrm{a}} \pm 0.0$ & $0.0^{\mathrm{a}} \pm 0.0$ & $0.0^{\mathrm{a}} \pm 0.0$ & $0.0^{\mathrm{a}} \pm 0.0$ & \\
\hline $\mathrm{C} 20: 3 n 6$ & $0.0^{\mathrm{a}} \pm 0.0$ & $0.1^{\mathrm{a}} \pm 0.0$ & $0.1^{\mathrm{a}} \pm 0.0$ & $0.1^{\mathrm{a}} \pm 0.0$ & $0.0^{\mathrm{a}} \pm 0.0$ & $0.1^{\mathrm{a}} \pm 0.0$ & \\
\hline $\mathrm{C} 20: 3 n 3$ & $0.0^{\mathrm{a}} \pm 0.0$ & $0.0^{\mathrm{a}} \pm 0.0$ & $0.0^{\mathrm{a}} \pm 0.0$ & $0.0^{\mathrm{a}} \pm 0.0$ & $0.0^{\mathrm{a}} \pm 0.0$ & $0.0^{\mathrm{a}} \pm 0.0$ & \\
\hline $\mathrm{C} 20: 4 n 6$ & $0.1^{\mathrm{a}} \pm 0.0$ & $0.1^{\mathrm{a}} \pm 0.0$ & $0.1^{\mathrm{a}} \pm 0.0$ & $0.1^{\mathrm{a}} \pm 0.0$ & $0.1^{\mathrm{a}} \pm 0.0$ & $0.1^{\mathrm{a}} \pm 0.0$ & $<0.05$ \\
\hline $\mathrm{C} 20: 5 n 3$ & $0.1^{\mathrm{b}} \pm 0.0$ & $0.1^{\mathrm{a}} \pm 0.0$ & $0.0^{\mathrm{a}} \pm 0.0$ & $0.1^{\mathrm{ab}} \pm 0.0$ & $0.1^{\mathrm{a}} \pm 0.0$ & $0.1^{\mathrm{a}} \pm 0.0$ & $<0.01$ \\
\hline C22:0 & $0.1^{\mathrm{b}} \pm 0.0$ & $0.1^{\mathrm{a}} \pm 0.0$ & $0.1^{\mathrm{a}} \pm 0.0$ & $0.1^{\mathrm{ab}} \pm 0.0$ & $0.1^{\mathrm{a}} \pm 0.0$ & $0.1^{\mathrm{a}} \pm 0.0$ & $<0.01$ \\
\hline $\mathrm{C} 22: 2 n 6$ & $0.0^{\mathrm{bc}} \pm 0.0$ & $0.1^{\mathrm{c}} \pm 0.0$ & $0.0^{\mathrm{abc}} \pm 0.0$ & $0.0^{\mathrm{abc}_{ \pm}} \pm 0.0$ & $0.0^{\mathrm{a}} \pm 0.0$ & $0.0^{\mathrm{ab}} \pm 0.0$ & $<0.01$ \\
\hline C24:0 & $0.1^{\mathrm{a}} \pm 0.0$ & $0.0^{\mathrm{ab}} \pm 0.0$ & $0.0^{\mathrm{b}} \pm 0.0$ & $0.0^{\mathrm{ab}} \pm 0.0$ & $0.0^{\mathrm{ab}} \pm 0.0$ & $0.0^{\mathrm{ab}} \pm 0.0$ & $<0.01$ \\
\hline CLA & $1.1^{\mathrm{c}} \pm 0.2$ & $0.7^{\mathrm{b}} \pm 0.1$ & $0.4^{\mathrm{a}} \pm 0.1$ & $0.5^{\mathrm{ab}} \pm 0.1$ & $0.4^{\mathrm{a}} \pm 0.1$ & $0.4^{\mathrm{a}} \pm 0.1$ & $<0.01$ \\
\hline SFA & $65.2^{\mathrm{a}} \pm 2.1$ & $67.1^{\mathrm{ab}} \pm 0.9$ & $67.9^{\mathrm{abc}} \pm 1.7$ & $70.0^{\mathrm{c}} \pm 2.37$ & $69.1^{\mathrm{bc}} \pm 2.5$ & $69.1^{\mathrm{abc}_{ \pm}}+3.0$ & $<0.01$ \\
\hline MUFA & $26.57^{\mathrm{b}} \pm 1.55$ & $26.58^{\mathrm{b}} \pm 2.01$ & $25.92^{\mathrm{b}} \pm 1.47$ & $21.6^{a} \pm 2.3$ & $22.5^{a} \pm 2.2$ & $22.4^{a} \pm 1.8$ & $<0.01$ \\
\hline PUFA & $4.9^{\mathrm{b}} \pm 0.5$ & $3.9^{\mathrm{a}} \pm 0.5$ & $3.8^{\mathrm{a}} \pm 0.418$ & $4.0^{\mathrm{ab}} \pm 0.8$ & $3.4^{\mathrm{a}} \pm 0.5$ & $3.6^{\mathrm{a}} \pm 1.2$ & $<0.01$ \\
\hline
\end{tabular}

(SOM) Summer organic milk; (SPM) Summer pasture milk; (SCM) Summer conventional milk; (WOM) Winter organic milk; (WPM) Winter pasture milk; (WCM) Winter conventional milk; (TFA) Trans fatty acid; (CLA); Conjugated linoleic acids; (SFA); Saturated fatty acid; (MUFA).Monounsaturated fatty acid (PUFA); Polyunsaturated fatty acid; ${ }^{\text {acc }}$ Means with different superscripts are significantly different $(\mathrm{P}<0.05)$ according to the Mann-Whitney U-test. 

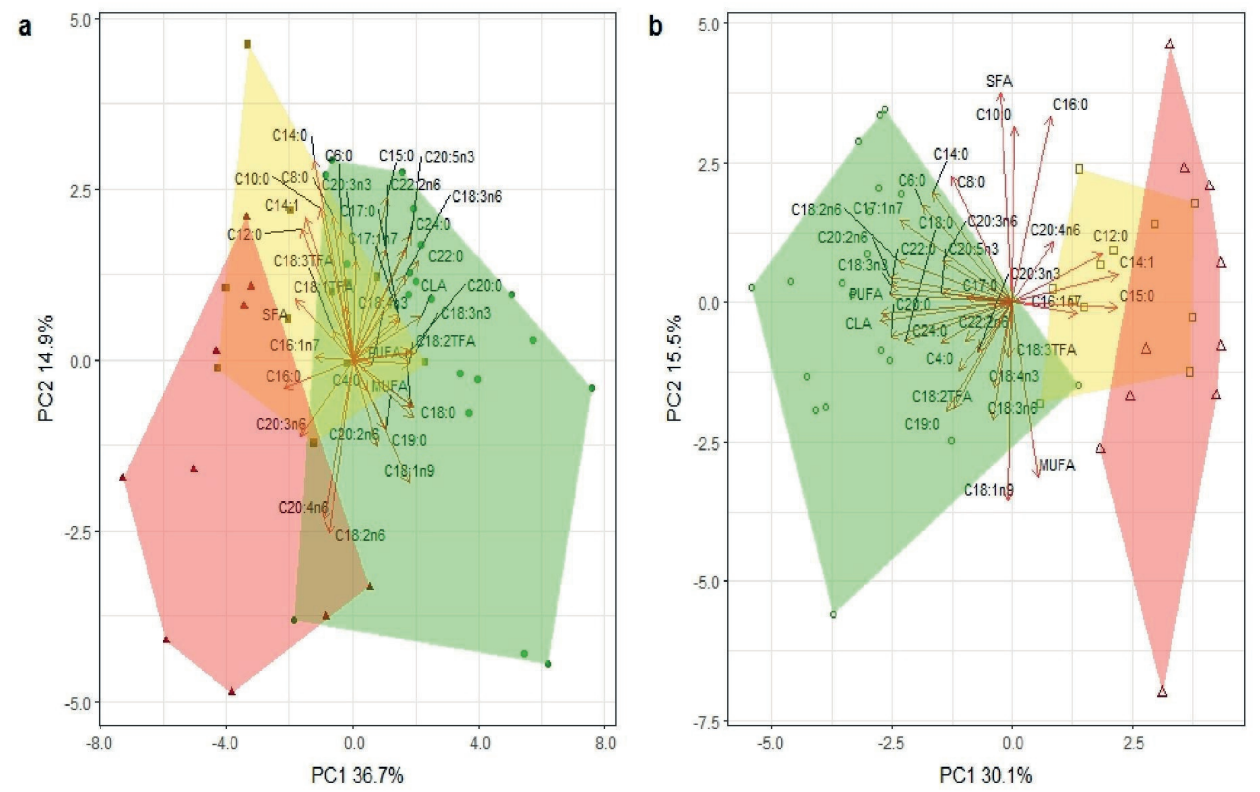

c

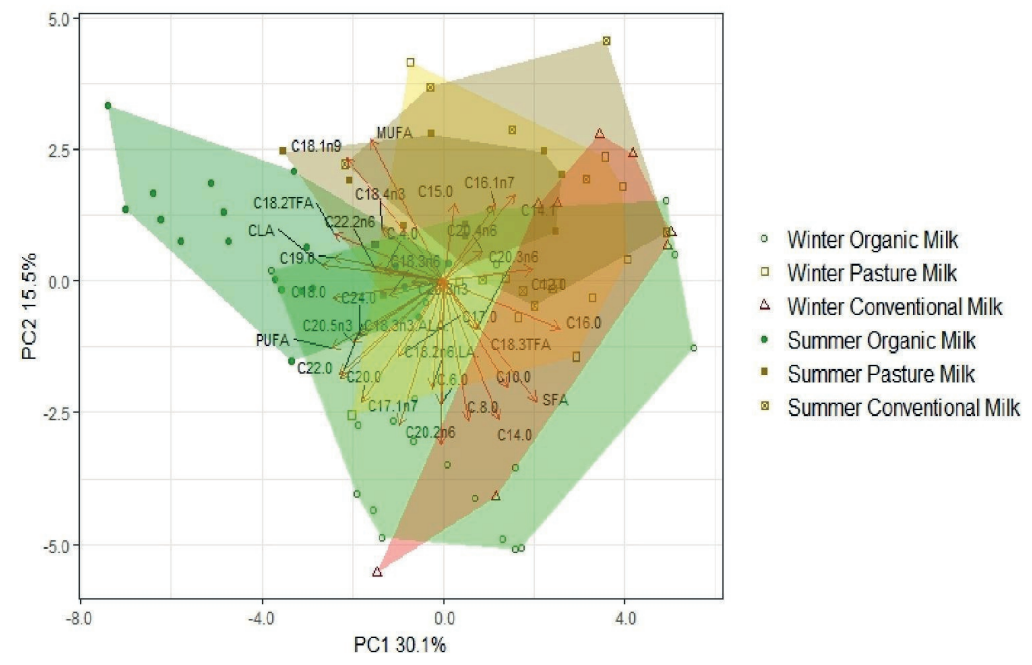

Fig. 2.2 Principal component analysis (PCA) scores and loadings plots of the first two principal components of the fatty acid compositions of different types of milk obtained from the European summer and winter periods: (a) summer milk PCA biplot; (b) winter milk PCA biplot; (c) PCA biplot of summer and winter milks.

\subsubsection{Correlation between the fatty acid profiles of forages and milk of the three} production systems

To link the FAs from forage to milk, the relationships between the FAs in the milk and the dominant FAs in forages, including six individual FAs (C16:0, C16:1n7, C18:0, C18:1n9, 
C18:2n6, and C18:3n3) and four FA groups (CLA, SFA, MUFA, and PUFA) were evaluated with Pearson correlation coefficients. Fig. 2.3 shows the significant $(\mathrm{P}<0.05)$ Pearson correlation coefficients between different types of forages and milk. It is interesting to note that in winter, $\mathrm{C} 18: \ln 9$ in organic milk (i.e. cows consuming winter organic silage) and pasture milk (i.e. cows consuming winter pasture silage) showed significant positive correlation with stearic acid (C18:0) in the forages (Fig. 2.3). The proportions of PUFA in milk were observed to have a significant positive correlation with concentration of PUFA and $\mathrm{C} 18: 1 \mathrm{n} 9$ in the winter organic $(\mathrm{r}=0.49 ; \mathrm{P}=0.03$ and $\mathrm{r}=0.51 ; \mathrm{P}=0.04$ respectively) and pasture forages $(\mathrm{r}=0.62 ; \mathrm{P}=0.04$ and $\mathrm{r}=0.63 ; \mathrm{P}=0.03$ respectively). According to the Pearson correlations (Fig. 2.3), the amount of CLA was linked to the proportions of $\mathrm{C} 18: 3 \mathrm{n} 3$ in summer organic forages, winter organic forages and winter pasture forages $(\mathrm{r}=0.51 ; \mathrm{P}=0.02, \mathrm{r}=0.55 ; \mathrm{P}=0.03$, and $\mathrm{r}=0.72 ; \mathrm{P}=0.01$, respectively).

\subsubsection{Classification model}

To explore the discriminant capability of GC analysis in classifying different milks, a classification model was developed based on a supervised pattern recognition algorithm, PLSDA. According to the results of cross validation, autoscale was selected as the pre-processing method and the number of the components was set as five. Under these circumstances, the overall accuracies of the training set and validation set were $87.5 \%$ and $83.5 \%$ respectively (Supplementary Table 2.1). In terms of the results of the prediction dataset, $15.4 \%$ of the organic milk samples (2/13) were classified as pasture milk and $7.2 \%$ of the organic milk samples (1/15) was classified as conventional milk; $16.7 \%$ of the conventional milk samples (1/6) was classified as pasture milk; all the pasture milk samples were correctly classified as pasture milk. The details of the confusion matrix of the prediction set were presented in (Supplementary Table 2.2).

\subsection{Discussion}

\subsubsection{Effect of production systems on forage FA profiles}

Compared with the silages from CFs, silages from OFs had lower concentrations of C18:1n9, C18:2n6, and MUFA, and higher concentrations of C18:3n3. It was due to the different percentages of maize silages in organic forages and conventional forages. Higher levels of maize silages tend to increase the percentages of C18:1n9 and C18:2n6, and decrease the percentages of C18:3n3 (Keady, Kilpatrick, Mayne, et al., 2008). Meanwhile, the use of maize silage could also lead to the differences in milk MUFA level, since they reflect the differences in $\mathrm{C} 18: 1 \mathrm{n} 9$, which is the most dominate MUFA in silage forages. 


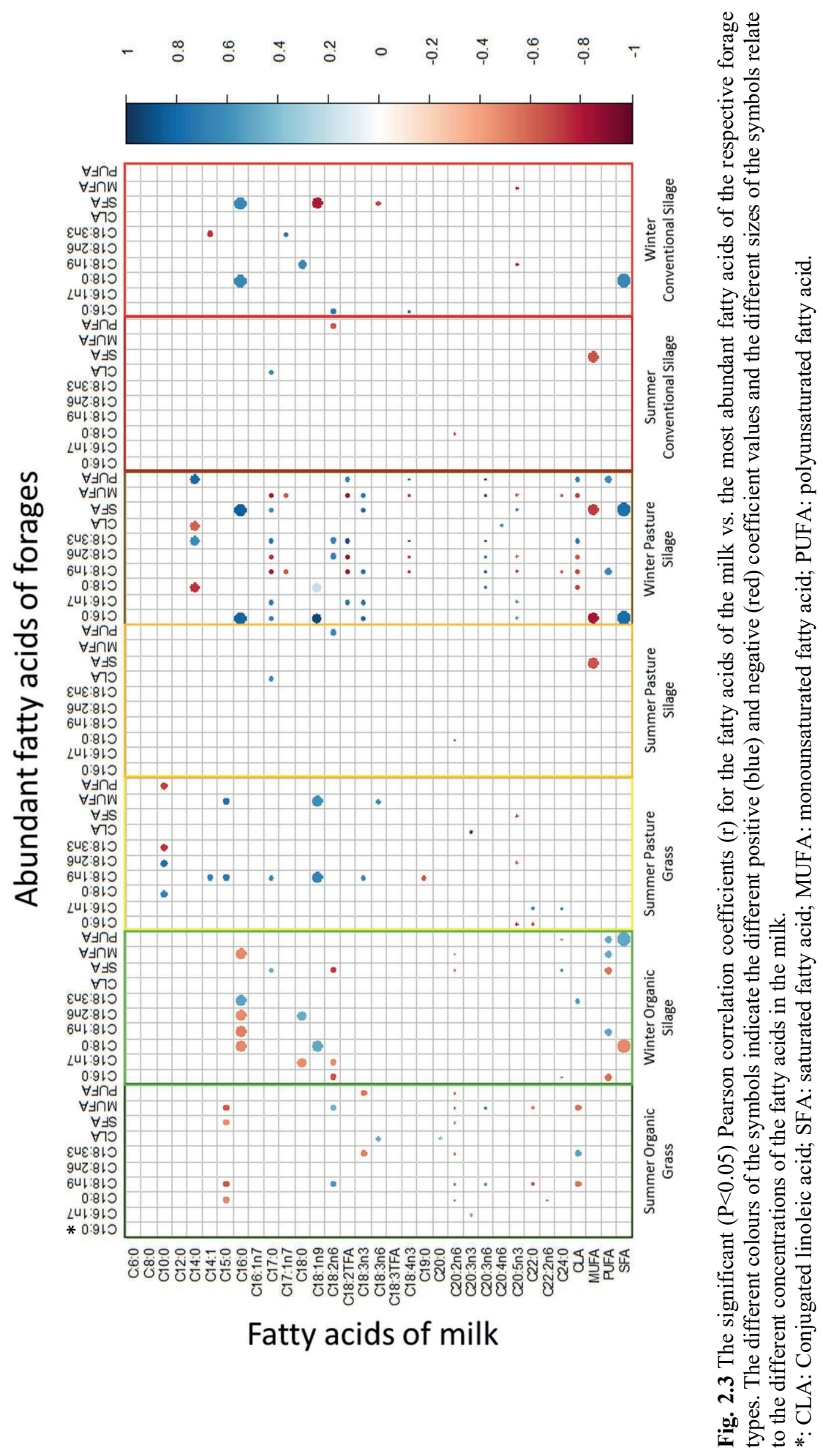


Another characteristic in Dutch organic dairy farms is the distinct botanical species growing in the fields (Table 2.1). Floral species vulnerable to herbicides and intensive management, such as Fabaceae, Brassicaceae and Polygonaceae, were previously shown to be more prominent in the fields of OFs. This kind of biodiversity is the result of banned usage of herbicides in organically cultivated fields (Hyvönen, Ketoja, Salonen, et al., 2003). Furthermore, organic farmers cultivate clover herbage for N2 fixation as an alternative method for nitrogen introduction (Elgersma \& Hassink, 1997), while CFs apply synthetic nitrogen fertilizers for that purpose. Clover herbage contains relatively more C16:0 and less C18:3n3, compared to grass herbage (Vanhatalo, Kuoppala, Toivonen, et al., 2007), similar to the findings of this study (Table 2.2), explaining the differences of $\mathrm{C} 16: 0$ and $\mathrm{C} 18: 3 \mathrm{n} 3$ between summer organic herbages and summer pasture herbages

The differences of $\mathrm{C} 18: 3 \mathrm{n} 3$ between summer organic herbages and summer pasture herbages could be explained by the utilizing of synthetic fertilizer as well. Since pasture farmers are allowed to apply synthetic fertilizers, it is easier for them to increase the nitrogen content in the field, which could significantly $(\mathrm{P}<0.01)$ increase the concentrations $\mathrm{C} 18: 3 \mathrm{n} 3$ in timothy grass (Boufaïed, Chouinard, Tremblay, et al., 2003).

In contrast to the previous study (Keady, et al., 2008), significant differences in C16:0 were not observed between different silages (Table 2.2). This could be due to the large diversity within pasture and conventional silages, which covered the variances of silages from different systems, and made the differences between groups less significant. Since the current study was carried out in natural uncontrolled conditions, the grass: maize silage ratio used per farm was inconsistent. Silages from different farms were made in different ways using different ratios of grass and maize. These factors could generate differences among different farms and forages (Mohd-Setapar, Abd-Talib, \& Aziz, 2012), and may thus be responsible for the large differences in feed FA compositions (Table 2.2).

From Fig. 2.1c, it also appears that, despite the effect of different harvesting seasons and cutting times, which are known to have a significantly impact on the quality of silage (Elgersma, et al., 2003; Kuoppala, Rinne, Nousiainen, et al., 2008), FA differences between conventional silage in winter and summer are negligible. The latter was also applicable to winter and summer pasture silage, showing negligible differences in FA concentrations in Table 2.2. One of the potential explanation was that dairy farmers mix the silages harvested in both harvesting season to make the ensiled forages quality more constant along the year. The forage analysis thus shows that production system and season, but especially the forage processing procedure, leads to differences in FA profiles.

\subsubsection{Effect of production systems on milk FA profiles}

The differences of C16:0 in summer organic, pasture, and conventional milks could be explained by the different amount of silages in the diets. Previous studies (Capuano, Grevink, 
Boerrigter-Eenling, et al., 2015; Capuano, et al., 2014; Coppa, Ferlay, Chassaing, et al., 2013) reported considerably more $\mathrm{C} 16: 0$ in milk derived from silage-fed cows. In summer time, only cows from OFs were fed with pure fresh herbage, without silage, while cows from PFs were fed with fresh herbage mixed with silage and conventional cows were only fed silage. In the same way, since all cows were fed with silage during winter, the concentrations of C16:0 did not show significant differences between different winter milk types. Similarly, high proportions of C18:1n9 in summer organic and pasture milk (Table 2.3) may be explained by cows grazing on fresh herbage, which is in accordance with the research carried out by Capuano et al. (2014).

Even though PF cows were partly grazing in the summer time, the differences of SFA and PUFA in pasture milk between winter and summer were small (Table 2.3). In the previous study mentioned, Capuano, et al. (2015) listed several potential factors that would obscure the unique characteristics of milk derived from grazing cows: grazing time in PFs may be insufficient; a mixture of milk from different farms may submerge some characteristics; fresh cut herbage is provided to indoor cows. However, in our study, milk samples from different farms were analysed separately and conventional cows were indoors throughout the year without fresh herbage intake. The most likely reason leading to the similar results is the unlimited supply of silage in PFs, even during summer time.

\subsubsection{Effect of production systems on forage-milk FA correlations}

According to the number of significant correlations (Fig. 2.3), long chain milk FAs (with more than 16 carbon atoms) possessed a comparable stronger relationship with these critical forage FAs. This result is likely related to the FA uptake and secretion pathways. FA uptake pertains to dietary long-chain FAs (Doreau, Meynadier, Fievez, et al., 2016), which are partly biohydrogenated and desaturated in the rumen and mammary gland, respectively (Elgersma, et al., 2004). In the mammary gland, short and medium chain FAs are de novo synthesised, while long chain FAs are absorbed from the blood and originate from both feed and fat deposits. Altogether, these processes cause a more direct relation between forage and milk composition for long chain FAs, compared to short and medium chain FAs. Stearic acid (C18:0), from feed or formed during biohydrogenation, can be absorbed in the digestive tract and transferred to the mammary gland, where it can be desaturated to oleic acid (C18:1n9), explaining the highlighted correlations between C18:0 and C18:1n9 in winter organic and PFs (Fig. 2.3). Meanwhile, Doreau, et al. (2016) reported a linear relationship between the amount of absorbable PUFA in the small intestine and the amount of PUFA intake from feedstuffs. Since the biohydrogenation specifically occurs in the rumen, after the absorption in the small intestine, the absorbed PUFAs could end up in the milk, illustrating the correlations between forage PUFA and milk PUFA in winter organic and PFs. Due to the perceived public health effect, another group of FAs, which draws consumers' attention, is CLA. As the most abundant FA in the diet, C18:3n3 is partly 
biohydrogenated in the rumen by the rumen bacterium, Butyrivibrio fibrisolvens. Increasing intakes of C18:3n3 by cows linearly increases milk CLA output (Elgersma, Ellen, Dekker, et al., 2003). Meanwhile, the activity of $\mathrm{B}$. fibrisolvens is highly dependent on rumen $\mathrm{pH}$ and the microbial biohydrogenation of $\mathrm{C} 18: 3 \mathrm{n} 3$ will be reduced if the rumen $\mathrm{pH}$ decreases (Pariza, Park, \& Cook, 2000), which may be a result of the consumption of maize and concentrate-based diets (Bessa, Santos-Silva, Ribeiro, et al., 2000; Doreau, et al., 2016). In the current study, significantly higher proportions of CLA in organic milk were observed both in summer and winter. However, the reasons leading to such significant abundance were different. During the summer period, the higher percentages of CLA was due to grazing, while during the winter period, it resulted from the silage composition on OFs, which contained no or less maize than conventional silage. Thus, the management and forages compositions and types are responsible for the distinct percentages of CLA in organic milk in summer and winter, respectively.

In terms of different production systems, the differences between forage-milk relationships in summer OFs and summer PFs could be mainly related to higher biodiversity levels in OFs. In the OFs, the percentages of grass in whole plant cover were lower than the percentages in the PFs (Table 2.1). Herbs contain higher levels of plant secondary compounds, such as polyphenol, than grass (Thorpe, Archer, \& DeLuca, 2006; Willems, et al., 2014). It has been shown previously that the level of total extractable phenols may have an impact on the process of lipolysis and biohydrogenation (Gerson, John, \& King, 1986). Higher levels of phenolic compounds were shown to reduce the biohydrogenation of C18:3n3 (Jayanegara, Kreuzer, Wina, et al., 2011). Besides phenols, fibre also showed different levels between grass, legume and herb (Willems, et al., 2014). A high level of fibre may inhibit the process of biohydrogenation and can thereby result in different relationships between forage FAs and milk FAs. Moreover, polyphenol oxidase released from some legume forages can increase lipid protection from endogenous lipolytic activity (Buccioni, et al., 2012). For example, adding red clover, which contains higher levels of polyphenol oxidase than grass, into diet, increased the transfer rate of $\mathrm{C} 18: 3 \mathrm{n} 3$ and $\mathrm{C} 18: 2 \mathrm{n}$ from forages to milk. A part of the major forage fatty acids, like $\mathrm{C} 18: 3 \mathrm{n} 3, \mathrm{C} 18: 2 \mathrm{n} 6$, and $\mathrm{C} 18: 1 \mathrm{n} 9$ could pass the rumen without being biohydrogenated. This can occur on pasture when cows graze grass and herbs in a young development stage, which then gives high forage intake and high passage rate of forage particles through the rumen. Moreover, Willems, et al. (2014) pointed out that the selective eating behaviour of grazing animals differs between farms with different levels of biodiversity. Ruminants tend to select plants to avoid negative impacts of single substances, which could theoretically affect the rumen passage rate (Villalba, et al., 2011). In addition to the different levels of biodiversity, the different relationships in OFs and PFs could be due to different FA levels in the organic forages and pasture forages as well. In our study, correlations between the proportions of milk PUFA and forage PUFA in winter PFs $(r=0.62)$ were stronger than the correlations in winter OFs $(r=0.49)$. On the contrary, PUFA portions in winter organic forages were higher than the 
portions of PUFA in winter pasture forages. According to the meta-analysis conducted by (Khiaosa-ard, Kreuzer, \& Leiber, 2015), the apparent recovery of PUFA is higher at low dietary PUFA levels, and decreases when the dietary PUFA levels increase.

\subsubsection{Classification model evaluation}

The pilot pattern recognition model was developed based on the concentrations FAs in different milks. The overall accuracy suggested that combined with chemometrics, different milks from different seasons could be correctly classified (20/24) according to their production systems. According to the results presented in the Supplementary Table 2.2, 2/3 of the misclassified organic milk samples were classified as pasture milk samples while the misclassified conventional sample was classified as pasture sample. Such kind of misclassifications matches with the previous conclusion (Capuano, et al, 2014) that pasture milk is a kind of intermediate milk between organic and conventional milk. In terms of the model contributions of different variables, the two FAs that had highest model projection scores were CLA (1.42) and C18:3n3 (1.31). The model projection score illustrates the role of each variable in terms of bulding classification models (Capuano, et al, 2014). Variables with higher scores stand for more contribution in classifying samples precisely. Hence, these three FAs played important roles in discriminat different milks, which are in accordance with findings in the previous sessions. Furthermore, since the model was developed and validated with milks from winter and summer, it proves that it is possible to discriminate different milks from different seasons with one model.

\subsection{Conclusions}

The current study investigated if there are significant differences between forages and milk from different production systems, as well as if there is any unique relationship between milk and the related forage per system, under uncontrolled conditions. It is important because those are the products that consumers buy in daily life. The study provided the differences between the FA profiles of related forages and a detailed assessment of the relations between milk and forage in three different dairy farming systems. During the winter period, the forages from CFs were poorer in C18:3n3 but richer in C18:2n6 and MUFA than the forages from OFs. During the summer period, the forages from PFs had higher concentrations of $\mathrm{C} 18: 3 n 3$ and lower concentrations of $\mathrm{C} 16: 0$ and $\mathrm{C} 18: 2 n 6$ than the forages from OFs. The variation of the conventional between seasons (summer and winter) was small as the diets were similar for both seasons, minimising the seasonal effect. For organic and pasture the seasonal effect was greater as there is a distinct change in feeding practices for summer and winter. The variation in FA concentration between systems was due to the different feeding practises and resulting diets of the animals. The study revealed that higher percentages of CLA in summer organic milk were due to grazing management in summer OFs, while higher percentages of CLA in winter organic milk were due to less maize in silage in winter organic forage. 
Overall, the results show that the organic cow's diet is different from those in other systems, which is particularly due to the grazing management in summer and silage composition in winter, and results in distinct features of the organic milk FA profile, which could be used to distinguish milks from different production systems.

\subsection{Funding}

This work was supported by the China Scholarship Council [grant number 201406350053, 2014].

\subsection{Acknowledgements}

The authors wish to acknowledge contributions made by Jan Wicher Krol of SKAL Biocontrole who assisted with farmer contacts in the initial phase of the sample collections. 


\subsection{References}

Adler, S. A., Jensen, S. K., Thuen, E., Gustavsson, A. M., Harstad, O. M., \& Steinshamn, H. (2013). Effect of silage botanical composition on ruminal biohydrogenation and transfer of fatty acids to milk in dairy cows. Journal of Dairy Science, 96(2), 1135-1147.

Altieri, M. A. (2018). Agroecology: the science of sustainable agriculture: CRC Press.

Benjamini, Y., \& Hochberg, Y. (1995). Controlling the false discovery rate: a practical and powerful approach to multiple testing. Journal of the royal statistical society. Series $B$ (Methodological), 289-300.

Bessa, R. J. B., Santos-Silva, J., Ribeiro, J., \& Portugal, A. V. (2000). Reticulo-rumen biohydrogenation and the enrichment of ruminant edible products with linoleic acid conjugated isomers. Livestock Production Science, 63(3), 201-211.

Boufaïed, H., Chouinard, P. Y., Tremblay, G. F., Petit, H. V., Michaud, R., \& Bélanger, G. (2003). Fatty acids in forages. I. Factors affecting concentrations. Canadian Journal of Animal Science, 83(3), 501-511.

Buccioni, A., Decandia, M., Minieri, S., Molle, G., \& Cabiddu, A. (2012). Lipid metabolism in the rumen: New insights on lipolysis and biohydrogenation with an emphasis on the role of endogenous plant factors. Animal Feed Science and Technology, 174(1), 1-25.

Butler, G., Nielsen, J. H., Slots, T., Seal, C., Eyre, M. D., Sanderson, R., \& Leifert, C. (2008). Fatty acid and fat-soluble antioxidant concentrations in milk from high- and low-input conventional and organic systems: seasonal variation. Journal of the Science of Food and Agriculture, 88(8), 1431-1441.

Capuano, E., Grevink, R., Boerrigter-Eenling, R., \& van Ruth, S. M. (2015). Fatty acid and triglycerides profiling of retail organic, conventional and pasture milk: Implications for health and authenticity. International Dairy Journal, 42, 58-63.

Capuano, E., van der Veer, G., Boerrigter-Eenling, R., Elgersma, A., Rademaker, J., Sterian, A., \& van Ruth, S. M. (2014). Verification of fresh grass feeding, pasture grazing and organic farming by cows farm milk fatty acid profile. Food Chemistry, 164, 234-241.

Chung, I.-M., Park, I., Yoon, J.-Y., Yang, Y.-S., \& Kim, S.-H. (2014). Determination of organic milk authenticity using carbon and nitrogen natural isotopes. Food Chemistry, 160, $214-$ 218.

Coppa, M., Farruggia, A., Ravaglia, P., Pomiès, D., Borreani, G., Le Morvan, A., \& Ferlay, A. (2015). Frequent moving of grazing dairy cows to new paddocks increases the variability of milk fatty acid composition. Animal, 9(4), 604-613.

Coppa, M., Ferlay, A., Chassaing, C., Agabriel, C., Glasser, F., Chilliard, Y., Borreani, G., Barcarolo, R., Baars, T., \& Kusche, D. (2013). Prediction of bulk milk fatty acid composition based on farming practices collected through on-farm surveys. Journal of Dairy Science, 96(7), 4197-4211. 
Doreau, M., Meynadier, A., Fievez, V., \& Ferlay, A. (2016). Ruminal metabolism of fatty acids: modulation of polyunsaturated, conjugated, and trans fatty acids in meat and milk A2 Watson, Ronald Ross. In F. D. Meester (Ed.). Handbook of Lipids in Human Function (pp. 521-542). US: AOCS Press.

Elgersma, A. (2015). Grazing increases the unsaturated fatty acid concentration of milk from grass-fed cows: A review of the contributing factors, challenges and future perspectives. European Journal of Lipid Science and Technology, 117(9), 1345-1369.

Elgersma, A., Ellen, G., Van der Horst, H., Boer, H., Dekker, P., \& Tamminga, S. (2004). Quick changes in milk fat composition from cows after transition from fresh grass to a silage diet. Animal Feed Science and Technology, 117(1-2), 13-27.

Elgersma, A., Ellen, G., Dekker, P., van der Horst, H., Boer, H., \& Tamminga, S. (2003). Effects of perennial ryegrass (Lolium perenne) cultivars with different linolenic acid contents on milk fatty acid composition. Aspects of Applied Biology, 70, 107-114.

Elgersma, A., Ellen, G., van der Horst, H., Muuse, B. G., Boer, H., \& Tamminga, S. (2003). Comparison of the fatty acid composition of fresh and ensiled perennial ryegrass (Lolium perenne L.), affected by cultivar and regrowth interval. Animal Feed Science and Technology, 108(1), 191-205.

Elgersma, A., \& Hassink, J. (1997). Effects of white clover (Trifolium repens L.) on plant and soil nitrogen and soil organic matter in mixtures with perennial ryegrass (Lolium perenne L.). Plant and Soil, 197(2), 177-186.

Ellis, K. A., Monteiro, A., Innocent, G. T., Grove-White, D., Cripps, P., Graham McLean, W., Howard, C. V., \& Mihm, M. (2007). Investigation of the vitamins A and E and $\beta$ carotene content in milk from UK organic and conventional dairy farms. Journal of Dairy Research, 74(04), 484-491.

Gerson, T., John, A., \& King, A. (1986). Effects of feeding ryegrass of varying maturity on the metabolism and composition of lipids in the rumen of sheep. The Journal of Agricultural Science, 106(3), 445-448.

Hyvönen, T., Ketoja, E., Salonen, J., Jalli, H., \& Tiainen, J. (2003). Weed species diversity and community composition in organic and conventional cropping of spring cereals. Agriculture, Ecosystems \& Environment, 97(1), 131-149.

Jayanegara, A., Kreuzer, M., Wina, E., \& Leiber, F. (2011). Significance of phenolic compounds in tropical forages for the ruminal bypass of polyunsaturated fatty acids and the appearance of biohydrogenation intermediates as examined in vitro. Animal Production Science, 51(12), 1127-1136.

Keady, T. W. J., Kilpatrick, D. J., Mayne, C. S., \& Gordon, F. J. (2008). Effects of replacing grass silage with maize silages, differing in maturity, on performance and potential concentrate sparing effect of dairy cows offered two feed value grass silages. Livestock Science, 119(1), 1-11. 
Khiaosa-ard, R., Kreuzer, M., \& Leiber, F. (2015). Apparent recovery of C18 polyunsaturated fatty acids from feed in cow milk: A meta-analysis of the importance of dietary fatty acids and feeding regimens in diets without fat supplementation. Journal of Dairy Science, 98(9), 6399-6414.

Leiber, F., Kreuzer, M., Nigg, D., Wettstein, H. R., \& Leo Scheeder, M. R. (2005). A study on the causes for the elevated $n-3$ fatty acids in cows' milk of alpine origin. Lipids, 40(2), 191-202.

Liu, N., Koot, A., Hettinga, K., de Jong, J., \& van Ruth, S. M. (2018). Portraying and tracing the impact of different production systems on the volatile organic compound composition of milk by PTR-(Quad)MS and PTR-(ToF)MS. Food Chemistry, 239, 201207.

Liu, N., Parra, H. A., Pustjens, A., Hettinga, K., Mongondry, P., \& van Ruth, S. M. (2018). Evaluation of portable near-infrared spectroscopy for organic milk authentication. Talanta, 184, 128-135.

Martin, B., Verdier-Metz, I., Buchin, S., Hurtaud, C., \& Coulon, J.-B. (2005). How do the nature of forages and pasture diversity influence the sensory quality of dairy livestock products? Animal Science, 81(2), 205-212.

Mogensen, L., Kristensen, T., Søegaard, K., Jensen, S. K., \& Sehested, J. (2012). Alfatocopherol and beta-carotene in roughages and milk in organic dairy herds. Livestock Science, 145(1-3), 44-54.

Mohd-Setapar, S., Abd-Talib, N., \& Aziz, R. (2012). Review on crucial parameters of silage quality. APCBEE Procedia, 3, 99-103.

Molkentin, J. (2013). Applicability of organic milk indicators to the authentication of processed products. Food Chemistry, 137(1-4), 25-30.

Pariza, M. W., Park, Y., \& Cook, M. E. (2000). Mechanisms of action of conjugated linoleic acid: evidence and speculation. Proceedings of the Society for Experimental Biology and Medicine, 223(1), 8-13.

Rey-Crespo, F., Miranda, M., \& López-Alonso, M. (2013). Essential trace and toxic element concentrations in organic and conventional milk in NW Spain. Food and Chemical Toxicology, 55(0), 513-518.

Revello-Chion, A., Tabacco, E., Peiretti, P. G., \& Borreani, G. (2011). Variation in the Fatty Acid Composition of Alpine Grassland during Spring and Summer. Agronomy Journal, 103(4), 1072-1080.

Schwendel, B. H., Wester, T. J., Morel, P. C. H., Fong, B., Tavendale, M. H., Deadman, C., Shadbolt, N. M., \& Otter, D. E. (2017). Pasture feeding conventional cows removes differences between organic and conventionally produced milk. Food Chemistry, 229, 805-813. 
Snedecor, G. W., \& Cochran, W. G. (1980). Statistical methods, 7th ed. Ames. USA: The Iowa State University Press.

Stergiadis, S., Leifert, C., Seal, C. J., Eyre, M. D., Nielsen, J. H., Larsen, M. K., Slots, T., Steinshamn, H. v., \& Butler, G. (2012). Effect of feeding intensity and milking system on nutritionally relevant milk components in dairy farming systems in the north east of England. Journal of Agricultural and Food Chemistry, 60(29), 7270-7281.

Thorpe, A. S., Archer, V., \& DeLuca, T. H. (2006). The invasive forb, Centaurea maculosa, increases phosphorus availability in Montana grasslands. Applied Soil Ecology, 32(1), $118-122$

Ueda, Y., Asakuma, S., Miyaji, M., \& Akiyama, F. (2015). Effect of time at pasture and herbage intake on profile of volatile organic compounds of dairy cow milk. Animal Science Journal, 87(1), 117-125.

Van Valenberg, H. J. F., Hettinga, K. A., Dijkstra, J., Bovenhuis, H., \& Feskens, E. J. M. (2013). Concentrations of n-3 and n-6 fatty acids in Dutch bovine milk fat and their contribution to human dietary intake. Journal of Dairy Science, 96(7), 4173-4181.

Vanhatalo, A., Kuoppala, K., Toivonen, V., \& Shingfield, K. J. (2007). Effects of forage species and stage of maturity on bovine milk fatty acid composition. European Journal of Lipid Science and Technology, 109(8), 856-867.

Vasta, V., D’Alessandro, A. G., Priolo, A., Petrotos, K., \& Martemucci, G. (2012). Volatile compound profile of ewe's milk and meat of their suckling lambs in relation to pasture vs. indoor feeding system. Small Ruminant Research, 105(1-3), 16-21.

Villalba, J., Provenza, F., K Clemensen, A., Larsen, R., \& Juhnke, J. (2011). Preference for diverse pastures by sheep in response to intraruminal administrations of tannins, saponins and alkaloids. Grass and Forage Science, 66(2), 224-236.

Villeneuve, M. P., Lebeuf, Y., Gervais, R., Tremblay, G. F., Vuillemard, J. C., Fortin, J., \& Chouinard, P. Y. (2013). Milk volatile organic compounds and fatty acid profile in cows fed timothy as hay, pasture, or silage. Journal of Dairy Science, 96(11), 7181-7194.

Willems, H., Kreuzer, M., \& Leiber, F. (2014). Alpha-linolenic and linoleic acid in meat and adipose tissue of grazing lambs differ among alpine pasture types with contrasting plant species and phenolic compound composition. Small Ruminant Research, 116(2-3), 153164. 


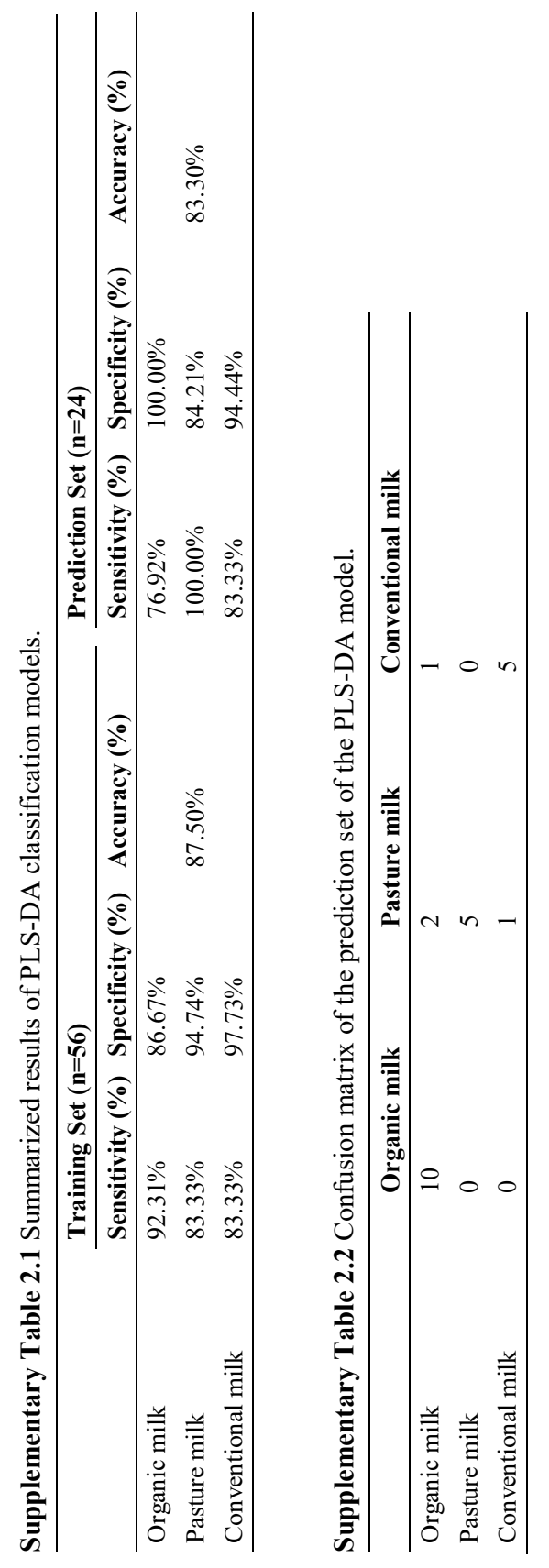




\section{Chapter 3 \\ Tracking volatile organic compounds from forage to milk for different production systems}

This chapter was submitted as: Ningjing Liu, Annemieke M. Pustjens, Kasper Hettinga, Saskia M. van Ruth, Tracking volatile organic compounds from forage to milk for different production systems. 


\begin{abstract}
This study aimed to investigate the underlying factors that lead to the unique volatile organic compound (VOC) profiles of milks from different production systems. Herbages, silages and milks were collected from 40 farms (19 organic, 11 pasture, and 10 conventional farms) in both winter and summer in the Netherlands. All samples were analysed for their VOC compositions by proton transfer reaction time of flight mass spectroscopy and the milks also for their fatty acid (FA) profiles by gas chromatography. Pearson correlation analyses were applied to study the relationship between VOCs of forages and milks, as well as between FAs and VOCs of milks. Seventy, twelve and seventy-eight masses that showed significant differences between different herbages, silages, and milks, respectively, were tentatively identified. The results revealed that the abundance of milk VOCs is strongly related to both the abundance of VOCs in herbages and the concentration of unsaturated FAs in milks.
\end{abstract}

Keywords: Correlation analysis; Forages; Milk; Organic; Volatile organic compound 


\subsection{Introduction}

As an important feature, the flavour of milk is not only an indicator of milk quality (Vallejo-Cordoba, \& Nakai, 1994), but also a key factor which directly affects consumer acceptability (Gandy, Schilling, Coggins, White, Yoon, \& Kamadia, 2008). The flavour of milk is generally determined by the volatile organic compounds (VOCs) in milk. These VOCs are, amongst others, related to the cows' metabolism, the interactions between cows and their environment, and microbiological activity in milk (Toso, Procida, \& Stefanon, 2002). Previous research showed that diet, breed, processing method and lactation stage (Gandy, Schilling, Coggins, White, Yoon, \& Kamadia, 2008; Yasuko, Sadaki, Makoto, \& Fumiaki, 2016) impacts the VOCs in milks. Furthermore, other compounds, especially fatty acids, can also have an impact on the VOCs in milks. Some VOCs in milks are short chain volatile fatty acids (FAs) or generated from breakdown of long chain FAs (Toso, Procida, \& Stefanon, 2002).

Next to that, the farming system of milk production also affects the VOC composition of milk. Our previous study has shown that organic retail milk presents a different VOC profile compared to other milks (Liu, Koot, Hettinga, de Jong, \& van Ruth, 2018). Such information can be used to design authentication tests and use VOCs as markers of milks from different production systems. However, since there are so many factors that can lead to different VOC profiles, the source of the differences in the VOC profiles of organic milk in comparison to other milks is not clear yet.

Dairy feedstuffs are mainly composed of concentrates and forages. Most dairy farmers in the Netherlands purchase concentrates from a few major feed companies, which makes concentrates fairly uniform on different farms. On the contrary, forages differ much more across farms, as these are mostly produced by the farmers themselves. Summer forages may consist of fresh herbage which varies among individual farms, especially in organic production where meadows may be diverse in composition. Moreover, the winter forage, mainly referring to silage, differs between farms too. Not only because of the different herbage raw material of which it is made may vary in composition, but also because of the addition of maize by some farmers to increase the nutritional value of the silage (O'mara, Fitzgerald, Murphy, \& Rath, 1998). Most current research focuses on the similarities and dissimilarities between different milks, but studies about the differences between organic forages and forages from other production systems are limited. A previous study reported the VOC profiles of South African lamb fat and herbaceous plants, and found links between the dominant VOCs of fat and plants (Erasmus, Muller, Alewijn, Koot, van Ruth, \& Hoffman, 2017). However, research on VOC profiles of both milk and related forages, and the direct link between them, has not been reported yet.

Traditional detection methods such as gas chromatography mass spectrometry (GC-MS) has been widely used to obtain VOC profiles of milk. Coppa, Martin, Pradel, Leotta, Priolo, 
and Vasta (2011) used solid-phase microextraction (SPME) to extract VOCs from milk fat, and analysed these extracted VOCs by GC-MS. The limitation of such analyses is that it is generally time-consuming. On the other hand, Capone, Epifani, Quaranta, Siciliano, Taurino, and Vasanelli (2001) used an electronic nose system (E-nose) to recognise the VOC patterns for monitoring the development of rancidity of milk. Compared with GC-MS, E-nose does not require complex sample preparation, but it can only provide a series of fingerprint signals measured in the headspace above the sample instead of information on the identity of the compounds. Therefore, to establish the link between milk and related forages, there is a need to explore other analytical techniques, which could provide a more detailed fingerprint with information on the identity of specific compounds.

A suitable candidate for such an analysis would be proton transfer reaction mass spectroscopy (PTR-MS), which allows rapid analysis of the full VOC profiles of samples without sample preparation. Combined with the orthogonal acceleration reflection time of flight (ToF), proton transfer reaction time of flight mass spectroscopy (PTR-(Tof)MS) can determine the exact mass values of the VOCs. This technique has been applied in several aspects of food analysis, such as cheese, meat, spices, etc. (Bergamaschi, Cecchinato, Biasioli, Gasperi, Martin, \& Bittante, 2016; van Ruth, Silvis, Alewijn, Liu, Jansen, \& Luning, 2019; Wojnowski, Majchrzak, Szweda, Dymerski, Gębicki, \& Namieśnik, 2018).

Considering the established consistent difference in VOC profiles between milks from different production systems, in this study we tried to elucidate the underlying causes. We studied the relationships between forage and milks in three systems: organic, pasture, and conventional milk production systems. Pasture milk production is a kind of intermediate green production system, which demands cows grazing for minimally six hours per day for 120 days a year. VOC profiles of forages, as well as the fatty acid (FA) composition and VOC profiles of milk were examined, considering that both forage and milk FAs are important sources of VOCs in milks. The VOC profiles were determined by PTR-(ToF)MS and the FA composition by gas chromatography (GC).

\subsection{Materials and methods}

\subsubsection{Samples}

Both during the European summer and winter period, forages and milks were collected from the same 40 dairy farms in the Netherlands (Supplementary Table 3.1). The major breed of cows in each farm is Holstein (>75\%). The summer sample set was obtained from July 2017 to August 2017 and the winter sample set was obtained from December 2016 to February 2017. During each period, the feed recipes and management strategy were constant throughout that period, which minimized the effect of different sampling dates. In summer, organic farms and conventional farms only used herbages and silages, respectively, and in winter all farms provided silage. However, pasture farms $(n=11)$ provided both herbages and silages in summer. 
Herbages from pasture farms and organic farms were cut directly from grasslands. Therefore, 91 forage samples (61 silage samples and 30 herbage samples) were collected all together. All samples were stored at $-18{ }^{\circ} \mathrm{C}$ until analysis.

\subsubsection{Analysis of volatile organic compounds (VOCs)}

Eighty forage samples and 80 milk samples were analysed by PTR-(ToF)MS (Ionicon $\mathrm{GmbH}$, Innsbruck, Austria) to measure the VOC profiles and to tentatively identify the chemical formula for each mass. The temperature of the inlet was $61{ }^{\circ} \mathrm{C}$ and the reaction chamber was operated at a $1000 \mathrm{~V}$ drift voltage, a $3.80 \mathrm{mbar}$ drift pressure, and an E/N of 135 $\mathrm{Td}\left(1 \mathrm{Td}=10^{-17} \mathrm{Vcm}^{2}\right)$. Scanning was operated for $1 \mathrm{~s}$, ranging from $\mathrm{m} / \mathrm{z} 17$ to 507 . In this research, milk $(5 \mathrm{ml})$ and forage $(0.5 \mathrm{~g})$ samples were placed into $250 \mathrm{ml}$ flasks with plastic screw caps (both Duran, Mainz, Germany). The samples were equilibrated in a $35{ }^{\circ} \mathrm{C}$ water bath for $30 \mathrm{~min}$ before the analysis of the headspace. Two independent replicates of each forage/milk sample were analysed. Each replicate was scanned 60 times, which resulted in an analysis time of $1 \mathrm{~min}$ per sample. Mass scale calibration and peak extraction were performed using PTRwid (Holzinger, 2015). The abundance of VOCs were shown in the format of counts per second. The results of duplicates were subsequently averaged.

\subsubsection{Data analysis}

According to the results of Shapiro test, the VOC concentrations were not normally distributed. Therefore, Kruskal-Wallis test was applied to determine if there were significant differences between different types of systems for forage VOCs, at a significance level of 5\%. Pairwise comparisons were carried out by Dunn's test to investigate different levels between groups. In a similar manner, the VOC compositions of the milk samples were also evaluated using the Kruskal-Wallis test and Dunn's test. To control the false discovery rate (FDR), P values were adjusted using Benjamini-Hochberg $(\mathrm{BH})$ adjustment. Principal component analysis (PCA) was used to visualise sample grouping and associations. To balance the weights of different variables, raw data were auto-scaled before PCA. The correlations between VOCs of milk and FAs of milks, and the correlations between VOCs and FA profiles of related samples were evaluated by Pearson's correlation coefficient (r). All the analyses were conducted using R 3.2.3 (R Foundation for Statistical Computing, Vienna, Austria).

\subsection{Results and discussion}

\subsubsection{VOC profiles of organic and other forages}

Forage samples were collected from 40 farms in both summer and winter. As an extreme example, the mean mass spectra of summer organic herbages and winter conventional silages are presented in Fig. 3.1a. Considering the large differences between herbages (summer organic herbage and summer pasture herbage) and silages (summer pasture silage, winter organic silage, 
winter pasture silage, and winter conventional silage), herbage and silage comparisons were carried out separately.
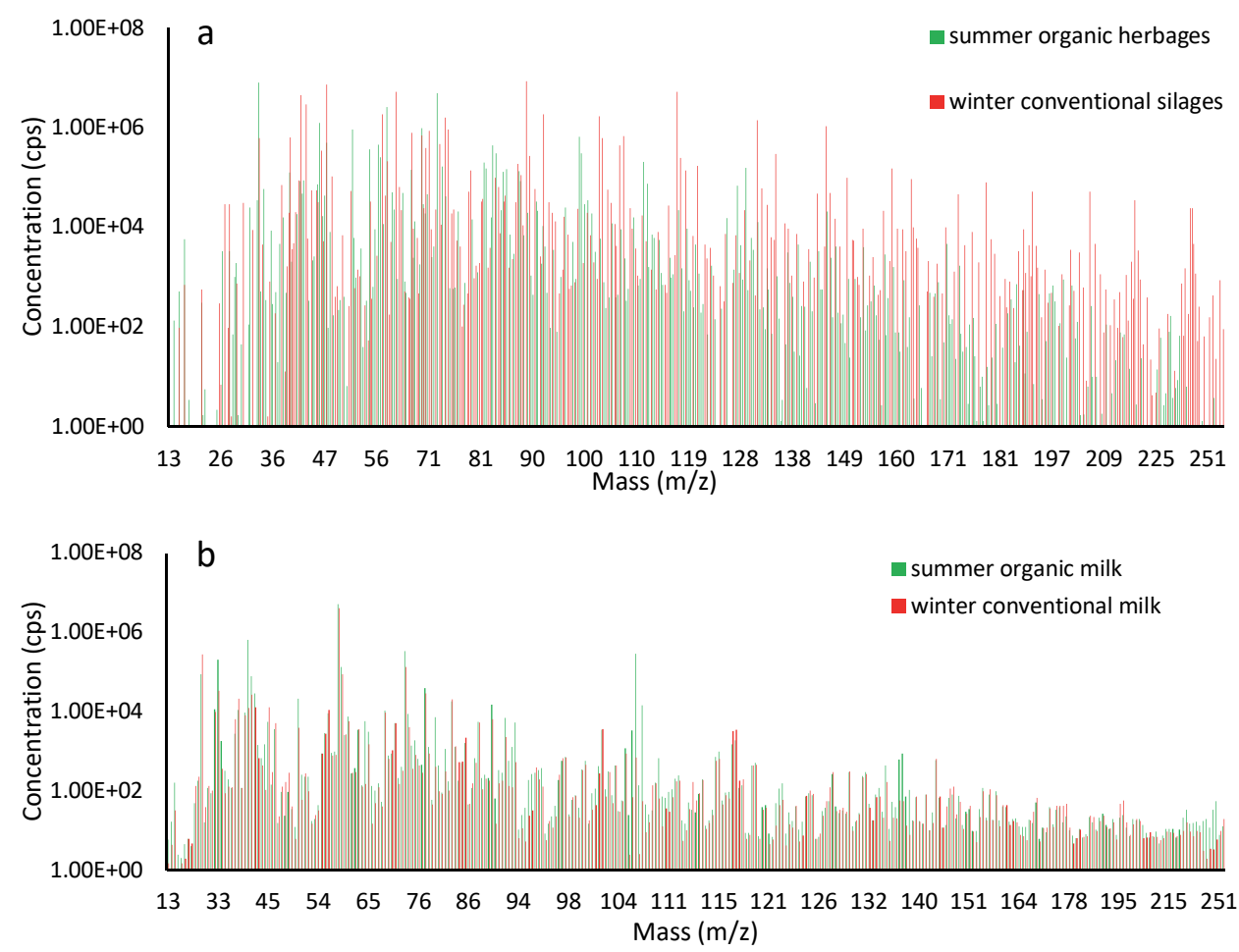

Fig. 3.1 PTR-(ToF)MS spectra of the volatile organic compounds of (a): summer organic herbages and winter conventional silages; (b): summer organic milk and winter conventional milk.

Fig. 3.2a shows the PCA score distributions of summer organic herbages and summer pasture herbages. There is a clear grouping trend of summer organic herbages versus summer pasture herbages. This can be explained by the different botanical species in the grassland of organic farms and pasture farms. Due to the usage of herbicides for weeds in pasture farms, the botanical variety is much poorer than the botanical variety in organic grassland (Battini, Agostini, Tabaglio, \& Amaducci, 2016; Hansen, Alrøe, \& Kristensen, 2001). The larger botanical variety of summer organic herbages also leads to spread over a larger area in Fig. 3.2a, which indicates that there is more variation between organic grasslands from different farms. Furthermore, another reason for the clear differences between summer organic herbages and summer pasture herbages is the cultivation of clover in organic farms. This is a common fertilisation alternative in organic production instead of the mineral $\mathrm{N}$ fertilizer applications in conventional production (Mäder, Fliessbach, Dubois, Gunst, Fried, \& Niggli, 2002). When comparing summer herbages, seventy masses with significantly different concentrations 
between organic and pasture were detected according to Kruskal-Wallis test. Thirty-one masses were tentatively identified and are listed in Table 3.1. Among all these tentatively identified masses, methanol ( $\mathrm{m} / \mathrm{z} 33.034)$, and butanone ( $\mathrm{m} / \mathrm{z}$ 73.064) were the most abundant masses and the concentrations of those were higher in organic herbages than in pasture herbages. Such results could be explained by the larger amount of clover in organic farms than pasture farms. Joost, Carleton, Thomas, and Fall (1999) concluded that compared with cut grass, cut clover emits up to 10 times more butanone and methanol during the same storage period. Kirsti, Galbally, Ye, and Hooper (1998) monitored the amount of VOCs released from grass meadow and clover meadow per hour per square meter, and their results suggest that the amounts of methanol and butanone emitted by clover slots are twice and ten times the amounts emitted by grass slots, respectively. Meanwhile, three oxygenated compounds, 2-methyl-2-propenal, pentanal, and hexanal show significant higher levels in summer pasture herbages compared to summer organic herbages. Since these three compounds are derived from fatty acids (FAs) in plants, especially from long chain polyunsaturated fatty acids (PUFA) (Pickett \& Khan, 2016), the different concentrations of them could be related to different FAs levels in summer organic herbages and summer pasture herbages. The result matched with the previous research, which suggested higher level of PUFA in summer pasture herbages (Liu, Pustjens, Yang, Erasmus, Hettinga, \& van Ruth, 2019).

Table 3.1 Abundances of volatile compounds showing significant differences between summer organic herbage (SOM) and summer pasture herbage (SPH): mean (log10) plus/minus standard deviations $(\log 10)$.

\begin{tabular}{|c|c|c|c|c|c|c|}
\hline $\begin{array}{l}\text { Mass } \\
(\mathrm{m} / \mathbf{z})\end{array}$ & $\begin{array}{l}\text { Protonated } \\
\text { chemical } \\
\text { formula }\end{array}$ & $\begin{array}{l}\text { Tentative } \\
\text { identification }\end{array}$ & $\begin{array}{l}\text { SOH } \\
\text { [cps] }\end{array}$ & $\begin{array}{l}\text { SPH } \\
\text { [cps] }\end{array}$ & Group & $\begin{array}{l}\text { Referen } \\
\text { ce }^{*}\end{array}$ \\
\hline 33.011 & & & $4.6 \pm 4.0$ & $4.4 \pm 3.7$ & & \\
\hline 33.034 & $\mathrm{CH}_{4} \mathrm{OH}^{+}$ & Methanol & $6.9 \pm 6.3$ & $6.7 \pm 6.1$ & alcohols & I, II, III \\
\hline 34.015 & & & $2.7 \pm 2.5$ & $2.9 \pm 2.6$ & & \\
\hline 34.037 & ${ }^{13} \mathrm{CH}_{4} \mathrm{OH}^{+}$ & Ethanol & $4.8 \pm 4.2$ & $4.6 \pm 4.0$ & alcohols & I, II, III \\
\hline 35.016 & & & $2.5 \pm 1.9$ & $2.4 \pm 1.6$ & & \\
\hline 35.038 & & & $3.9 \pm 3.3$ & $3.8 \pm 3.1$ & & \\
\hline 39.012 & & & $3.7 \pm 3.2$ & $3.4 \pm 3.0$ & & \\
\hline 40.026 & ${ }^{13} \mathrm{CC}_{2} \mathrm{H}_{2} \mathrm{H}^{+}$ & & $2.7 \pm 2.1$ & $2.5 \pm 1.9$ & alkenes & \\
\hline 41.038 & $\mathrm{C}_{3} \mathrm{H}_{4} \mathrm{H}^{+}$ & Isoprene fragment & $5.1 \pm 4.3$ & $5.0 \pm 4.5$ & alkenes & IV \\
\hline 43.017 & $\mathrm{C}_{2} \mathrm{H}_{2} \mathrm{OH}^{+}$ & Ester fragment & $5.0 \pm 4.7$ & $4.5 \pm 4.1$ & esters & $\mathrm{V}$ \\
\hline 43.037 & ${ }^{13} \mathrm{CCH}_{3} \mathrm{NH}^{+}$ & & $4.7 \pm 4.3$ & $4.3 \pm 3.7$ & & \\
\hline 43.053 & $\mathrm{C}_{3} \mathrm{H}_{6} \mathrm{H}^{+}$ & Propene & $5.0 \pm 4.7$ & $4.6 \pm 4.1$ & alkenes & VI \\
\hline 44.008 & $\mathrm{CHONH}^{+}$ & & $2.6 \pm 2.2$ & $2.2 \pm 1.6$ & & \\
\hline 44.022 & ${ }^{13} \mathrm{CCH}_{2} \mathrm{OH}^{+}$ & Ester fragment & $3.4 \pm 2.9$ & $3.0 \pm 2.4$ & ester & \\
\hline 44.055 & ${ }^{13} \mathrm{CC}_{2} \mathrm{H}_{6} \mathrm{H}^{+}$ & Propene & $3.4 \pm 3.0$ & $3.1 \pm 2.5$ & alkenes & VI \\
\hline 51.045 & & & $6.0 \pm 5.4$ & $5.8 \pm 5.2$ & & \\
\hline 52.046 & & & $3.8 \pm 3.2$ & $3.6 \pm 3.0$ & & \\
\hline
\end{tabular}




\begin{tabular}{|c|c|c|c|c|c|c|}
\hline $\begin{array}{l}\text { Mass } \\
(\mathrm{m} / \mathbf{z})\end{array}$ & $\begin{array}{l}\text { Protonated } \\
\text { chemical } \\
\text { formula }\end{array}$ & $\begin{array}{l}\text { Tentative } \\
\text { identification }\end{array}$ & $\begin{array}{l}\text { SOH } \\
{[\mathrm{cps}]}\end{array}$ & $\begin{array}{l}\text { SPH } \\
\text { [cps] }\end{array}$ & Group & $\begin{array}{l}\text { Referen } \\
\text { ce }^{*}\end{array}$ \\
\hline 53.001 & & & $2.6 \pm 2.0$ & $3.0 \pm 2.8$ & & \\
\hline 53.047 & & & $3.6 \pm 2.9$ & $3.3 \pm 2.5$ & & \\
\hline 54.044 & ${ }^{13} \mathrm{CC} 3 \mathrm{H}_{4} \mathrm{H}^{+}$ & & $2.5 \pm 1.7$ & $2.3 \pm 1.6$ & & \\
\hline 55.051 & $\mathrm{C}_{4} \mathrm{H}_{6} \mathrm{H}^{+}$ & Butadiene & $5.6 \pm 5.3$ & $5.2 \pm 4.7$ & alkenes & VI \\
\hline 56.022 & ${ }^{13} \mathrm{CC}_{2} \mathrm{H}_{2} \mathrm{OH}^{+}$ & & $2.8 \pm 2.2$ & $2.6 \pm 1.8$ & & \\
\hline 56.057 & ${ }^{13} \mathrm{CC}_{3} \mathrm{H}_{6} \mathrm{H}^{+}$ & Butadiene & $4.0 \pm 3.7$ & $3.5 \pm 3.1$ & alkenes & \\
\hline 57.035 & $\mathrm{C}_{3} \mathrm{H}_{4} \mathrm{OH}^{+}$ & Acrolein & $5.7 \pm 5.3$ & $5.5 \pm 5.2$ & aldehydes & VI \\
\hline 57.066 & $\mathrm{C}_{4} \mathrm{H}_{8} \mathrm{H}^{+}$ & 2-Butene & $5.4 \pm 4.9$ & $5.1 \pm 4.7$ & alkenes & VII \\
\hline 58.036 & ${ }^{13} \mathrm{CC}_{2} \mathrm{H}_{4} \mathrm{OH}^{+}$ & Acrolein & $4.1 \pm 3.6$ & $3.9 \pm 3.5$ & aldehydes & VI \\
\hline 59.050 & $\mathrm{C}_{3} \mathrm{H}_{6} \mathrm{OH}^{+}$ & Acetone & $6.6 \pm 6.5$ & $5.4 \pm 4.8$ & ketones & II \\
\hline 60.053 & ${ }^{13} \mathrm{CC}_{2} \mathrm{H}_{6} \mathrm{OH}^{+}$ & Acetone & $4.9 \pm 4.8$ & $3.8 \pm 2.9$ & ketones & II \\
\hline 61.027 & $\mathrm{C}_{2} \mathrm{H}_{4} \mathrm{O}_{2} \mathrm{H}^{+}$ & Acetic acid & $4.5 \pm 4.3$ & $4.0 \pm 3.9$ & acids & III \\
\hline 65.059 & $\mathrm{C}_{2} \mathrm{H}_{8} \mathrm{O}_{2} \mathrm{H}^{+}$ & Hydrated ethanol & $5.1 \pm 5.3$ & $5.4 \pm 5.4$ & alcohols & IV \\
\hline 66.062 & & & $3.5 \pm 3.4$ & $3.3 \pm 3.4$ & & \\
\hline 67.054 & $\mathrm{C}_{5} \mathrm{H}_{6} \mathrm{H}^{+}$ & Cyclopentadienyl & $4.1 \pm 3.3$ & $4.0 \pm 3.5$ & alkenes & VIII \\
\hline 68.067 & & & $3.3 \pm 2.3$ & $3.1 \pm 2.5$ & & \\
\hline 71.048 & $\mathrm{C}_{4} \mathrm{H}_{6} \mathrm{OH}^{+}$ & 2-Methyl-2-propenal & $4.1 \pm 3.9$ & $4.5 \pm 4.6$ & aldehydes & I \\
\hline 71.074 & & & $4.7 \pm 4.7$ & $4.5 \pm 3.9$ & & \\
\hline 72.055 & ${ }^{13} \mathrm{CC}_{3} \mathrm{H}_{6} \mathrm{OH}^{+}$ & 2-Methyl-2-propenal & $2.8 \pm 2.5$ & $3.5 \pm 3.2$ & aldehydes & I \\
\hline 72.075 & & & $3.7 \pm 3.3$ & $3.1 \pm 2.6$ & & \\
\hline 73.065 & $\mathrm{C}_{4} \mathrm{H}_{8} \mathrm{OH}^{+}$ & Butanone & $7.0 \pm 6.9$ & $5.1 \pm 4.8$ & ketones & II, IX \\
\hline 74.068 & ${ }^{13} \mathrm{CC}_{3} \mathrm{H}_{8} \mathrm{OH}^{+}$ & Butanone & $5.6 \pm 5.5$ & $3.6 \pm 3.1$ & ketones & \\
\hline 75.060 & $\mathrm{C}_{2} \mathrm{H}_{6} \mathrm{ON}_{2} \mathrm{H}^{+}$ & & $4.7 \pm 4.5$ & $4.1 \pm 3.7$ & & \\
\hline 76.045 & & & $2.8 \pm 2.4$ & $2.3 \pm 1.9$ & & \\
\hline 76.067 & & & $2.8 \pm 2.5$ & $2.2 \pm 1.9$ & & \\
\hline 76.088 & ${ }^{13} \mathrm{CC}_{2} \mathrm{H}_{6} \mathrm{O}_{2} \mathrm{H}^{+}$ & Methylacetate & $2.9 \pm 2.7$ & $2.1 \pm 1.9$ & esters & \\
\hline 77.074 & $\mathrm{C}_{2} \mathrm{H}_{8} \mathrm{ON}_{2} \mathrm{H}^{+}$ & & $4.0 \pm 3.8$ & $4.3 \pm 3.0$ & & \\
\hline 78.077 & ${ }^{13} \mathrm{CC}_{2} \mathrm{H}_{8} \mathrm{O}_{2} \mathrm{H}^{+}$ & & $2.9 \pm 2.3$ & $2.6 \pm 1.6$ & & \\
\hline 79.072 & & & $4.5 \pm 4.6$ & $3.9 \pm 3.9$ & & \\
\hline 83.085 & $\mathrm{C}_{6} \mathrm{H}_{10} \mathrm{H}^{+}$ & 1,4-Hexadiene & $5.7 \pm 5.4$ & $5.4 \pm 5.3$ & alkenes & VII \\
\hline 83.110 & & & $5.5 \pm 5.2$ & $5.3 \pm 5.1$ & & \\
\hline 84.087 & ${ }^{13} \mathrm{CC}_{5} \mathrm{H}_{10} \mathrm{H}^{+}$ & 1,4-Hexadiene & $4.4 \pm 4.0$ & $4.2 \pm 3.9$ & alkenes & \\
\hline 85.063 & $\mathrm{C}_{5} \mathrm{H}_{8} \mathrm{OH}^{+}$ & Pentenone & $5.1 \pm 4.8$ & $4.9 \pm 4.6$ & ketones & II \\
\hline 85.088 & $\mathrm{C}_{6} \mathrm{H}_{12} \mathrm{H}^{+}$ & 1-Hexene & $5.2 \pm 4.9$ & $4.8 \pm 4.5$ & alkenes & $\mathrm{X}$ \\
\hline 86.089 & & & $3.9 \pm 3.3$ & $3.7 \pm 3.2$ & & \\
\hline 86.118 & & & $3.5 \pm 3.2$ & $3.2 \pm 2.6$ & & \\
\hline 89.079 & $\mathrm{C}_{5} \mathrm{H}_{10} \mathrm{OH}^{+}$ & Pentanal & $3.9 \pm 4.0$ & $4.7 \pm 4.8$ & aldehydes & VIII \\
\hline 90.083 & ${ }^{13} \mathrm{CC}_{2} \mathrm{H}_{8} \mathrm{ON}_{2} \mathrm{H}^{+}$ & & $2.5 \pm 2.5$ & $3.2 \pm 3.2$ & & \\
\hline 90.113 & ${ }^{13} \mathrm{CC}_{3} \mathrm{H}_{12} \mathrm{~N}_{2} \mathrm{H}^{+}$ & & $2.0 \pm 1.9$ & $3.0 \pm 2.9$ & & \\
\hline 91.073 & $\mathrm{C}_{4} \mathrm{H}_{10} \mathrm{O}_{2} \mathrm{H}^{+}$ & & $4.8 \pm 4.6$ & $3.4 \pm 3.2$ & & \\
\hline 91.11 & $\mathrm{C}_{3} \mathrm{H}_{10} \mathrm{ON}_{2} \mathrm{H}^{+}$ & & $3.3 \pm 3.1$ & $4.5 \pm 4.4$ & & \\
\hline 92.077 & $\mathrm{C}_{3} \mathrm{H}_{9} \mathrm{O}_{2} \mathrm{NH}^{+}$ & & $2.4 \pm 2.0$ & $3.4 \pm 3.2$ & & \\
\hline 93.089 & & & $4.8 \pm 5.0$ & $3.9 \pm 4.2$ & & \\
\hline
\end{tabular}




\begin{tabular}{lllllll}
\hline $\begin{array}{l}\text { Mass } \\
(\mathbf{m} / \mathbf{z})\end{array}$ & $\begin{array}{l}\text { Protonated } \\
\text { chemical } \\
\text { formula }\end{array}$ & $\begin{array}{l}\text { Tentative } \\
\text { identification }\end{array}$ & $\begin{array}{l}\text { SOH } \\
\text { [cps] }\end{array}$ & $\begin{array}{l}\text { SPH } \\
\text { [cps] }\end{array}$ & Group & $\begin{array}{l}\text { Referen } \\
\text { ce }\end{array}$ \\
\hline 93.129 & & & $3.7 \pm 4.0$ & $4.5 \pm 4.7$ & & \\
94.091 & & $2.5 \pm 2.6$ & $3.1 \pm 3.2$ & & \\
94.116 & & $3.1 \pm 3.3$ & $2.5 \pm 2.7$ & & \\
95.080 & $\mathrm{C}_{7} \mathrm{H}_{10} \mathrm{H}^{+}$ & & $3.6 \pm 3.2$ & $3.5 \pm 2.8$ & & \\
96.082 & $\mathrm{C}_{6} \mathrm{H}_{9} \mathrm{NH}^{+}$ & & $3.1 \pm 2.8$ & $2.4 \pm 1.7$ & & \\
99.079 & $\mathrm{C}_{6} \mathrm{H}_{10} \mathrm{OH}^{+}$ & Cyclohexanone & $5.9 \pm 5.6$ & $5.7 \pm 5.5$ & ketones & VII \\
99.122 & $\mathrm{C}_{7} \mathrm{H}_{14} \mathrm{H}^{+}$ & 1-Heptene & $5.5 \pm 5.2$ & $5.3 \pm 5.1$ & alkenes & X \\
100.082 & ${ }^{13} \mathrm{CC}_{5} \mathrm{H}_{10} \mathrm{OH}^{+}$ & Cyclohexanone & $4.5 \pm 4.3$ & $4.3 \pm 4.1$ & ketones & \\
101.094 & $\mathrm{C}_{6} \mathrm{H}_{12} \mathrm{OH}^{+}$ & Hexanal & $4.3 \pm 4.0$ & $4.6 \pm 4.2$ & aldehydes & VI \\
101.138 & $\mathrm{C}_{7} \mathrm{H}_{16} \mathrm{H}^{+}$ & Heptane & $4.3 \pm 4.0$ & $3.9 \pm 3.7$ & alkanes & VII \\
\hline
\end{tabular}

*I: Kirsti, et al. (1998); II: Brilli, Hörtnagl, Bamberger, et al. (2012); III: Hafner, et al. (2013); IV:

Breitenlechner, Fischer, Hainer, et al. (2017); V: Liu, et al. (2018); VI: Koss, Sekimoto, Gilman, et al. (2018); VII: Malkina, Kumar, Green, et al. (2011); VIII: Daniel, et al. (2013); IX: Hafner, et al. (2013); X: Toso, et al. (2002).

Overall, summer organic herbages emit more VOCs then summer pasture herbages. Besides the botanical diversity, such differences could be explained by two other reasons. Firstly, since pesticides are not allowed in organic farms, plants tend to emit VOCs to prevent themselves from insects (Abrahamse, Dijkstra, Vlaeminck, \& Tamminga, 2008; Heil, 2008; Pickett, \& Khan, 2016). Secondly, the limited application of pesticides and wide use of organic fertilizer may have an impact on the abundance of fungi and bacteria, which could have contributed to the development of certain VOCs in the forage (Bennett, Hung, Lee, \& Padhi, 2012).

Fig. 3.2b shows the PCA score plots of summer pasture silages, summer conventional silages, winter organic silages, winter pasture silages, and winter conventional silages. Compared with Fig. 3.2a, there is no clear grouping of the samples of different origin. The results of the statistical tests to find differences between individual masses are shown in Table 3.2. Only twelve masses show significant differences between these four different silages. The potential explanation for the smaller number of significantly different masses could be a larger relative standard deviation within groups for silages than herbages, which could be due to two reasons. Firstly, different farms applied different silage recipes. In both conventional and pasture farms, the ratio of grass to maize in the silage of pasture farm and conventional farm ranged from 3:1 to 1:1. In the contrary, there is no maize involved in organic silages. Such large within-group variations can be larger than differences between different systems. Secondly, differences between silages would decrease due to fermentation. The stage of fermentation will then also become an important factor according to Hafner, Howard, Muck, Franco, Montes, Green, et al. (2013) who have proven that this affects VOC concentrations of silages. 

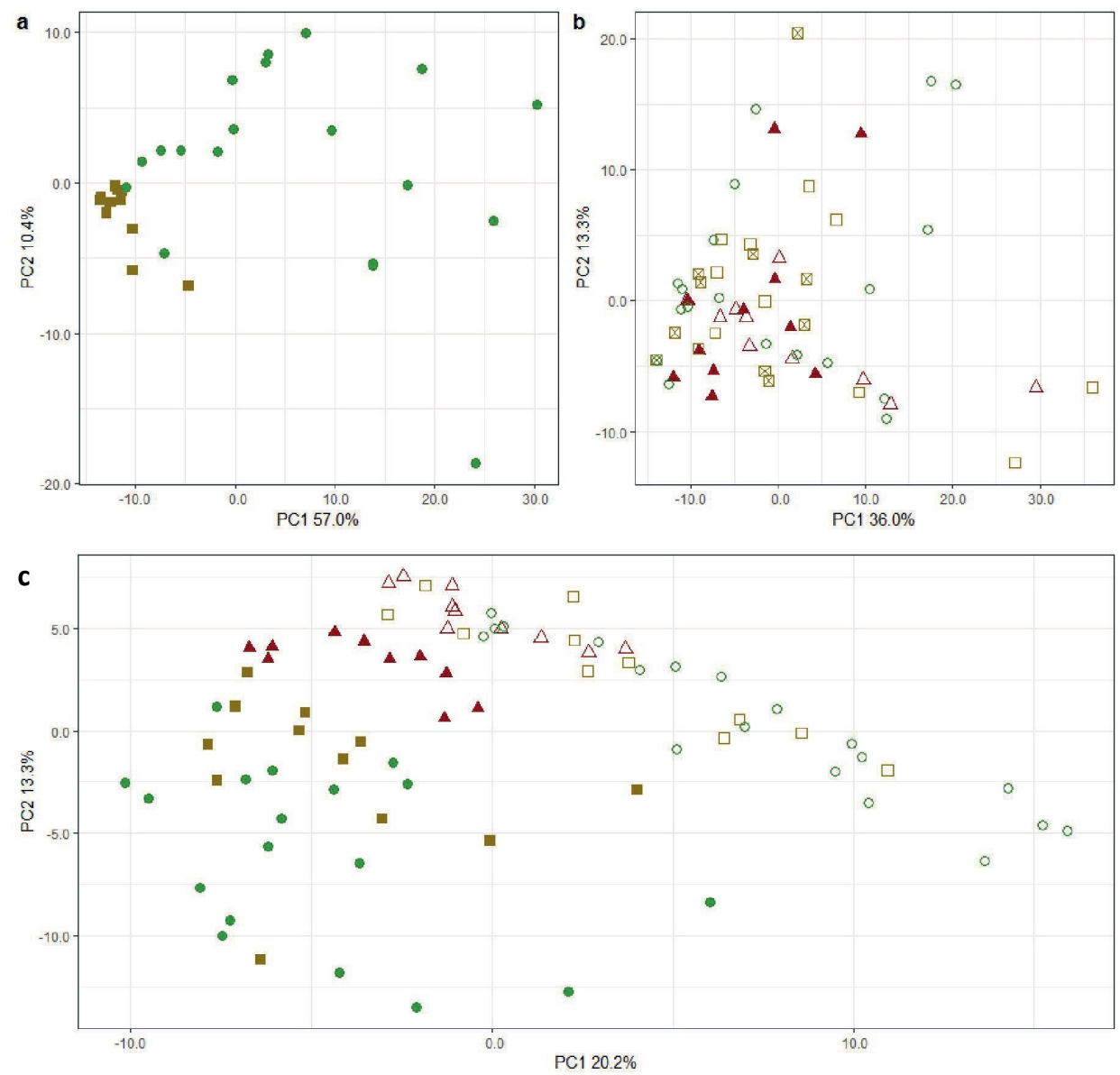

Fig. 3.2 Principal component analysis (PCA) score plots of the first two principal components of the volatile organic compound profiles of different forages and milks: (a) grass forages PCA score plot, summer organic herbages (green - ), summer pasture herbage (yellow $\mathbf{a}$ ); (b) silage forage PCA score plot, summer pasture silage (yellow $\boldsymbol{\otimes}$ ), summer conventional silage (red $\boldsymbol{\Delta}$ ), winter organic silage (green $\circ$ ), winter pasture silage (yellow $\square$ ), winter conventional silage (red $\triangle$ ); (c) milk PCA score plot, summer organic milk (green $\bullet$ ), summer pasture milk (yellow $\mathbf{\square}$ ), summer conventional milk (red $\Delta$ ), winter organic milk (green $\circ$ ), winter pasture milk (yellow $\square$ ), winter conventional milk (red $\triangle$ ).

\subsubsection{VOC profiles of organic and other milks}

To show the varieties of different milks, the mean mass spectra of summer organic milk and winter conventional milk, which are the two examples of the end of the scale, are presented in Fig. 3.1b. Unlike the comparison between herbages and silages, the trends of summer organic milk and winter conventional milk are more similar. To have a better view of the differences between different milks, the PCA score distributions of milks from different systems and seasons are presented in Fig. 3.2c. There is a clear separation of milks from summer (down left) 
and milks from winter (top right). The significant differences between VOC concentrations of summer and winter milks has been confirmed by other studies (Croissant, Washburn, Dean, \& Drake, 2007). The main reason leading to the gap between winter and summer milks is the difference in feeding strategies. In summer, organic and pasture cows grazed fresh herbages outdoors. However, in winter, all the cows were indoors and provided with silages. Furthermore, conventional milks from winter and summer are also distinguishable in Fig. 3.2c. Considering the consistent feeding strategy in conventional farms, these differences could be the results of difference in temperature between summer and winter. Sakatani, Balboula, Yamanaka, and Takahashi (2012) reported that the higher temperature in summer increases both body temperature and oxidative stress in Japanese Black cows. Bernabucci, Basiricò, Morera, Dipasquale, Vitali, Cappelli, et al. (2015) also confirmed the impact of higher temperature on milk protein fractions in Holstein cows. Furthermore, different enzymatic and microbial activities in summer (Fedele, Rubino, Claps, Sepe, \& Morone, 2005) would also change the VOC profiles of milks. Fig. 3.2c shows that summer pasture milks overlap with summer organic milk, while winter pasture milk is mixed with winter conventional milk. The same was observed in retail milk analyses (Liu, Koot, Hettinga, de Jong, \& van Ruth, 2018). The reason is that the feeding strategy applied in pasture farms is more similar to organic farms in summer and to conventional farms in wintertime.Table 3.3 shows the VOC concentrations of the various milks and their significant differences. Seventy-eight masses showed significant differences between different milks in both summer and winter.

Among the seventy-eight masses, acetone and butanone were most predominant. The concentrations of these two ketones, which are by-products of silage fermentation (Villeneuve, Lebeuf, Gervais, Tremblay, Vuillemard, Fortin, et al., 2013), were significantly higher in winter organic milk. That is because in winter, all cows from different farms are fed with silages. Croissant, Washburn, Dean, and Drake (2007) also observed that acetone and 2-butanone concentrations are higher in the milk derived from cows fed silages, intermediate in the milk derived from cows fed grass, and lower in the milk derived from cows fed hay. Furthermore, cows fed with grass silage could generate more 2-butanone in their milk than cows fed with maize silage (Toso, Procida, \& Stefanon, 2002). Similar results were reported by Tunick, Paul, Ingham, Karreman, and Van Hekken (2015), who found that the concentration of butanone in transitioning to organic (TTO) milk is 2-3 times higher than the concentration in conventional milk. In this research, the highest concentrations of acetone and butanone could be explained by the higher percentages of grass silage provided by organic farms in winter. Among all the masses which allowed the distinction of organic milk from other milks in summer, propene was the most abundant VOC. Propene is a compound released from fresh plants (Poisson, Kanakidou, \& Crutzen, 2000). The higher concentration of propene in summer organic milk relates to the higher proportion of fresh herbages consumed by the cows in organic farms in summer time. 


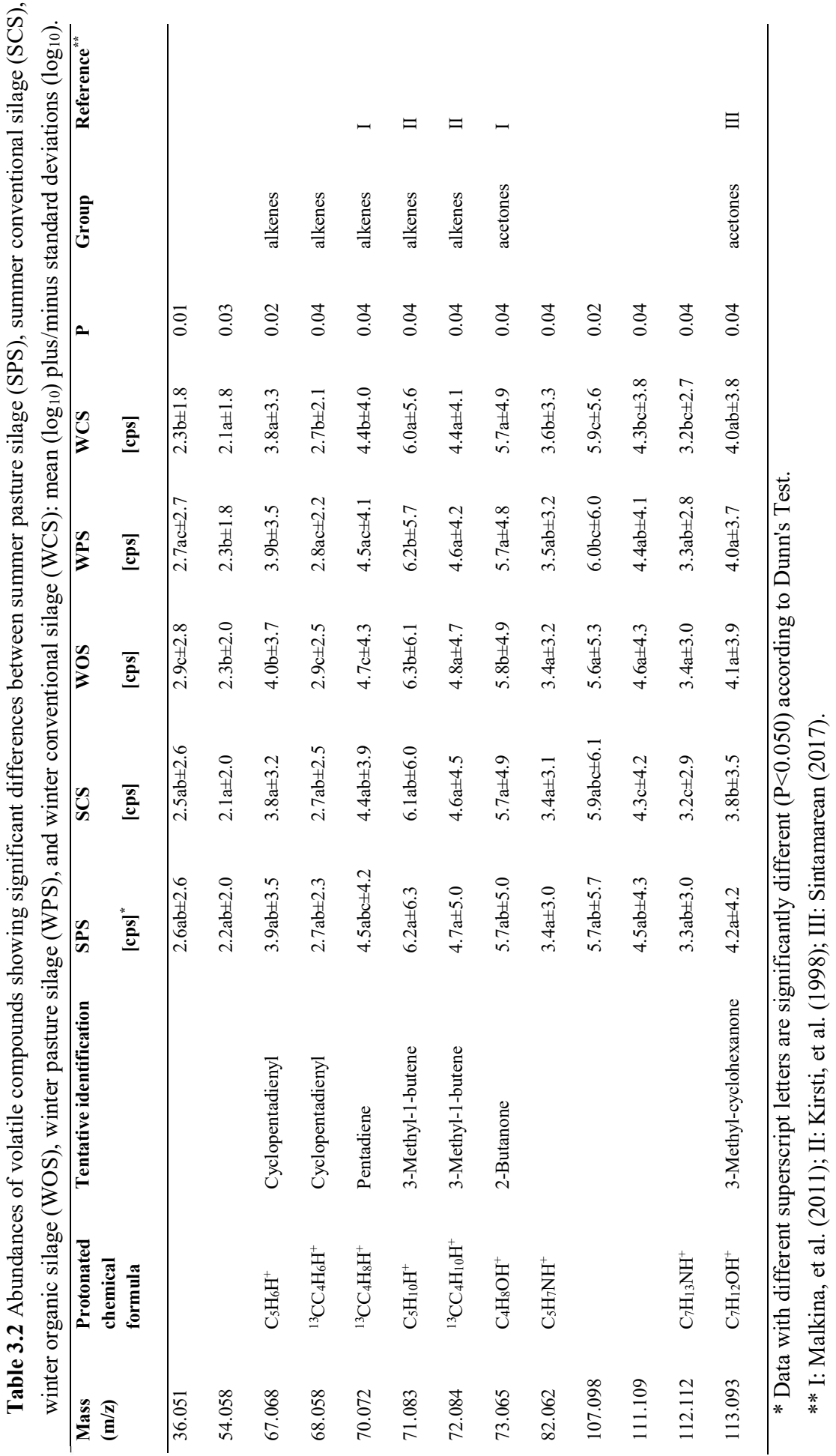




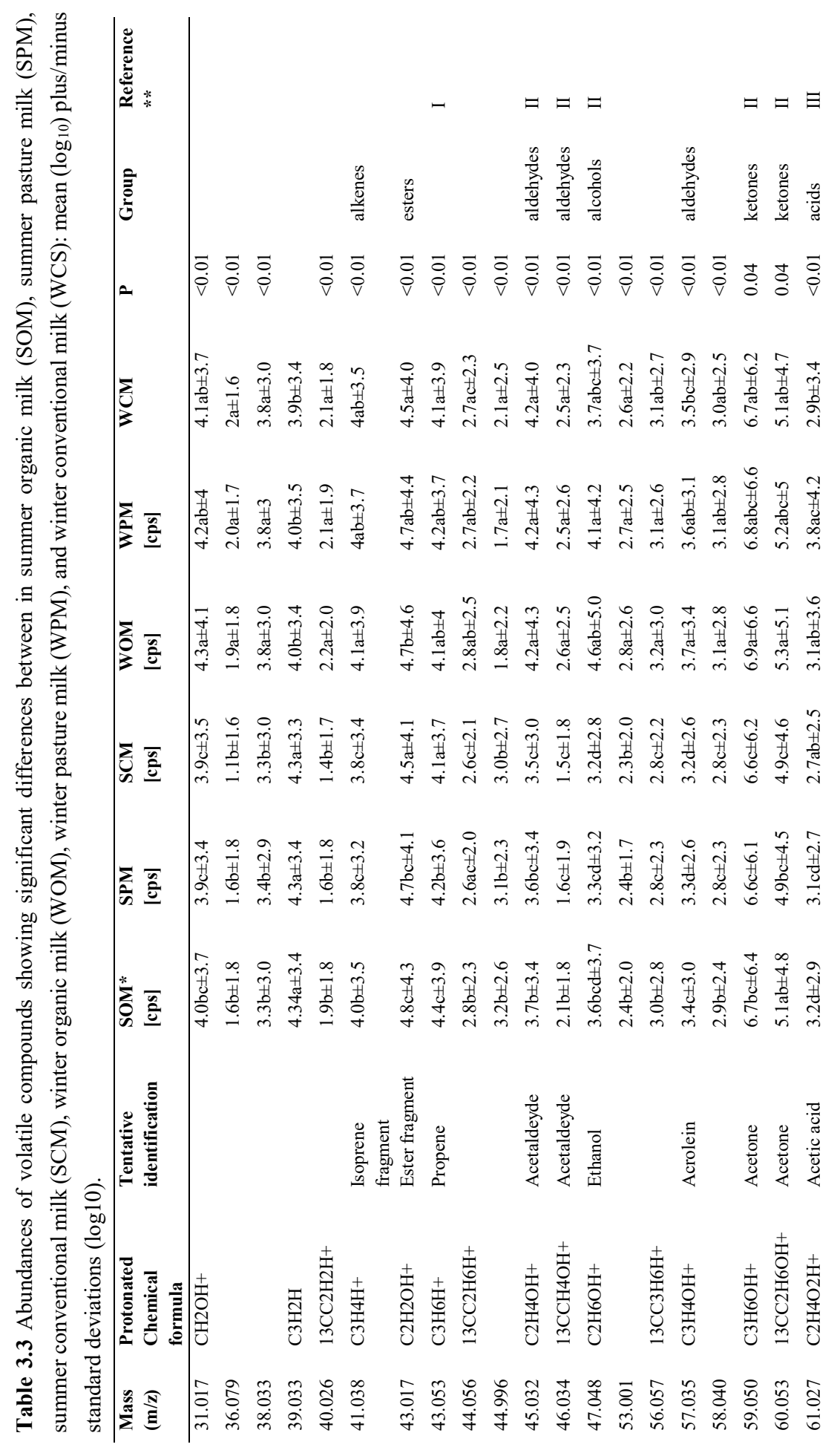




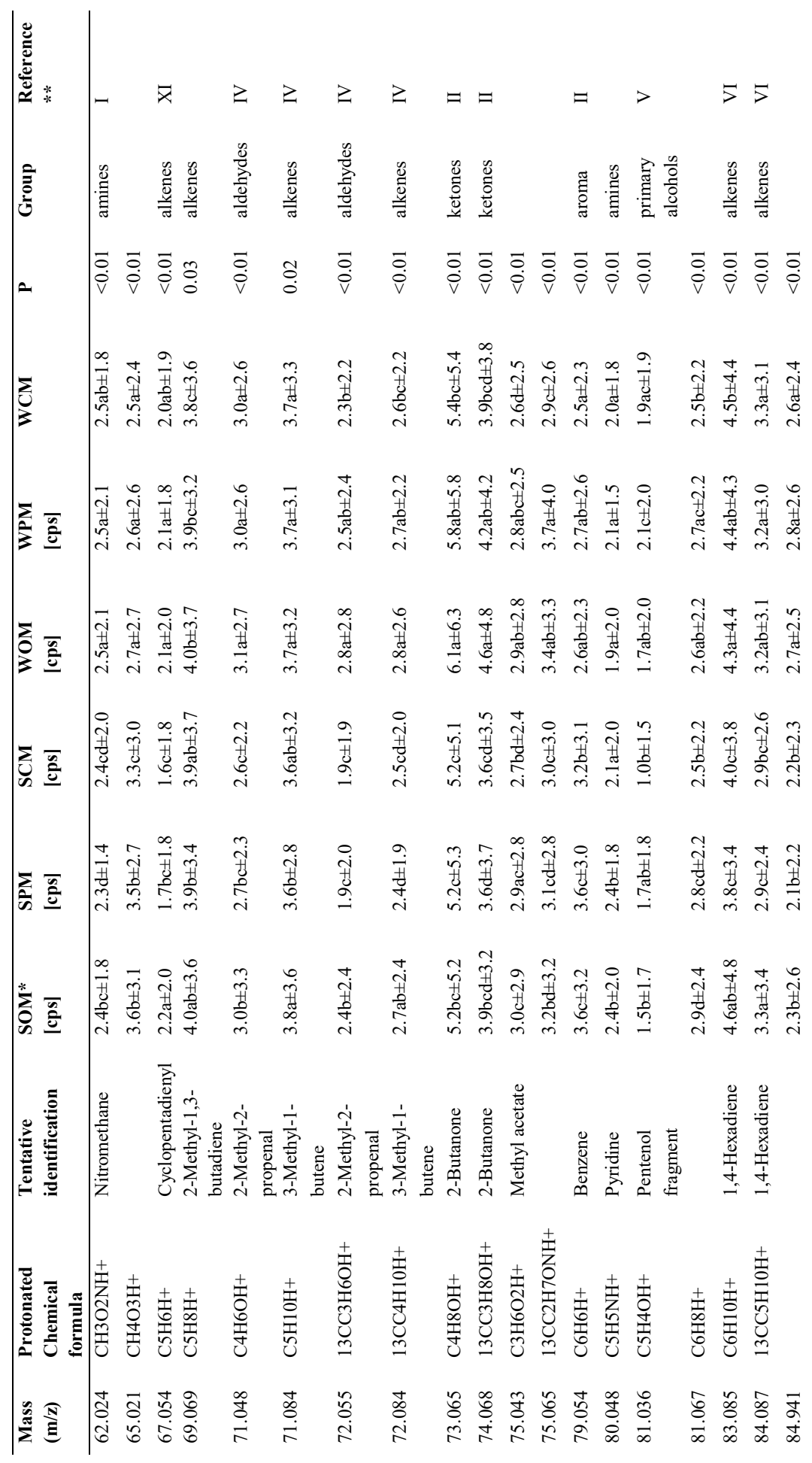




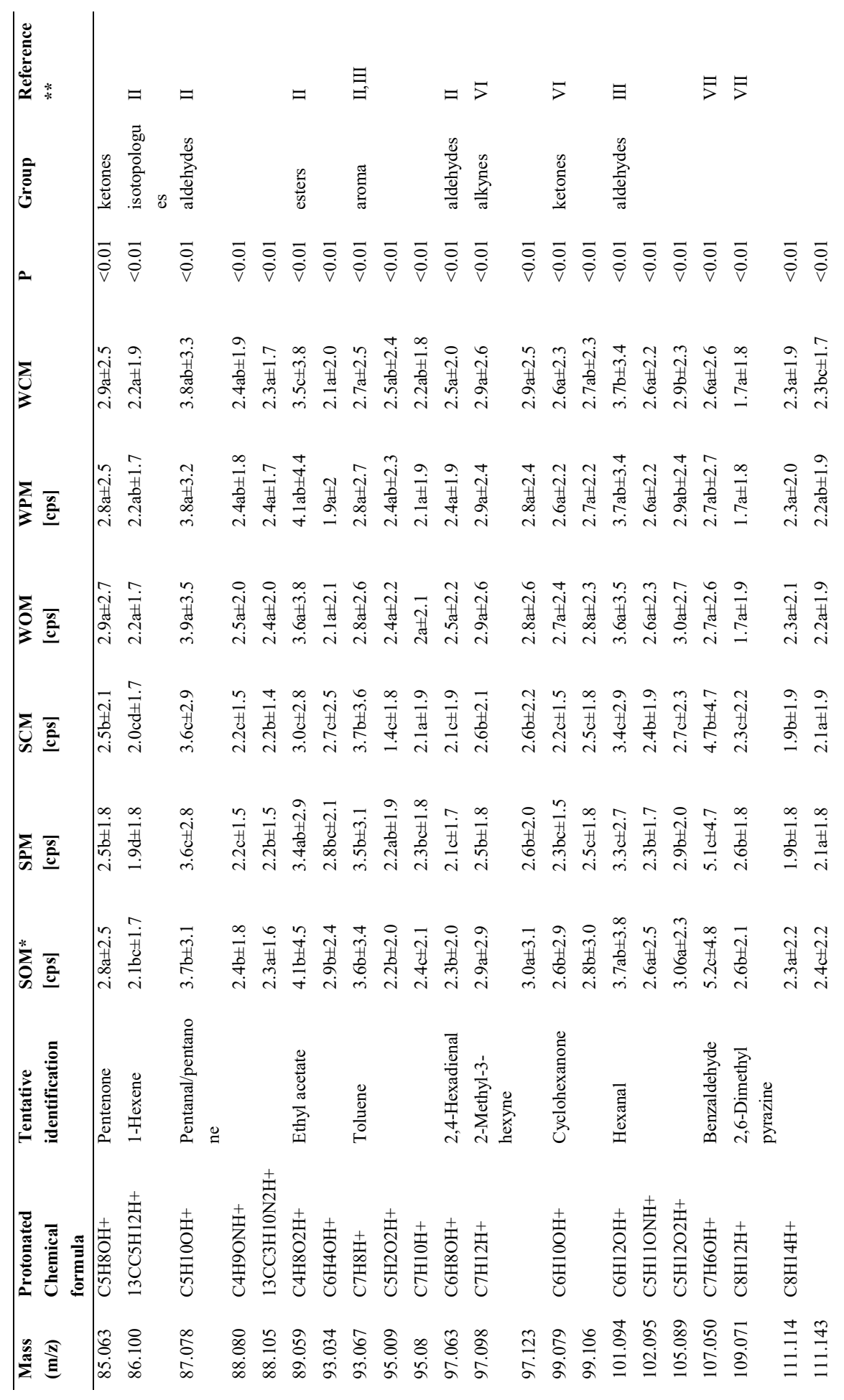




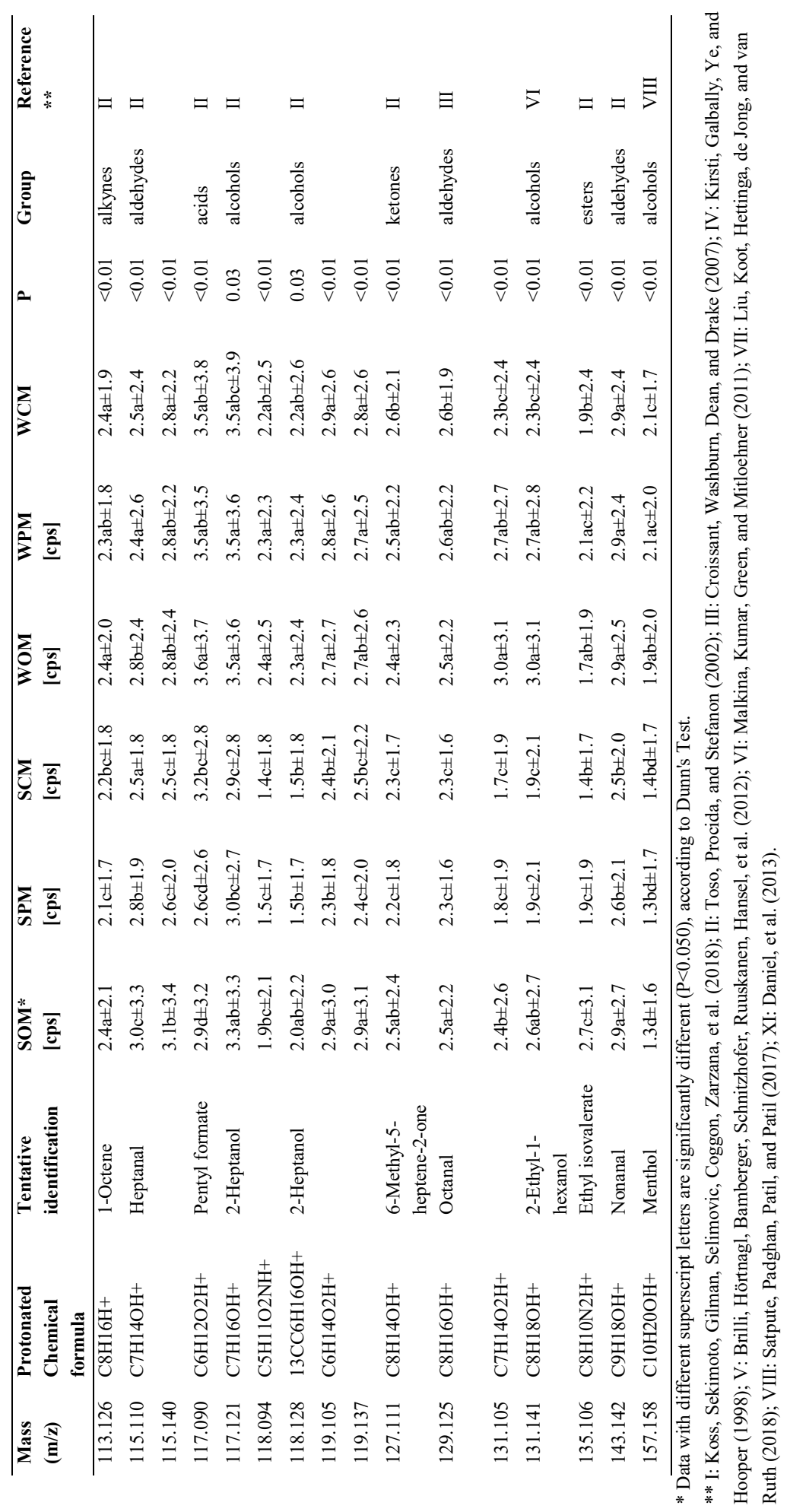




\subsubsection{The origins of characteristic VOCs in different milks}

To investigate the organics of characteristic VOCs in different milks, the correlations between VOCs of milk and FAs of milks, and the correlations between VOCs and FA profiles of related samples were evaluated. Phillips, Greenberg, and Awad (1994) described the potential sources of VOCs. A part of VOCs are inhaled or absorbed from food and environment. The others are synthesized or metabolised, including the oxidation and degradation of free FAs in different organs inside the body. Some of the generated and absorbed VOCs are metabolised to produce essential compounds, such as volatile fatty acids (Waldo \& Schultz, 1956) and provide energy (Daniel, Amaral, Goulart, Zopollatto, Santos, Toledo Filho, et al., 2013). The rest will be exhaled by breath, excreted via extrapulmonary pathways or distributed to body fluids and tissues by blood (Phillips, Greenberg, \& Awad, 1994). The part of VOCs delivered to the mammary gland (together with the VOCs generated in mammary gland) will finally appear in milk (Davis \& Collier, 1985).

In this research, tentatively identified masses listed in Table 3.3 were analysed by Pearson correlation with VOCs in related forages (3.3.1) and FAs in milks (3.3.2), aiming to investigate the origins of characteristic VOCs in different milks.

\subsubsection{Correlation between VOCs of forages and milks}

To study the transfer of significant VOCs from forages, Pearson correlation analysis were applied on the identified VOCs that demonstrated significant differences between production systems for both forages and milks. Propene, acrolein, acetone, acetic acid, cyclopentadienyl, 2-methyl-2-propenal, 2-butanone, 1,4-hexadiene, pentenone, cyclohexanone, and hexanal were selected to investigate the VOCs correlations between herbages and milks; cyclopentadienyl, 3-methyl-1-butene, and 2-butanone were selected to investigate the VOCs correlations between silages and milks.

Examining the organic system, it appears that propene $(\mathrm{r}=0.563 ; \mathrm{P}=0.012), 2$-butanone $(\mathrm{r}=0.670 ; \mathrm{P}=0.002$ and $\mathrm{r}=0.713 ; \mathrm{P}=0.001$ for isotopologues $), 1$, 4 -hexadiene $(\mathrm{r}=0.502 ; \mathrm{P}=0.028)$ and hexanal $(\mathrm{r}=0.569 ; \mathrm{P}=0.011)$ show significant correlations between summer organic herbages and summer organic milk. Previous studies (Mochalski, King, Klieber, Unterkofler, Hinterhuber, Baumann, et al., 2013; Fischer, Trefz, Bergmann, Steffens, Ziller, Miekisch, et al., 2015) proved that the concentrations of 2-butanone are significantly correlated with the concentrations in the air. Therefore, the explanation of the significant correlations between 2butanone in milk and herbages could be both the ingestion and inhalation during eating and walking on the grasslands. Once 2-butanone is present in blood, it is delivered to different tissues, including mammary gland, where it will be secreted with the milk. On the contrary, for the pasture system cyclohexanone $(\mathrm{r}=0.635 ; \mathrm{P}=0.036)$ shows a significant correlation between pasture herbages and pasture milks only. The presence of only one significant correlation is 
most likely due to the fact that pasture farms also provided silages in summer, of which the quantity and ratio differed from farm to farm.

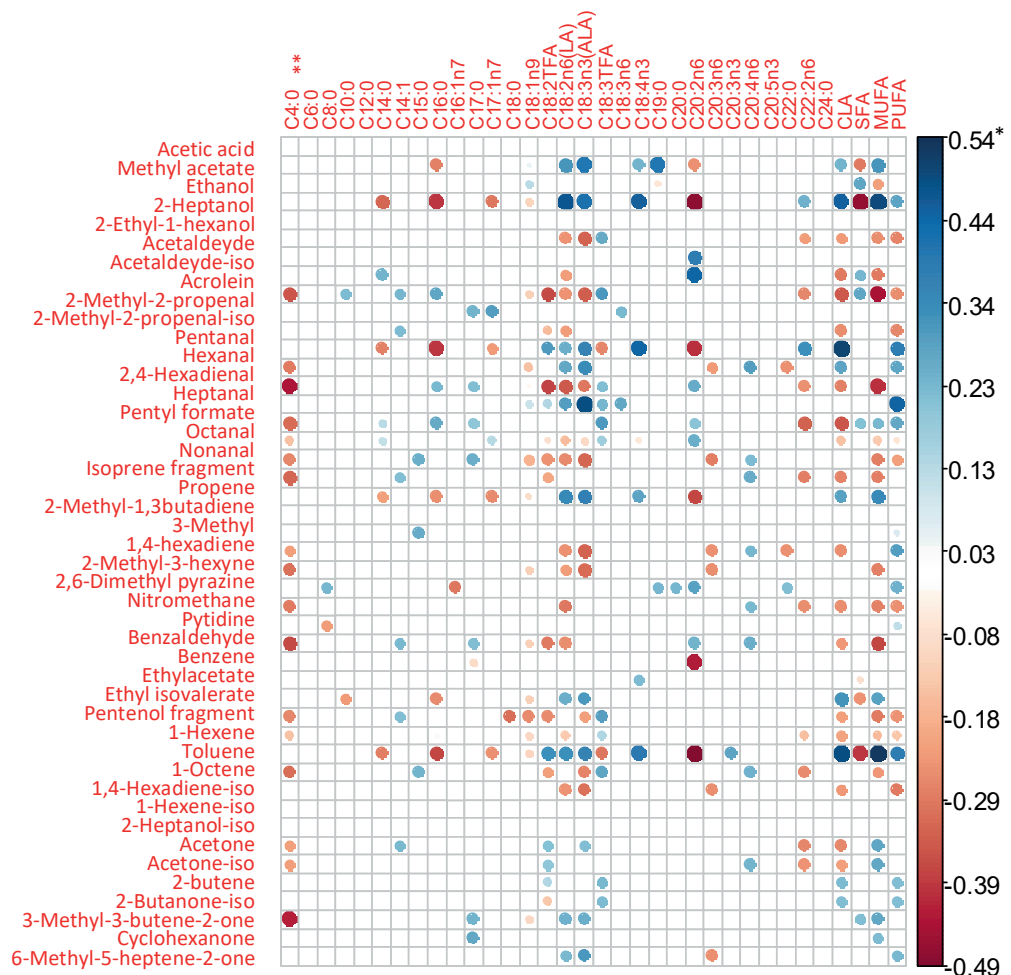

Fig. 3.3 Correlation coefficients for volatile compounds (VOCs) versus fatty acids (FAs) of milks.

*Significant correlations are shown in the pictures, different colours and sizes of the symbols stand for different coefficient values.

**LA: linoleic acid; TFA: total trans fatty acid; ALA: $\alpha$-linolenic acid; CLA: Conjugated linoleic acid; SFA: saturated fatty acid; MUFA: monounsaturated fatty acid; PUFA: polyunsaturated fatty acid.

For the relationship between VOCs of all silages and all milks (including pasture summer silage, conventional silage, and all the silages provided in winter), there is only one compound showing a significant correlation, i.e. 3 -methyl-1-butene $(r=0.677 ; \mathrm{P}=0.031)$. This significant correlation exists between summer conventional silage and milk, which suggests that the relationship of characteristic VOCs between silages and related milks was not strong. This phenomenon may be explained by the fact that fermentation end products of ensiling could be used by tissues and metabolized by rumen microorganisms as energy (Daniel, Amaral, Goulart, Zopollatto, Santos, Toledo Filho, et al., 2013). Furthermore, the lower number of characteristic VOCs of silages and the larger variation between silages (as discussed in 3.1) may also have led to the difficulties to uncover any correlations.

\subsubsection{Influence of FAs on VOC profiles of milks}


The correlations between milk FAs and VOCs were also examined. The FA composition of all the milk samples were obtained from a previously published part of this study (Liu, Pustjens, Erasmus, Yang, Hettinga, \& Van Ruth, 2020), which used the same set of samples but was focused on the FAs only. Fig. 3.3 shows the results of Pearson correlation analysis between FAs and VOCs of milks and significant correlations are highlighted.

According to reported research (Coppa, Martin, Pradel, Leotta, Priolo, \& Vasta, 2011; Elmore, Mottram, Enser, \& Wood, 2000; Vasta, D’Alessandro, Priolo, Petrotos, \& Martemucci, 2012; Young \& Baumeister, 1999) VOC profiles of ruminant products are related to the oxidation and degradation of free FAs. In this study, C18:2n6 (linoleic acid, LA), C18:3n3, conjunct linoleic acid (CLA), cumulated saturated fatty acids (SFA) and cumulated polyunsaturated fatty acids PUFA show strong correlations with the VOCs. This is because many VOCs including pentanal, hexanal, heptanal, octanal, and heptanol are the oxidation products of C18:3n3 and C18:2n6 (Elmore, Warren, Mottram, Scollan, Enser, Richardson, et al., 2004). Since C18:3n3 and C18:2n6 are the predominant PUFAs in milk (Liu, Pustjens, Erasmus, Yang, Hettinga, \& Van Ruth, 2020), it is not surprising that the cumulated PUFA values were also significantly correlated with those VOCs.

In the current study, $\mathrm{C} 18: 2 n 6$ and $\mathrm{C} 18: 3 n 3$ both show significant positive correlations with some aldehydes, such as pentanal and heptanal. Particularly the correlation coefficient between $\mathrm{C} 18: 3 \mathrm{n} 3 \quad(\mathrm{r}=0.49 ; \mathrm{P}=0.0046)$ and heptanal was among the highest correlation coefficients. Such results matched with previous findings reported by J. Elmore, Mottram, Enser, and Wood (2000), who showed that heptanal is derived from the autoxidation of $\mathrm{C} 18: 3 n 3$. A part of $\mathrm{C} 18: 3 n 3$ is broken down and generates (E,Z)-2,6-nonadienal that further degrades into heptanal. Since the concentration of $\mathrm{C} 18: 3 n 3$ is one of the indicators of grazing, heptanal could also serve as a marker for grazing. Vasta, D'Alessandro, Priolo, Petrotos, and Martemucci (2012) also illustrated a positive relationship between the amount of fresh grass in the cows' diets and heptanal in their milks and a negative relationship between the amount of concentrates in the diets of cows and heptanal in milk.

SFA shows significant negative correlations with some VOCs (in Fig. 3.3). The main reason that could explain these results is the negative correlation between SFAs and UFAs. The larger the fraction of SFA, the lower the intake of UFAs in the diet, and/or the more UFAs have been biohydrogenated in the rumen of the cow. Since many VOCs are derived from the oxidation of long chain UFAs, a smaller fraction of UFAs consequently leads to a lower amount of VOCs.

\subsection{Conclusions}

In this study, the VOC profiles of forages (including herbages in summer and silages in winter) and milks from different systems (organic, pasture, and conventional) were investigated. More significant differences were observed between different herbages, while less 
significant differences were found between different silages. On top of that, the Pearson correlations revealed that herbage VOCs present a stronger relationship with milk VOCs than silage VOCs. Furthermore, positive relationships were also found between unsaturated fatty acids and milk VOCs. The current results give a better understanding of the source of the milk VOCs which allow a distinction between organic milk from milks produced in other systems.

\subsection{Funding}

The first author received financially support for his $\mathrm{PhD}$ project by the China Scholarship Council. 


\subsection{References}

Abrahamse, P. A., Dijkstra, J., Vlaeminck, B., \& Tamminga, S. (2008). Frequent Allocation of Rotationally Grazed Dairy Cows Changes Grazing Behavior and Improves Productivity. Journal of Dairy Science, 91(5), 2033-2045.

Battini, F., Agostini, A., Tabaglio, V., \& Amaducci, S. (2016). Environmental impacts of different dairy farming systems in the Po Valley. Journal of Cleaner Production, 112, 91-102.

Bennett, J., Hung, R., Lee, S., \& Padhi, S. (2012). 18 Fungal and bacterial volatile organic compounds: an overview and their role as ecological signaling agents. In Fungal associations, (pp. 373-393): Springer.

Bergamaschi, M., Cecchinato, A., Biasioli, F., Gasperi, F., Martin, B., \& Bittante, G. (2016). From cow to cheese: genetic parameters of the flavour fingerprint of cheese investigated by direct-injection mass spectrometry (PTR-ToF-MS). Genetics Selection Evolution, $48(1), 89$.

Bernabucci, U., Basiricò, L., Morera, P., Dipasquale, D., Vitali, A., Cappelli, F. P., \& Calamari, L. (2015). Effect of summer season on milk protein fractions in Holstein cows. Journal of Dairy Science, 98(3), 1815-1827.

Brilli, F., Hörtnagl, L., Bamberger, I., Schnitzhofer, R., Ruuskanen, T. M., Hansel, A., Loreto, F., \& Wohlfahrt, G. (2012). Qualitative and Quantitative Characterization of Volatile Organic Compound Emissions from Cut Grass. Environmental science \& technology, 46(7), 3859-3865.

Capone, S., Epifani, M., Quaranta, F., Siciliano, P., Taurino, A., \& Vasanelli, L. (2001). Monitoring of rancidity of milk by means of an electronic nose and a dynamic PCA analysis. Sensors and Actuators B: Chemical, 78(1-3), 174-179.

Coppa, M., Martin, B., Pradel, P., Leotta, B., Priolo, A., \& Vasta, V. (2011). Effect of a HayBased Diet or Different Upland Grazing Systems on Milk Volatile Compounds. Journal of Agricultural and Food Chemistry, 59(9), 4947-4954.

Croissant, A. E., Washburn, S. P., Dean, L. L., \& Drake, M. A. (2007). Chemical Properties and Consumer Perception of Fluid Milk from Conventional and Pasture-Based Production Systems. Journal of Dairy Science, 90(11), 4942-4953.

Daniel, J., Amaral, R., Goulart, R., Zopollatto, M., Santos, V., Toledo Filho, S., Cabezas-Garcia, E., Lima, J., Santos, M., \& Nussio, L. (2013). Short-term effects of silage volatile compounds on feed intake and digestion in beef cattle. Journal of Animal Science, 91(5), 2321-2331.

Daniel, J., Amaral, R., Goulart, R., Zopollatto, M., Santos, V. P., Toledo Filho, S. G., CabezasGarcia, E. H., Lima, J. R., Santos, M. C., \& Nussio, L. G. (2013). Short-term effects of 
silage volatile compounds on feed intake and digestion in beef cattle1. Journal of Animal Science, 91(5), 2321-2331.

Davis, S., \& Collier, R. J. (1985). Mammary blood flow and regulation of substrate supply for milk synthesis. Journal of Dairy Science, 68(4), 1041-1058.

Elgersma, A., Ellen, G., Dekker, P., Van der Horst, H., Boer, H., \& Tamminga, S. (2003). Effects of perennial ryegrass (Lolium perenne) cultivars with different linolenic acid contents on milk fatty acid composition. Aspects of Applied Biology(70), 107-114.

Elmore, J., Mottram, D., Enser, M., \& Wood, J. (2000). The effects of diet and breed on the volatile compounds of cooked lamb. Meat Science, 55(2), 149-159.

Elmore, J. S., Warren, H. E., Mottram, D. S., Scollan, N. D., Enser, M., Richardson, R. I., \& Wood, J. D. (2004). A comparison of the aroma volatiles and fatty acid compositions of grilled beef muscle from Aberdeen Angus and Holstein-Friesian steers fed diets based on silage or concentrates. Meat Science, 68(1), 27-33.

Erasmus, S. W., Muller, M., Alewijn, M., Koot, A. H., van Ruth, S. M., \& Hoffman, L. C. (2017). Proton-transfer reaction mass spectrometry (PTR-MS) for the authentication of regionally unique South African lamb. Food Chemistry, 233, 331-342.

Fedele, V., Rubino, R., Claps, S., Sepe, L., \& Morone, G. (2005). Seasonal evolution of volatile compounds content and aromatic profile in milk and cheese from grazing goat. Small Ruminant Research, 59(2-3), 273-279.

Fischer, S., Trefz, P., Bergmann, A., Steffens, M., Ziller, M., Miekisch, W., Schubert, J. S., Köhler, H., \& Reinhold, P. (2015). Physiological variability in volatile organic compounds (VOCs) in exhaled breath and released from faeces due to nutrition and somatic growth in a standardized caprine animal model. Journal of Breath Research, 9(2), 027108.

Galle, S. A., Koot, A., Soukoulis, C., Cappellin, L., Biasioli, F., Alewijn, M., \& van Ruth, S. M. (2011). Typicality and Geographical Origin Markers of Protected Origin Cheese from The Netherlands Revealed by PTR-MS. Journal of Agricultural and Food Chemistry, 59(6), 2554-2563.

Gandy, A. L., Schilling, M., Coggins, P., White, C., Yoon, Y., \& Kamadia, V. (2008). The effect of pasteurization temperature on consumer acceptability, sensory characteristics, volatile compound composition, and shelf-life of fluid milk. Journal of Dairy Science, 91(5), 1769-1777.

Hafner, S. D., Howard, C., Muck, R. E., Franco, R. B., Montes, F., Green, P. G., Mitloehner, F., Trabue, S. L., \& Rotz, C. A. (2013). Emission of volatile organic compounds from silage: Compounds, sources, and implications. Atmospheric Environment, 77, 827-839.

Hansen, B., Alrøe, H. F., \& Kristensen, E. S. (2001). Approaches to assess the environmental impact of organic farming with particular regard to Denmark. Agriculture, Ecosystems \& Environment, 83(1-2), 11-26. 
Heil, M. (2008). Indirect defence via tritrophic interactions. New Phytologist, 178(1), 41-61.

Holzinger, R. (2015). PTRwid: A new widget tool for processing PTR-TOF-MS data. Atmospheric Measurement Techniques, 8(9), 3903-3922.

Joost, A. d. G., Carleton, J. H., Thomas, G. C., \& Fall, R. (1999). Emissions of volatile organic compounds from cut grass and clover are enhanced during the drying process. Geophysical Research Letters, 26(7), 811-814.

Kirsti, W., Galbally, I., Ye, Y., \& Hooper, M. (1998). Emissions of volatile organic compounds (primarily oxygenated species) from pasture. Journal of Geophysical Research: Atmospheres, 103(D9), 10605-10619.

Koss, A. R., Sekimoto, K., Gilman, J. B., Selimovic, V., Coggon, M. M., Zarzana, K. J., Yuan, B., Lerner, B. M., Brown, S. S., \& Jimenez, J. L. (2018). Non-methane organic gas emissions from biomass burning: identification, quantification, and emission factors from PTR-ToF during the FIREX 2016 laboratory experiment. Atmospheric Chemistry and Physics, 18(5), 3299.

Liu, N., Koot, A., Hettinga, K., de Jong, J., \& van Ruth, S. M. (2018). Portraying and tracing the impact of different production systems on the volatile organic compound composition of milk by PTR-(Quad)MS and PTR-(ToF)MS. Food Chemistry, 239, 201207.

Liu, N., Pustjens, A. M., Erasmus, S. W., Yang, Y., Hettinga, K., \& van Ruth, S. M. (2020). Dairy farming system markers: The correlation of forage and milk fatty acid profiles from organic, pasture and conventional systems in the Netherlands. Food Chemistry, 314, 126153

Mäder, P., Fliessbach, A., Dubois, D., Gunst, L., Fried, P., \& Niggli, U. (2002). Soil fertility and biodiversity in organic farming. Science, 296(5573), 1694-1697.

Malkina, I. L., Kumar, A., Green, P. G., \& Mitloehner, F. M. (2011). Identification and quantitation of volatile organic compounds emitted from dairy silages and other feedstuffs. Journal of environmental quality, 40(1), 28-36.

Mochalski, P., King, J., Klieber, M., Unterkofler, K., Hinterhuber, H., Baumann, M., \& Amann, A. (2013). Blood and breath levels of selected volatile organic compounds in healthy volunteers. Analyst, 138(7), 2134-2145.

O'mara, F., Fitzgerald, J., Murphy, J., \& Rath, M. (1998). The effect on milk production of replacing grass silage with maize silage in the diet of dairy cows. Livestock Production Science, 55(1), 79-87.

Phillips, M., Greenberg, J., \& Awad, J. (1994). Metabolic and environmental origins of volatile organic compounds in breath. Journal of clinical pathology, 47(11), 1052-1053.

Pickett, J. A., \& Khan, Z. R. (2016). Plant volatile-mediated signalling and its application in agriculture: successes and challenges. New Phytologist, 212(4), 856-870. 
Poisson, N., Kanakidou, M., \& Crutzen, P. J. (2000). Impact of non-methane hydrocarbons on tropospheric chemistry and the oxidizing power of the global troposphere: 3dimensional modelling results. Journal of Atmospheric Chemistry, 36(2), 157-230.

Sakatani, M., Balboula, A. Z., Yamanaka, K., \& Takahashi, M. (2012). Effect of summer heat environment on body temperature, estrous cycles and blood antioxidant levels in Japanese Black cow. Animal Science Journal, 83(5), 394-402.

Satpute, D., Padghan, P., Patil, Y., \& Patil, R. (2017). Studies on Organoleptic Properties of Herbal Whey Based Beverage.

Sintamarean, I.-M. (2017). Feedstock preparation and physico-chemical characterization. Optimization of feedstocks for continuous HTL and optimum yield. Bulletin of Environment, Pharmacology and Life Sciences, 7(1), 11-16

Toso, B., Procida, G., \& Stefanon, B. (2002). Determination of volatile compounds in cows' milk using headspace GC-MS. Journal of Dairy Research, 69(4), 569-577.

Tunick, M. H., Paul, M., Ingham, E. R., Karreman, H. J., \& Van Hekken, D. L. (2015). Differences in milk characteristics between a cow herd transitioning to organic versus milk from a conventional dairy herd. International Journal of Dairy Technology, 68(4), 511-518.

Vallejo-Cordoba, B., \& Nakai, S. (1994). Keeping-Quality Assessment of Pasteurized Milk by Multivariate Analysis of Dynamic Headspace Gas Chromatographic Data. 1. Shelf-Life Prediction by Principal Components Regression. Journal of Agricultural and Food Chemistry, 42(4), 989-993.

van Ruth, S. M., Silvis, I. C., Alewijn, M., Liu, N., Jansen, M., \& Luning, P. A. (2019). No more nutmegging with nutmeg: Analytical fingerprints for distinction of quality from low-grade nutmeg products. Food Control, 98, 439-448.

Vasta, V., D’Alessandro, A. G., Priolo, A., Petrotos, K., \& Martemucci, G. (2012). Volatile compound profile of ewe's milk and meat of their suckling lambs in relation to pasture vs. indoor feeding system. Small Ruminant Research, 105(1-3), 16-21.

Villeneuve, M. P., Lebeuf, Y., Gervais, R., Tremblay, G. F., Vuillemard, J. C., Fortin, J., \& Chouinard, P. Y. (2013). Milk volatile organic compounds and fatty acid profile in cows fed timothy as hay, pasture, or silage. Journal of Dairy Science, 96(11), 7181-7194.

Waldo, D., \& Schultz, L. (1956). Lactic acid production in the rumen. Journal of Dairy Science, 39, 1453-1460.

Wojnowski, W., Majchrzak, T., Szweda, P., Dymerski, T., Gębicki, J., \& Namieśnik, J. (2018). Rapid Evaluation of Poultry Meat Shelf Life Using PTR-MS. Food Analytical Methods, 1-8.

Yasuko, U., Sadaki, A., Makoto, M., \& Fumiaki, A. (2016). Effect of time at pasture and herbage intake on profile of volatile organic compounds of dairy cow milk. Animal Science Journal, 87(1), 117-125. 
Young, O., \& Baumeister, B. (1999). The effect of diet on the flavour of cooked beef and the odour compounds in beef fat. New Zealand Journal of Agricultural Research, 42(3), 297-304. 


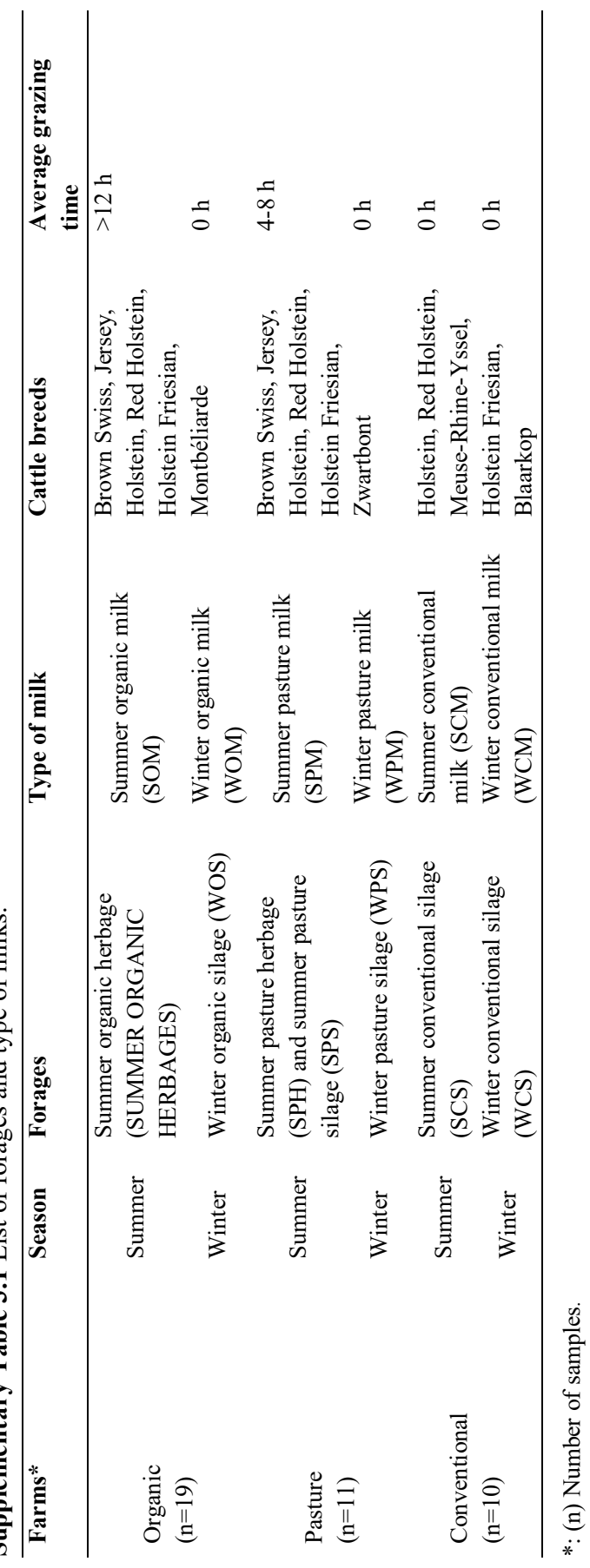


CHAPTER 3 


\section{Chapter 4 \\ Evaluation of portable near-infrared spectroscopy for organic milk authentication}

This chapter was published as: Ningjing Liu, Hector Aya Parra, Annemieke M. Pustjens, Kasper Hettinga, Philippe Mongondry, Saskia M. van Ruth, Evaluation of portable nearinfrared spectroscopy for organic milk authentication, Talanta, Volume 184, 2018, 128-135. 


\begin{abstract}
Organic products are vulnerable to fraud due to their premium price. Analytical methodology helps to manage the risk of fraud and due to the miniaturization of equipment, tests may nowadays even be rapidly applied on-site. The current study aimed to evaluate portable near infrared spectroscopy (NIRS) in combination with chemometrics to distinguish organic milk from other types of milk, and compare its performance with benchtop NIRS and fatty acid profiling by gas chromatography. The sample set included 37 organic retail milks and 50 non-organic retail milks (of which 36 conventional and 14 green 'pasture' milks). Partial least squares discriminant analysis was performed to build classification models and kernel density estimation (KDE) functions were calculated to generate non-parametric distributions for samples' class probabilities. These distributions showed that portable NIRS was successful to distinguish organic milks from conventional milks, and so were benchtop NIRS and fatty acid profiling procedures. However, it was less successful when 'pasture' milks were considered too, since their patterns occasionally resembled those of the organic milk group. Fatty acid profiling was capable of distinguishing organic milks from both non-organic milks though, including the 'pasture' milks. This comparative study revealed that the classification performance of the portable NIRS for this application was similar to that of the benchtop NIRS.
\end{abstract}

Keywords: Authentication; Class probability; FT-NIRS; Micro-NIRS; Organic milk 


\subsection{Introduction}

The appeal for organic milk has created a growing market share in the last years. In this situation, many agricultural regions in the world have experienced an organic revolution to respond to this demand. In 2015 , up to $12 \%$ of all dairy sales belonged to the organic dairy market in the EU (Willer \& Lernoud, 2017). The production of organic milk was 4.4 million metric tons in 2015, which is almost double the volume of 2007. However, there is still insufficient supply due to limited production in organic systems. Meanwhile, organic milk retails at a premium price due to the higher production costs (McFadden \& Huffman, 2017). These two aspects make organic milk susceptible to fraud. Vulnerability studies of the liquid milk supply chain showed that there is limited implementation of fraud control measures in this chain in general (van Ruth, Luning, Silvis, et al., 2018). Part of these potential measures are fraud monitoring systems. These systems require adequate methods, both in the laboratory and beyond.

Different approaches have been developed to detect some potential biomarkers for organic milk authentication such as for iodine (Payling, Juniper, Drake, et al., 2015), and carbon and nitrogen isotopes (Erich, Schill, Annweiler, et al., 2015). In addition, some other studies have focused on untargeted fingerprints to assure the authenticity of organic products in the dairy sector based, which were based on fatty acids (FAs) profiles (Capuano, Grevink, Boerrigter-Eenling, et al., 2015; Capuano, van der Veer, Boerrigter-Eenling, et al., 2014). These approaches have demonstrated accurate results after a series of complex sample preparation steps and professional instrument operation. Nevertheless, the market still demands faster and cheaper methods which can be performed (preferably on-site) by different tiers in the supply chain, including farmers, processors, retailers, and possibly even consumers (Ellis, Muhamadali, Haughey, et al., 2015). From this point of view, the portability and operability are important aspects to consider too.

Near-infrared spectroscopy (NIRS) as a fast, non-destructive method may be an interesting solution. This technique observes the characteristic reflection and absorption spectra in the NIR region $(780-2500 \mathrm{~nm})$. The valuable information in these spectra relates to overtones and combinations of vibrations of some characteristic bonds, such as $\mathrm{C}-\mathrm{H}, \mathrm{N}-\mathrm{H}, \mathrm{O}-$ $\mathrm{H}$, and $\mathrm{S}-\mathrm{H}$, which typically exist in all organic molecules. NIRS has been widely accepted and applied in food analysis (Capuano, Rademaker, van den Bijgaart, et al., 2014; Mabood, Jabeen, Ahmed, et al., 2017; Malegori, Nascimento Marques, de Freitas, et al., 2017). Furthermore, advanced techniques allow miniaturization of optical components without excessive loss of performance. These developments significantly improved the portability of NIRS systems. Some studies have been carried out to apply portable NIRS in food composition analysis including fruit ripening evaluation (Cirilli, Bellincontro, Urbani, et al., 2016; Malegori, et al., 2017), palm oil adulteration (Basri, Hussain, Bakar, et al., 2017), as well as feed safety 
(Haughey, Galvin-King, Malechaux, et al., 2015). Promising results were obtained in these studies by combining portable NIRS with suitable chemometrics.

When applying this methodology for distinguishing organic milk, it is importance to realize that in the Netherlands, there is so-called green milk ('pasture milk') which promotes the idea of being more natural through regular grazing of the cattle. In this system, cows have to be outside at least 120 days per year, for $6 \mathrm{~h}$ per day. It is relevant to consider pasture milk when comparing milk from the organic and conventional systems, because its composition may be somewhat similar to organic milk (Capuano, et al., 2015; Liu, Koot, Hettinga, et al., 2018).

The aim of the current study was to evaluate portable NIRS in combination with chemometrics to distinguish organic milk from other types of milk (conventional and pasture milks), and compare its performance with benchtop NIRS and fatty acid profiling by gas chromatography.

\subsection{Materials and methods}

\subsubsection{Milk samples}

A total of 87 cartons of full-fat, pasteurized retail milks were collected from supermarkets in the Wageningen area, Gelderland region, in the Netherlands during a period of eight weeks between May and June of 2016. The sample set included 37 organic retail milks (OM) from five brands and 50 non organic retail milks (NOM). The latter comprised 36 conventional retail milks $(\mathrm{CM})$ from six brands and 14 pasture retail milks (PM) from two brands. Samples were analysed by a portable and benchtop NIRS on the day of purchase or the first consecutive day after purchase, and an aliquot of each sample was stored at $-18{ }^{\circ} \mathrm{C}$ for fatty acid analysis later.

\subsubsection{Portable NIRS: Micro-NIRS}

An ultra-compact spectrometer, Micro-NIR 1700 (JDSU, Milpitas, CA/USA) with a spectral working range of $908-1676 \mathrm{~nm}$ and a $6 \mathrm{~nm}$ sampling step was selected as the portable NIRS instrument to collect the spectrometric data. The reflectance mode was selected according to default settings. The spectrometer employs a linear variable filter (LVF) as the light dispersing element and is powered by USB (500mA, 5V). Three ml of each milk sample was taken to a $4 \mathrm{ml}$ vial (Sun Sri, Wilmington, NC, USA) and analyses were carried out in triplicate. Triplicate readings were averaged for further data analysis.

\subsubsection{Benchtop NIRS: FT-NIRS}

A NIRFlex N-500 benchtop instrument (Buchi AG, Flawil, Switzerland) was used to generate the FT-NIR spectral data. The spectrometer was equipped with six glass cuvettes (light path $2 \mathrm{~mm}$ ) (QX 2.0mm, Hellma Analytics, Müllheim, Germany). Each sample was scanned in the range of 1000-2500 $\mathrm{nm}$ with the transmission mode as default settings. A reference standard 
was measured before each serie to calibrate the spectrometer. Each sample was analysed in triplicate and placed randomly in different cuvettes during each serie. Triplicate readings were averaged for further data analysis.

\subsubsection{FA by Gas Chromatography (GC)}

The FA compositions of the milk samples were determined by a GC16958 (Agilent 7890A, Agilent Technologies, Palo Alto, CA, US) according to NEN-ISO 1740:2004 | IDF 6as fatty acid methyl esters (FAMEs) (Pustjens, Boerrigter-Eenling, Koot, et al., 2017). The GC was equipped with a $100 \mathrm{~m} \times 0.25 \mathrm{~mm} \times 0.2 \mu \mathrm{m}$ film thickness fused silica capillary column (Varian, Palo Alto, CA) coupled to a flame ionization detector (column temperature $275^{\circ} \mathrm{C}$ ). All the chemicals were ACS grade, and purchased from Sigma-Aldrich (St. Louis, MO, USA). A volume of $2 \mathrm{ml}$ milk was weighted in a $30 \mathrm{ml}$ sterile, screw top plastic bottle, mixed with 5 $\mathrm{ml}$ internal standard solution (500 mg of C13:0 triglyceride and 500 $\mathrm{mg}$ of C11:0 FAME in 250 $\mathrm{ml}$ tert-butyl methyl ether. To start the transesterification, $5 \mathrm{ml}$ methanolic sodium methoxide solution $(5 \%, \mathrm{~m} / \mathrm{v})$ was added, and $2 \mathrm{ml}$ hexane and $10 \mathrm{ml}$ neutralization solution were added after 180 seconds and 210 seconds, respectively. The mixture was vortexed for 30 seconds and then centrifuged for 5 minutes, and $1 \mathrm{ml}$ of supernatant was removed with a pipette into GC amber glass vials. Each sample was weighed and measured in duplicate. Since spectrometry has a better correlation with FA concentrations in milk instead of concentrations in milk fat (Soyeurt, Dardenne, Dehareng, et al., 2006), the concentrations of FA in this research were expressed as $\mu \mathrm{g} / 100 \mathrm{~g}$ liquid milk. Average values of the duplicates were used for further data analysis.

\subsubsection{Statistical analysis}

Univariate analysis was applied to the FA dataset, but FAs concentrations were firstly tested for normality by using Shapiro-Wilk. As the data did not always show normal distribution, non-parametric Kruskal-Wallis tests were applied for group comparison followed by Mann-Whitney U-test for pairwise comparison (Bogue, Coleman, \& Sorenson, 2005). FAs with $\mathrm{P}<0.01$ after Benjamini-Hochberg $(\mathrm{BH})$ adjustment were indicated as statistically significant. Principal component analysis (PCA) was carried out to explore the three multivariate datasets acquired by Micro-NIRS, FT-NIRS, and FAs by GC separately. In order to eliminate the effects of noise and to balance the weights of different variables, all three datasets were pre-processed in various ways, including auto-scaling, mean-centering, smoothing, $1^{\text {st }}$ derivative, log 10 transformation, and multiple scattering correction (MSC). The best pre-processing combination was chosen for each dataset to get the best separated PCA distribution. The relationship between NIR spectra and FAs profiles was determined by computing the correlation coefficient between FAs concentrations and wavelength absorbances. 
Considering that a higher risk of overfitting will come with non-linear predicting algorithms, classification models were estimated by partial least squares discriminant analysis (PLS-DA) to discriminate (A) OM against CM, and (B) OM against the non-organic milks CM and PM. The data sets were randomly divided into two sub-sets, a training set $(70 \%$ of the samples of each class) and an external validation set (the remaining 30\% of the samples). The training set was used to build models and internally validate the models by 500 times repeated leave- $20 \%$ out cross-validation. The external validation set was used to externally validate the models after the internal validation. The performance of classification models was measured according to several parameters, including: accuracy, the overall rate of correct classification; sensitivity, the rate of correct identification; specificity, and the rate of correct rejection (Kuhn \& Johnson, 2013). In our research, correct identification refers to organic milk that would be correctly classified, while correct rejection refers to non-organic milk that would be correctly classified. Besides a binary classification, all the samples were also scored by the class probability valued from 0 (OM identified) to 1 (OM rejected) and kernel density estimation (KDE) functions were applied to generate a non-parametric distribution for samples' class probability (Alewijn, van der Voet, \& van Ruth, 2016). Compared with binary results, the quantitative scores of class probability is more informative and could solve the problem of resolution caused by smaller sample sets. To evaluate the discrimination capacity of models built from the three datasets (Micro-NIRS vs FT-NIRS, Micro-NIRS vs FAs, and FT-NIRS vs FAs), Passing-Bablok linear regression models (Passing \& Bablok, 1983) were built. A joint test was performed to investigate if slopes $=1$ and intercepts $=0$ at a $95 \%$ confidence level. The acceptance of the null hypothesis $\left(\mathrm{H}_{0}\right)$ meant there was no difference between the two investigated approaches (Malegori, et al., 2017). All the analyses were conducted by Pirouette 4.5 (Infometrix, WA, USA) and R 3.2.3 (R Foundation for Statistical Computing, Vienna, Austria).

\subsection{Results and discussion}

\subsubsection{Spectral features: Micro-NIRS and FT-NIRS}

All samples were subjected to spectroscopy analyses by Micro-NIRS and FT-NIRS. The average spectra obtained by Micro-NIRS and FT-NIRS are presented in Fig. 1a and b, respectively. The spectra differ due to instrument specific traits (e.g. different optical path length (García Martín, 2015)) and mode of application (reflectance/transmission). In the spectra acquired by Micro-NIRS, as shown is Fig. 4.1a, the wavelength range 1220-1390 nm shows largest separation between the groups of samples. The peak around $1340 \mathrm{~nm}$ relates to the presence of the combination of methyl $\left(-\mathrm{CH}_{3}\right)$ and methylene $\left(-\mathrm{CH}_{2}\right)$ groups (Westad, Schmidt, $\&$ Kermit, 2008). The peak at around $1510 \mathrm{~nm}$ is caused by the stretching of methyl (C-H). These bonds are likely to be strongly related to the concentration of different FAs. In the spectra acquired by FT-NIRS, as shown is Fig. $4.1 \mathrm{~b}$, there are two main ranges where samples show 
separation, i.e. in the $1492-1887 \mathrm{~nm}$ and 2083-2381 nm ranges. The peak in the $2240-2360 \mathrm{~nm}$ range originates from the stretching of the methyl and methylene groups, while the peak near $1725 \mathrm{~nm}$ and $1760 \mathrm{~nm}$ is the first overtone (vibration) of methyl $\left(-\mathrm{CH}_{3}\right)$, methylene $\left(-\mathrm{CH}_{2}\right)$, and ethenyl $(\mathrm{CH}=\mathrm{CH}-)$ groups (Westad, et al., 2008). The ethenyl group expresses the degree of unsaturation of the fatty acids. Monounsaturated fatty acids (MUFAs), such as oleic acid (C18:1), tend to show a peak around 1725 nm (Hourant, Baeten, Morales, et al., 2000).
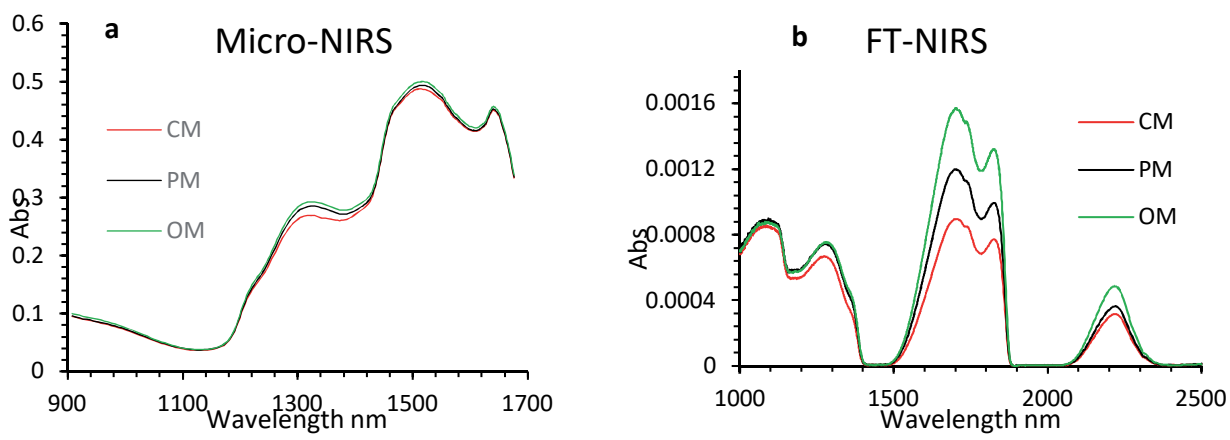

Fig. 4.1 Mean NIR spectra of organic milk (OM), pasture milk (PM), and conventional milk (CM) acquired by Micro-NIRS (a) and FT-NIRS (b).

To obtain an overview of the differences of different type of milk, raw Micro-NIR spectra and raw FT-NIR spectra were subjected to PCA after pre-processing. The optimized pre-processing methods for Micro-NIR spectrum and raw FT-NIR spectrum are as follows: (1) Micro-NIR spectral data are subjected to $\log 10$ transformation, mean-centering, MSC, and $1^{\text {st }}$ derivative; (2) FT-NIR spectral data are subjected to mean-centering, smoothing, MSC, and $1^{\text {st }}$ derivative. The scores distribution of the samples is presented in Fig. 4.2, which shows that OM and CM are relatively well separated, whereas PM is more widely spread, overlapping with the two other groups. This phenomenon can be explained by the more diverse management of PM. According to the rules, cows producing PM should be outside at least 4 hours per day for at least 120 days per year, which may lead to large variation in fresh grass consumption and thereby milk composition. In Fig. 4.2a (Micro-NIRS), the first two principal components (PCs) explain $92 \%$ of total variance, whereas in Fig. $4.2 \mathrm{~b}$ (FT-NIRS), the first two PCs only explain $35 \%$ of total variance. This is most likely due to the larger wavelength range of the FT-NIRS, which comprises more multidirectional variance between samples. Apparently, this larger variance cannot be reflected well by only two principal components.

\subsubsection{FAs profiles by GC}

All milks were analysed for their FA compositions. Since the concentrations of FAs were not normally distributed, non-parametric statistics were applied. There were 26 FAs selected with significantly different $(\mathrm{P}<0.01)$ concentrations between milk types (KruskalWallis test, Table 4.1). Among these 26 FAs, the three most abundant FAs were C16:0 (palmitic 
acid), C18:1n9c (oleic acid), and C14:0 (myristic acid), together accounting for more than 50\% of total FAs. Similar dominant FAs were also found by Capuano, et al. (2015). CM had significantly higher concentrations of these three FAs, compared with the other two types of milk.
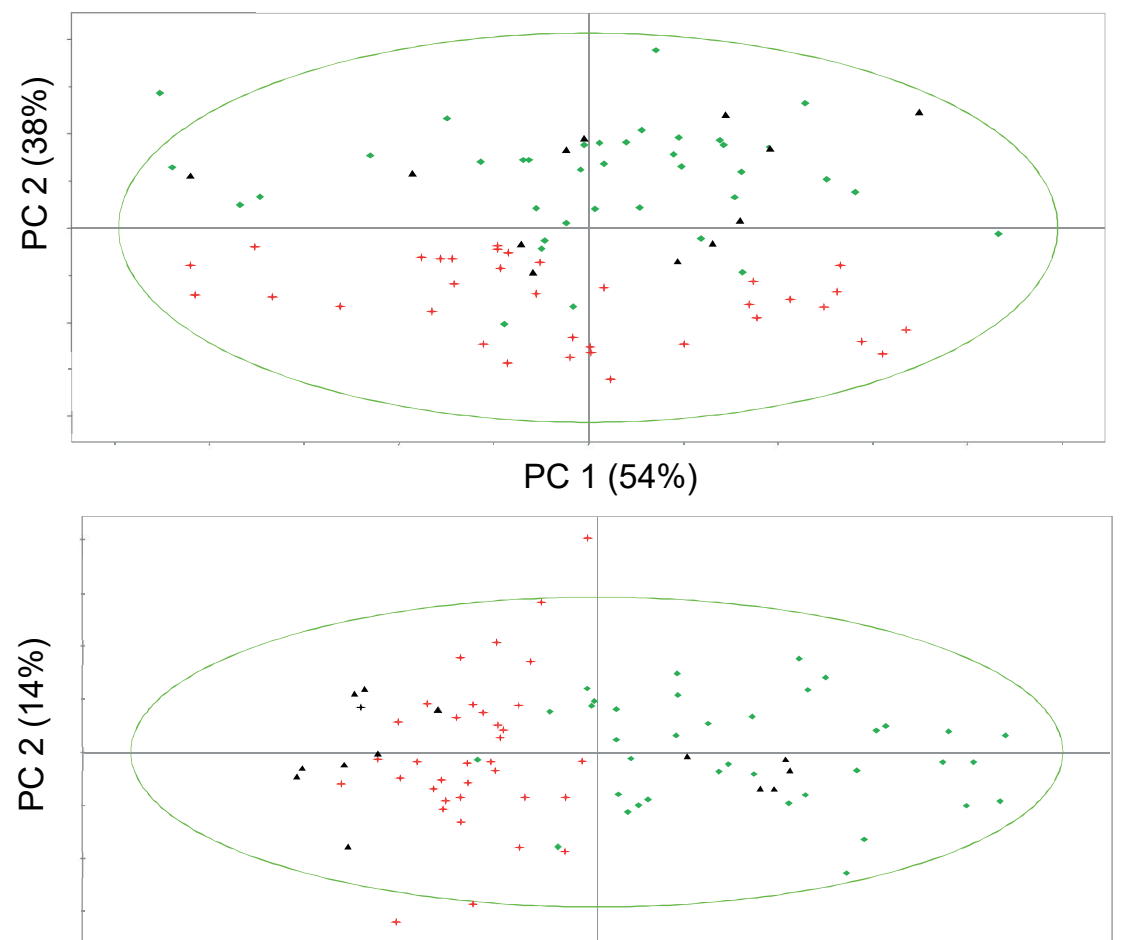

PC $1(21 \%)$

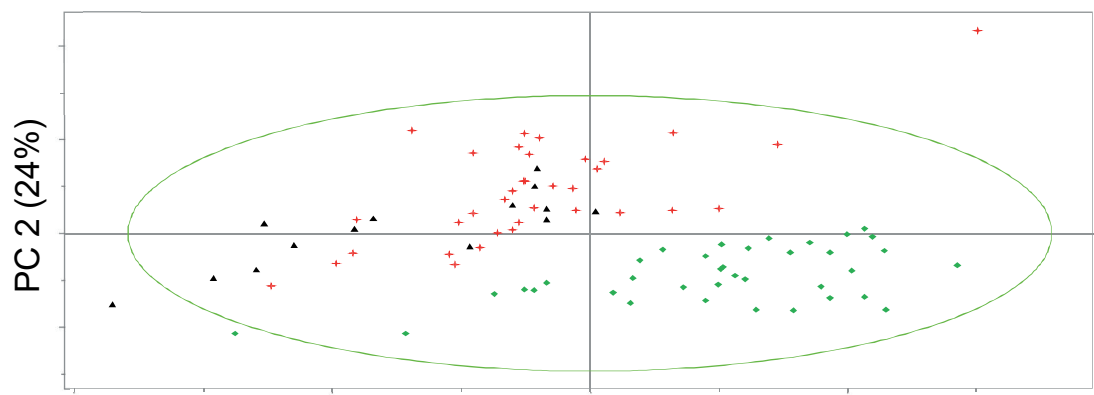

PC $1(35 \%)$

Fig. 4.2 Scores plots of the first two dimensions of PCA of OM (green diamond), PM (black triangle), and CM (red star) based on the data obtained from different instruments: Micro-NIRS (a), FT-NIRs (b), FAs by GC (c). 
Table 4.1 Average composition of FAs in organic (OM), pasture (PM), and conventional (CM) whole milks $(\mu \mathrm{g} / 100 \mathrm{~g}$ liquid milk): mean concentrations, standard deviations in brackets, and statistical relevance of differences between milk types $(\mathrm{P})^{\mathrm{x}}$.

\begin{tabular}{|c|c|c|c|c|}
\hline Fatty acid & OM & PM & CM & $\mathbf{P}$ \\
\hline $\mathrm{C} 4: 0$ & 135.8(9.7)ab & $130.6(10.4) b$ & $140.3(6.7) \mathrm{a}$ & $0.008^{*}$ \\
\hline C6:0 & $72.7(3.2) \mathrm{a}$ & $69.6(5) a$ & $73.6(3.8) \mathrm{a}$ & 0.049 \\
\hline C8:0 & $41.7(1.6) \mathrm{a}$ & $38.8(2.7) b$ & 41.1(2.3)ab & $0.002 *$ \\
\hline C10:0 & $93.7(3.8) \mathrm{a}$ & $85.9(5.4) b$ & $90.7(6.1) \mathrm{ab}$ & $<0.001^{*}$ \\
\hline C11:0 & $495.2(22.4) \mathrm{a}$ & 495.6(4.6)a & $498.8(14.2) \mathrm{a}$ & 0.33 \\
\hline C12:0 & $105.2(4.3) \mathrm{b}$ & $109.4(6.7) \mathrm{b}$ & 115.7(12.5)a & $<0.001^{*}$ \\
\hline C13:0 & $6.2(0.4) \mathrm{a}$ & $5.9(0.3) \mathrm{a}$ & $6.2(0.5) \mathrm{a}$ & 0.038 \\
\hline C14:0 & $324.2(12) b$ & $318.8(18.1) b$ & $337.7(19.5) \mathrm{a}$ & $0.001 *$ \\
\hline $\mathrm{C} 14: \ln 5$ & $27.4(1.3) \mathrm{c}$ & $29.2(1.5) b$ & $31.2(1.9) \mathrm{a}$ & $<0.001^{*}$ \\
\hline C15:0 & $34.7(1.8) \mathrm{a}$ & $30.5(1.8) \mathrm{c}$ & $32.6(2) \mathrm{b}$ & $<0.001^{*}$ \\
\hline $\mathrm{C} 15: \ln 5$ & $0.2(0.2) \mathrm{a}$ & $0.2(0.1) \mathrm{a}$ & $0.3(0.2) \mathrm{a}$ & 0.692 \\
\hline C16:0 & $798.5(38.7) b$ & 838.4(40.9)b & $876.1(60) \mathrm{a}$ & $<0.001 *$ \\
\hline $\mathrm{C} 16: \ln 7$ & $39.5(5.4) \mathrm{b}$ & $44.3(6.4) \mathrm{a}$ & 43.5(8.6)a & $<0.001^{*}$ \\
\hline C17:0 & $19.9(2.3) \mathrm{a}$ & $16(1.2) \mathrm{b}$ & $16.1(2.9) \mathrm{b}$ & $<0.001^{*}$ \\
\hline $\mathrm{C} 17: \ln 7$ & $8(0.5) \mathrm{a}$ & $7.2(0.5) b$ & $7.4(0.4) \mathrm{b}$ & $<0.001^{*}$ \\
\hline C18:0 & $323.7(21.6) \mathrm{a}$ & $304.4(19) \mathrm{b}$ & $318.8(15.7) \mathrm{a}$ & $0.003 *$ \\
\hline $\mathrm{C} 18: \ln 9 \mathrm{t}$ & $338.4(21.7) \mathrm{a}$ & $321.9(20.3) \mathrm{a}$ & $336.4(16) \mathrm{a}$ & 0.028 \\
\hline $\mathrm{C} 18: \ln 9 \mathrm{c}$ & $644.1(50.8) b$ & $648.3(35.2) b$ & $688.2(39.7) \mathrm{a}$ & $<0.001 *$ \\
\hline $\mathrm{C} 18: 2 \mathrm{n} 6 \mathrm{t}$ & $26.8(19) \mathrm{a}$ & $17.8(11.4) \mathrm{a}$ & $18.9(10.1) \mathrm{a}$ & 0.041 \\
\hline $\mathrm{C} 18: 2 \mathrm{n} 6 \mathrm{c}$ & 51.1(19.9)a & $51.3(11.8) \mathrm{a}$ & $55.4(12.1) \mathrm{a}$ & 0.041 \\
\hline CLA & $30.9(6.2) \mathrm{a}$ & $17.9(2.2) \mathrm{b}$ & $18.8(5.4) \mathrm{b}$ & $<0.001 *$ \\
\hline C18:3n6 & $0.9(0.3) \mathrm{a}$ & $0.8(0.2) \mathrm{a}$ & $0.8(0.2) \mathrm{a}$ & 0.967 \\
\hline $\mathrm{C} 18: 3 \mathrm{n} 3$ & 24.6(1.9)a & $15.1(1.6) b$ & $16.4(1.4) b$ & $<0.001^{*}$ \\
\hline C20:0 & $4.9(0.4) \mathrm{a}$ & $4.4(0.3) \mathrm{b}$ & $4.6(0.4) b$ & $<0.001^{*}$ \\
\hline C20:1n9 & $1.3(0.1) \mathrm{a}$ & $1.3(0.1) \mathrm{a}$ & $1.3(0.1) \mathrm{a}$ & 0.39 \\
\hline $\mathrm{C} 20: 2 \mathrm{n} 6$ & $0.7(0.1) \mathrm{a}$ & $0.6(0) \mathrm{b}$ & $0.6(0.1) b$ & $<0.001 *$ \\
\hline C20:3n6 & $1.8(0.2) \mathrm{b}$ & $2.1(0.2) \mathrm{a}$ & $2.2(0.2) \mathrm{a}$ & $<0.001^{*}$ \\
\hline $\mathrm{C} 20: 3 \mathrm{n} 3$ & $0.3(0.1) \mathrm{a}$ & $0.2(0) \mathrm{b}$ & $0.2(0) b$ & $<0.001 *$ \\
\hline $\mathrm{C} 20: 4 \mathrm{n} 6$ & $3.9(0.2) \mathrm{a}$ & $3.8(0.3) \mathrm{a}$ & $3.9(0.4) \mathrm{a}$ & 0.57 \\
\hline $\mathrm{C} 22: 0$ & $4(0.4) \mathrm{a}$ & $2.9(0.3) \mathrm{c}$ & $3.2(0.2) \mathrm{b}$ & $<0.001^{*}$ \\
\hline $\mathrm{C} 22: \ln 9$ & $0.2(0) \mathrm{a}$ & $0.2(0.1) b$ & $0.2(0.1) \mathrm{b}$ & $0.001 *$ \\
\hline $\mathrm{C} 20: 5 \mathrm{n} 3$ & $2.6(0.3) \mathrm{a}$ & $1.8(0.2) \mathrm{c}$ & $2(0.2) b$ & $<0.001^{*}$ \\
\hline $\mathrm{C} 22: 2 \mathrm{n} 6$ & $1.7(0.2) \mathrm{a}$ & $1.3(0.2) \mathrm{c}$ & $1.5(0.2) b$ & $<0.001^{*}$ \\
\hline $\mathrm{C} 24: 0$ & $1.5(0.1) \mathrm{a}$ & $1.2(0.1) \mathrm{b}$ & $1.2(0.1) \mathrm{b}$ & $<0.001^{*}$ \\
\hline $\mathrm{C} 24: \ln 9$ & $0.3(0) \mathrm{a}$ & $0.2(0.1) \mathrm{b}$ & $0.2(0.1) \mathrm{b}$ & $<0.001^{*}$ \\
\hline C22:6n3 & $0.4(0.1) \mathrm{a}$ & $0.2(0.1) \mathrm{b}$ & $0.2(0.1) \mathrm{b}$ & $<0.001^{*}$ \\
\hline SFA & $2462.1(96.7) b$ & 2452.4(105.9)a & $2556.8(121) \mathrm{a}$ & $<0.001 *$ \\
\hline MUFA & $1059.6(71.4) b$ & $1052.9(55.7) \mathrm{b}$ & $1108.7(50.9) a$ & $<0.001^{*}$ \\
\hline PUFA & 145.7(11.9)a & $113.1(8.2) \mathrm{b}$ & $121.1(8.1) \mathrm{b}$ & $<0.001^{*}$ \\
\hline
\end{tabular}

${ }^{\mathrm{x}}$ An asterisk $\left(^{*}\right)$ and different superscripts in a row indicate significant differences (Kruskal-Wallis test, $\mathrm{P}<0.01)$. 
According to the result of pairwise comparison by Mann-Whitney U-test, OM had significantly different concentrations of 18 FAs, but only six of them had concentrations higher than $10 \mu \mathrm{g} / 100 \mathrm{~g}$. This result suggests that if the focus is just on those predominant compounds, OM could be hardly distinguished from the other types of milk. Because of the nutritional expectations from consumers, polyunsaturated fatty acids (PUFAs) have drawn public attention, especially long chain PUFAs, such as eicosapentaenoic acid (EPA; 20:5n3), docosahexaenoic acid (DHA; 22:6n3) (E1 Bacha, Nunes, \& Torres, 2014), and their precursor, alpha linolenic acid (ALA) (Burdge \& Calder, 2005). In our results, these four FAs, as well as the total amount of PUFAs were significantly higher in OM, which is in line with previous observations (Capuano, van der Veer, et al., 2014; Collomb, Bisig, Bütikofer, et al., 2008; Coppa, Ferlay, Borreani, et al., 2015; Coppa, Ferlay, Chassaing, et al., 2013; Delgadillo-Puga, Sanchez-Munoz, Nahed-Toral, et al., 2014; Larsen, Fretté, Kristensen, et al., 2012). However, this level of differences is thought to have limited impact on human health (Bauman \& Lock, 2006). On the other hand, CM and PM only had 9 and 6 discriminating FAs respectively. This means they showed fewer unique features than organic milk, according to the post hoc test in Table 4.1. This is due to the flexible rules of PM, making it more difficult to distinguish between CM and PM (Liu, et al., 2018).

\subsubsection{PCA and correlation of NIR spectral data and individual FAs}

To obtain an overview of the characteristics of different types of milk, after optimization of the data pre-processing the FA concentrations were subjected to PCA after auto-scaling. The distribution of PCA scores is shown in Fig. 4.2c. The first two principal components (PCs) explain $59 \%$ of total variance. The scores plot shows the distinction between OM and the other two types of milks. The CM and PM are mixed with each other, matching the results of the Mann-Whitney U-tests. Compared with Micro-NIRS and FT-NIRS, FAs profiles contained information that allowed better separation of OM. Although the peak regions in the NIR spectral data refer to $\mathrm{C}-\mathrm{C}, \mathrm{C}-\mathrm{O}$, and $\mathrm{C}-\mathrm{H}$ bonds, which are the major structural elements of FAs, the resolution is lower, because no individual FAs can be identified. Comparing the PCA scores plots from these three techniques showed distinct differences, with FA profiles showing the best separation between groups.

Fig. 4.3 presents the correlation between the spectral data obtained by Micro-NIRS and FT-NIRS on the one hand (horizontal), and FA profiles obtained by GC on the other hand (vertical). The Micro-NIR spectra show a more predominant correlation with the concentrations of the FAs C14:0, C14:1n5, C16:0, C18:1n9c, and C20:3n6. Combined with the results in Table 4.1, it was found that $\mathrm{C} 14: 0$ and $\mathrm{C} 16: 0$ were two highly abundant long chain saturated fatty acids, whereas $\mathrm{C} 18: 1 \mathrm{n} 9 \mathrm{c}$ is the most dominant unsaturated fatty acid in the milk. Wavelength ranges with higher correlation coefficients with the FAs appear in the range from $900-1470$ nm. Similar results are observed for FT-NIRS (Fig. 4.3b). For the FT-NIR spectral data, FAs 
showing higher correlation coefficient values with longer wavelength ranges (1700 - $2500 \mathrm{~nm})$ show similar patterns for shorter wavelength ranges $(1000-1700 \mathrm{~nm})$. This implies that signals in longer wavelength ranges may not provide extra information in addition to the signals in shorter wavelength ranges.

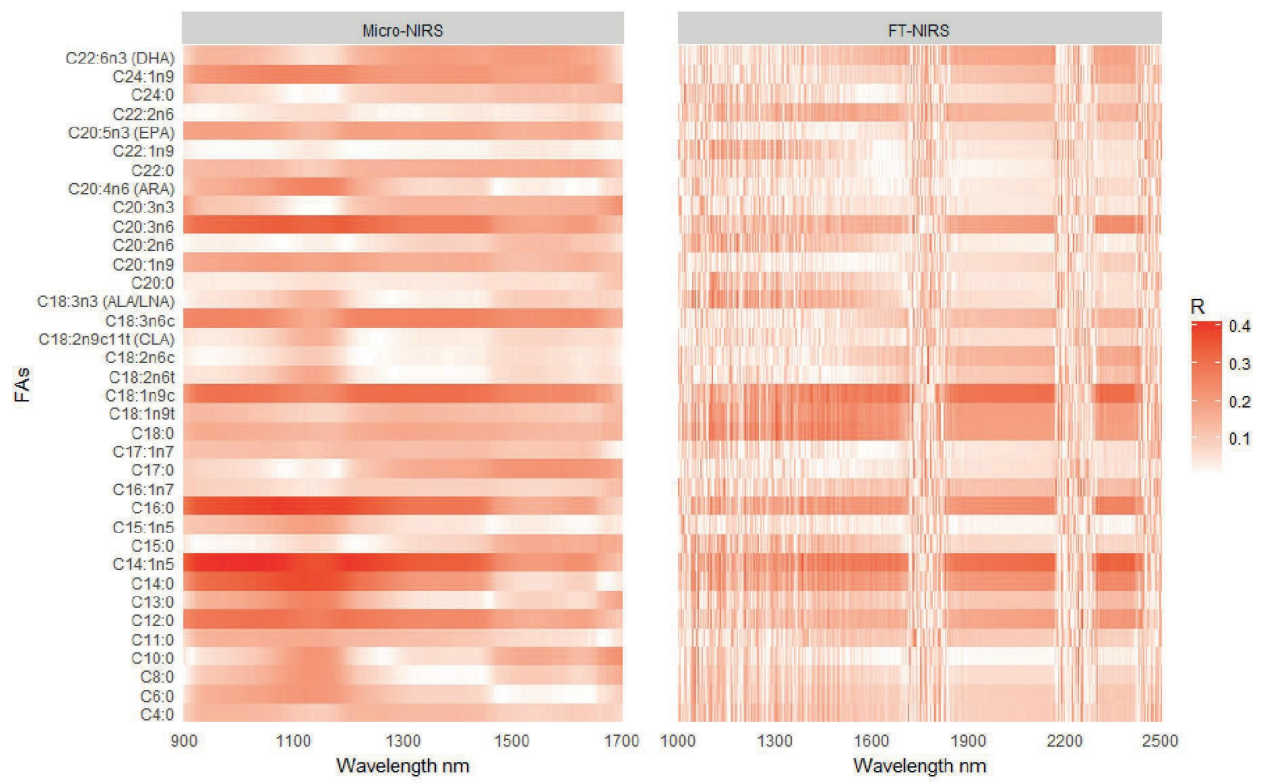

Fig. 4.3 Correlation coefficients for Micro-NIRS versus FAs by GC (a) and FT-NIRS versus FAs by GC (b).

\subsubsection{Classification models}

PLS-DA models were developed for the three datasets for two comparisons, (a) OM versus NOM (CM+PM); (b) OM versus $\mathrm{CM}$. The probability distributions of the two comparisons are presented in Fig. 4.4 and 5, respectively. Compared with binary models, KDE distribution plots provide more information than a single value (Alewijn, et al., 2016). Traditional binary models classify samples according to a threshold value. Samples with probability scores lower than the threshold value are classified in one group, while samples with probability scores higher than the threshold value are classified as the other group. Usually, the number of samples classified correctly will be presented. However, KDE distribution plots also show the difference between sample probability scores to the threshold value. The smaller the difference between probability scores and the threshold value, the higher the risk of misclassification. In this study, the threshold value was set as 0.5 by default, but it could be modified according to specific needs for future applications.

The Micro-NIRS dataset (Fig. 4.4a) shows two sub-groups in NOM, a larger sub-group on the right hand side of 0.5 and a smaller sub-group on the left hand side. Regardless of the 
smaller sub-group on the left, the larger sub-group seems well distributed. The tails at both sides are light and the location of the peak is far from the threshold value 0.5. Combining with the information of PM, the smaller sub-group on the left side is caused by PM samples. As regard to the distribution of OM, there are tails both at right and left hand sides, and the average score is close to the threshold value. With the removal of PM (Fig. 4.5a), the distribution of CM improves because the left hand side sub-group, represented by PM samples, vanishes. Therefore, OM and CM can be distinguished efficiently by Micro-NIRS, but PM is blurring the separation. Similar results were obtained from the FT-NIRS data (Fig. 4.4b/5b). With the removal of PM, the tails of the distribution of $\mathrm{CM}$ become lighter and the scores of most $\mathrm{CM}$ are higher than the threshold. For the FA by GC data, however, fairly perfect separation is observed for OM and NOM as well as OM and CM. Thus, the smaller FAs may play an important role in the separation of $\mathrm{OM}$ and $\mathrm{NOM}$, or alternatively other characteristics affect the NIRS results.

Classification results for Micro-NIRS, FT-NIRS, and FA by GC are summarized in Table 4.2. They confirm the KDE plots showing that both Micro-NIRS and FT-NIRS result in sufficient success for $\mathrm{OM}$ versus $\mathrm{CM}$ classifications, but is less successful when PM is considered too (OM versus NOM). On the other hand, FAs by GC is very suitable to distinguish both OM and NOM, as well as OM and CM.

The first five FAs with highest absolute loading scores in the model of OM versus NOM and the model of OM versus CM are ALA, EPA, C22:0, C18:2n9c11t, C24:0, and C14:1n5, $\mathrm{C} 20: 3 \mathrm{n} 6, \mathrm{C} 16: 0, \mathrm{C} 12: 0, \mathrm{C} 18: 1 \mathrm{n} 9 \mathrm{c}$, respectively. Combined with the correlation results in Fig. 4.3 , it is revealed that FAs with higher contribution to the model of OM versus CM also show higher correlation values than those FAs with higher contribution to the model of OM versus NOM. This may also explain the better performance of Micro-NIRS and FT-NIRS in differentiating OM versus CM, compared to OM versus NOM. Although the sensitivity of the models built by Micro-NIRS and FT-NIRS is not perfect, high specificity of the models ensures that there is low risk for $\mathrm{CM}$ to be classified as OM. 


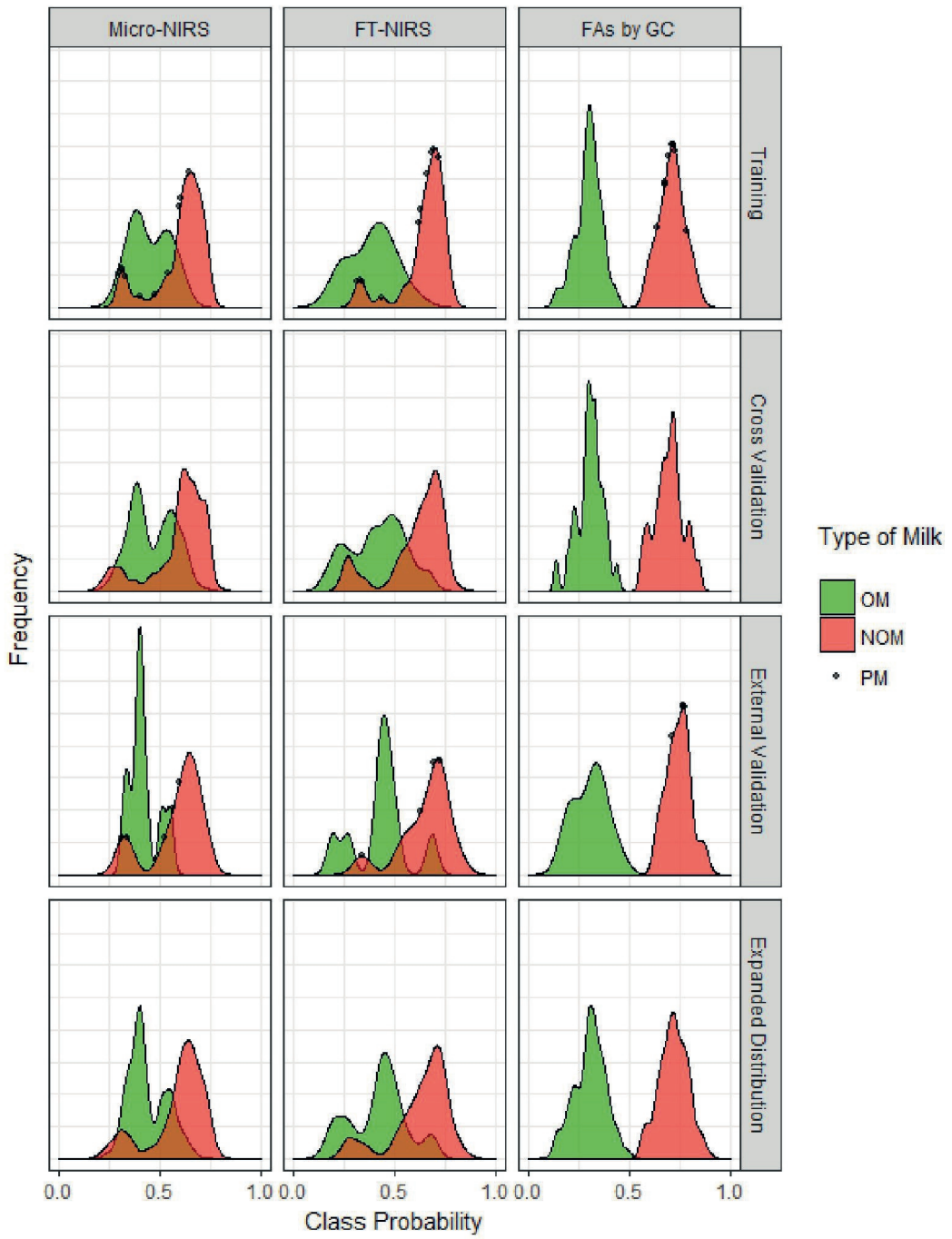

Fig. 4.4 Organic milk $(\mathrm{OM})$ vs non-organic milk (NOM) classification results (KDE) for the training set, internal validation set, external validation set, and for the expanded distribution for the Micro-NIRS (a), FT-NIRS (b), and FAs by GC (c) results. KDE displays the probability distributions for the OM (left, in green) and the NOM (right, in red) samples. Pasture milk (PM) samples are highlighted by black dots. 


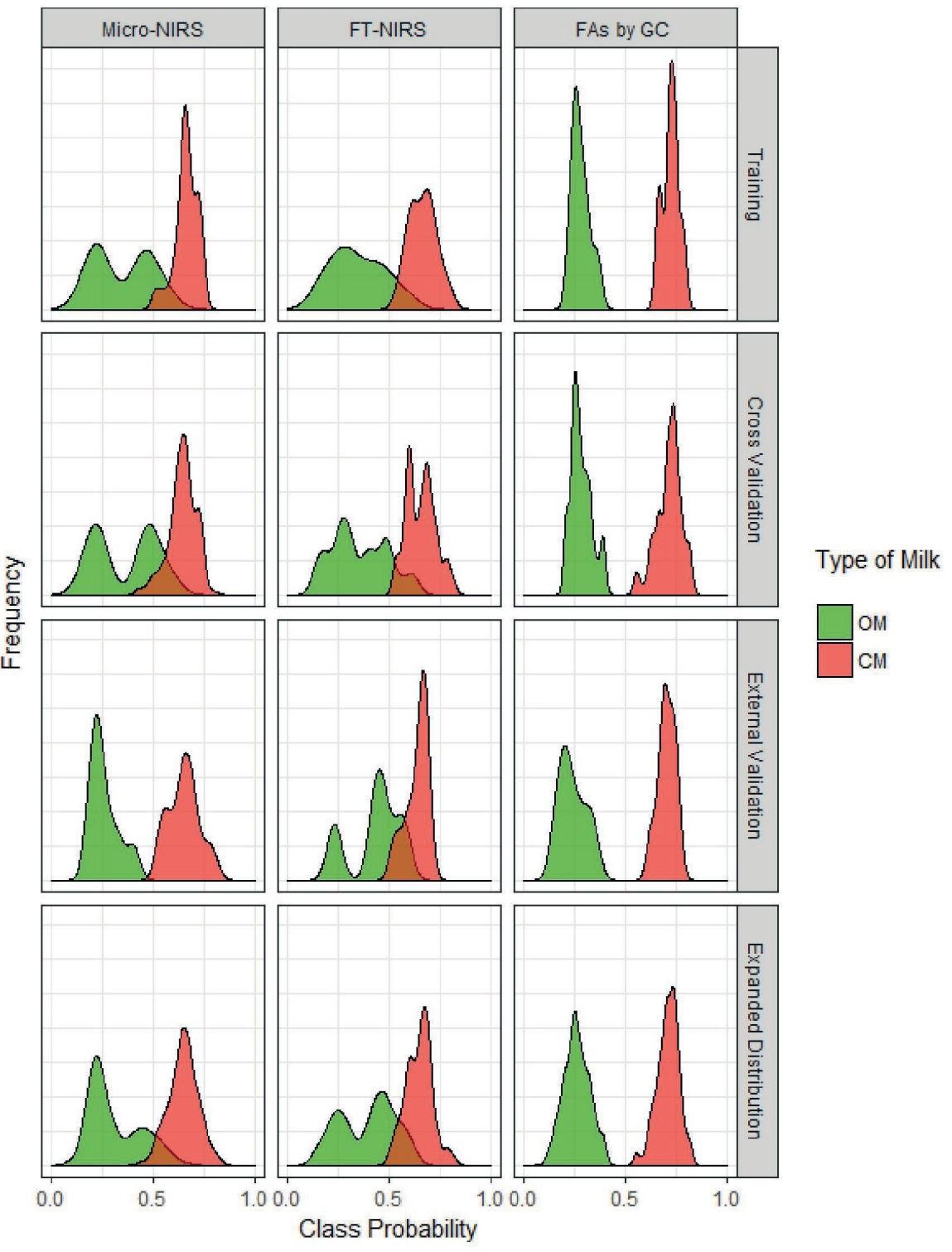

Fig. 4.5 Organic milk (OM) vs conventional milk (CM) classification results (KDE) for the training set, internal validation set, external validation set, and for the expanded distribution for the Micro-NIRS (a), FT-NIRS (b) and FAs by GC (c) results. KDE displays the probability distributions for the OM (left, in green) and the $\mathrm{CM}$ (right, in red) samples. 


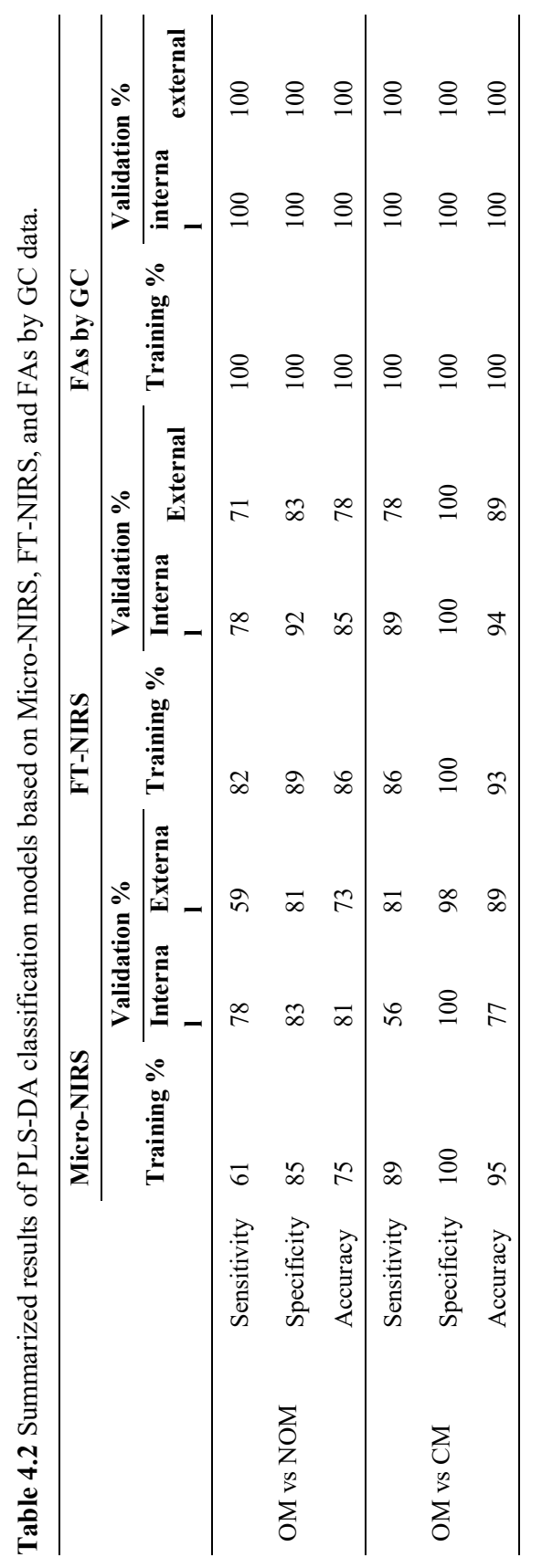


Table 4.3 Joint tests on slope and intercept by Passing-Bablok regression for class probabilities predicted for different group comparisons and analytical techniques ( $95 \%$ confidence).

\begin{tabular}{|c|c|c|c|c|}
\hline Group comparison & Technique & Slope & Intercept & Joint test $^{\text {a }}$ \\
\hline \multirow{3}{*}{ OM vs NOM } & $\begin{array}{l}\text { Micro-NIRS vs FAs } \\
\text { by GC }\end{array}$ & 1.4 & -0.24 & $\mathrm{H}_{0}$ rejected \\
\hline & $\begin{array}{l}\text { FT-NIRS vs FAs by } \\
\text { GC }\end{array}$ & 1.34 & -0.22 & $\mathrm{H}_{0}$ rejected \\
\hline & FT vs Micro-NIRS & 1.08 & -0.05 & $\mathrm{H}_{0}$ accepted \\
\hline \multirow{3}{*}{ OM vs CM } & $\begin{array}{l}\text { Micro-NIRS vs FAs } \\
\text { by GC }\end{array}$ & 1.09 & -0.04 & $\mathrm{H}_{0}$ accepted \\
\hline & $\begin{array}{l}\text { FT-NIRS vs FAs by } \\
\text { GC }\end{array}$ & 1.11 & -0.05 & $\mathrm{H}_{0}$ accepted \\
\hline & $\begin{array}{l}\text { FT-NIRS vs Micro- } \\
\text { NIRS }\end{array}$ & 0.97 & 0.02 & $\mathrm{H}_{0}$ accepted \\
\hline
\end{tabular}

${ }^{a}$ The null hypothesis is accepted when the predictability of the two approaches is statistically equivalent.

To determine if there exists any statistically different capability of prediction among the models based on Micro-NIRS, FT-NIRS and FAs by GC data, Passing-Bablok regression was applied (Malegori, et al., 2017). The results are shown in Table 4.3. The test shows that the models based on Micro-NIRS data and FT-NIRS data have an equivalent ability to predict the identity of OM samples versus NOM samples. This means they have similar capabilities. However, for the same type of prediction there is no equivalence between the results of the NIRS methods and FAs by GC. The three approaches have the same ability though to distinguish between OM and CM (without PM present). The main difference between MicroNIRS and FT-NIRS is the optical device. The Micro-NIRS instrument is equipped with a linear variable filter (LVF) whereas FT-NIRS is equipped with a Michelson interferometer. Compared with the Michelson interferometer, the LVF is tiny and can be easily interpreted, but the limitations of this optical device are the low resolution and wavelength shifts that may occur (Li, Huang, \& Zhang, 2017; Nogueira, Felps, \& Gutierrez-Osuna, 2007; Renhorn, Bergström, Hedborg, et al., 2016). Furthermore, the LVF applied in our research had a narrow wavelength range (908 -1676 nm). Despite these differences, classification results were similar. In other words, higher resolution and a wider wavelength range did not significantly promote the prediction ability. This could be due to several reasons. Firstly, higher resolution and a wider wavelength range do not make any differences in detecting low concentration compounds, like OM markers. Secondly, a certain correlation among the signals of different wavelengths may exist (Shi \& Yu, 2017), which is also shown in Fig. 4.3. In this case, wider wavelength range or more data points do not guarantee more information that can help to distinguish one group from another. 


\subsection{Conclusions}

Portable NIRS (Micro-NIRS) was shown to be able to distinguish between organic and conventional milks but will result in less successful class assignment for pasture milk samples. Benchtop NIRS (FT-NIRS) showed similar ability as Micro-NIRS to differentiate between milks. FAs by GC analysis allowed distinction of all groups well. Although not perfect, the portable NIRS shows potential as a first, on site check of the identity of organic milks, being non-inferior to benchtop NIRS for this application.

\subsection{Funding}

The first author received financially support for his $\mathrm{PhD}$ project by the China Scholarship Council.

\subsection{Acknowledgements}

The authors wish to acknowledge contributions made by Dr Martin Alewijn of RIKILT Wageningen University and Research who assisted with chemometric analyses in the initial phase of the data analyses. 


\subsection{References}

Alewijn, M., van der Voet, H., \& van Ruth, S. (2016). Validation of multivariate classification methods using analytical fingerprints - concept and case study on organic feed for laying hens. Journal of Food Composition and Analysis, 51, 15-23.

Basri, K. N., Hussain, M. N., Bakar, J., Sharif, Z., Khir, M. F. A., \& Zoolfakar, A. S. (2017). Classification and quantification of palm oil adulteration via portable NIR spectroscopy. Spectrochimica Acta Part A: Molecular and Biomolecular Spectroscopy, 173, 335-342.

Bauman, D., \& Lock, A. (2006). Conjugated linoleic acid: biosynthesis and nutritional significance. In Advanced Dairy Chemistry Volume 2 Lipids, (pp. 93-136): Springer.

Bogue, J., Coleman, T., \& Sorenson, D. (2005). Determinants of consumers' dietary behaviour for health-enhancing foods. British Food Journal, 107(1), 4-16.

Burdge, G. C., \& Calder, P. C. (2005). Conversion of alpha-linolenic acid to longer-chain polyunsaturated fatty acids in human adults. Reprod Nutr Dev, 45(5), 581-597.

Capuano, E., Grevink, R., Boerrigter-Eenling, R., \& van Ruth, S. M. (2015). Fatty acid and triglycerides profiling of retail organic, conventional and pasture milk: Implications for health and authenticity. International Dairy Journal, 42, 58-63.

Capuano, E., Rademaker, J., van den Bijgaart, H., \& van Ruth, S. M. (2014). Verification of fresh grass feeding, pasture grazing and organic farming by FTIR spectroscopy analysis of bovine milk. Food Research International, 60, 59-65.

Capuano, E., van der Veer, G., Boerrigter-Eenling, R., Elgersma, A., Rademaker, J., Sterian, A., \& van Ruth, S. M. (2014). Verification of fresh grass feeding, pasture grazing and organic farming by cows farm milk fatty acid profile. Food Chemistry, 164(0), 234-241.

Cirilli, M., Bellincontro, A., Urbani, S., Servili, M., Esposto, S., Mencarelli, F., \& Muleo, R. (2016). On-field monitoring of fruit ripening evolution and quality parameters in olive mutants using a portable NIR-AOTF device. Food Chemistry, 199, 96-104.

Collomb, M., Bisig, W., Bütikofer, U., Sieber, R., Bregy, M., \& Etter, L. (2008). Fatty acid composition of mountain milk from Switzerland: Comparison of organic and integrated farming systems. International Dairy Journal, 18(10-11), 976-982.

Coppa, M., Ferlay, A., Borreani, G., Revello-Chion, A., Tabacco, E., Tornambe, G., Pradel, P., \& Martin, B. (2015). Effect of phenological stage and proportion of fresh herbage in cow diets on milk fatty acid composition. Animal Feed Science and Technology, 208, 66-78

Coppa, M., Ferlay, A., Chassaing, C., Agabriel, C., Glasser, F., Chilliard, Y., Borreani, G., Barcarolo, R., Baars, T., Kusche, D., Harstad, O. M., Verbič, J., Golecký, J., \& Martin, B. (2013). Prediction of bulk milk fatty acid composition based on farming practices collected through on-farm surveys. Journal of Dairy Science, 96(7), 4197-4211. 
Delgadillo-Puga, C., Sanchez-Munoz, B., Nahed-Toral, J., Cuchillo-Hilario, M., Diaz-Martinez, M., Solis-Zabaleta, R., Reyes-Hernandez, A., \& Maria Castillo-Domiguez, R. (2014). Fatty acid content, health and risk indices, physicochemical composition, and somatic cell counts of milk from organic and conventional farming systems in tropical southeastern Mexico. Tropical Animal Health and Production, 46(5), 883-888.

El Bacha, T., Nunes, J., \& Torres, A. (2014). CLA intake from dairy fat in healthy young adults: beneficial effects on serum metabolome (643.6). The FASEB Journal, 28(1 Supplement), 643.646

Ellis, D. I., Muhamadali, H., Haughey, S. A., Elliott, C. T., \& Goodacre, R. (2015). Point-andshoot: rapid quantitative detection methods for on-site food fraud analysis-moving out of the laboratory and into the food supply chain. Analytical Methods, 7(22), 9401-9414.

Erich, S., Schill, S., Annweiler, E., Waiblinger, H.-U., Kuballa, T., Lachenmeier, D. W., \& Monakhova, Y. B. (2015). Combined chemometric analysis of 1 H NMR, 13 C NMR and stable isotope data to differentiate organic and conventional milk. Food Chemistry, 188, 1-7.

García Martín, J. F. (2015). Optical path length and wavelength selection using Vis/NIR spectroscopy for olive oil's free acidity determination. International Journal of Food Science \& Technology, 50(6), 1461-1467.

Haughey, S. A., Galvin-King, P., Malechaux, A., \& Elliott, C. T. (2015). The use of handheld near infrared reflectance spectroscopy for the proximate analysis of poultry feed and to detect melamine adulteration of soya bean meal. NIR news, 26(6), 4-7.

Hourant, P., Baeten, V., Morales, M. T., Meurens, M., \& Aparicio, R. (2000). Oil and fat classification by selected bands of near-infrared spectroscopy. Applied Spectroscopy, 54(8), 1168-1174.

Kuhn, M., \& Johnson, K. (2013). Applied predictive modeling (Vol. 26): Springer.

Larsen, M. K., Fretté, X. C., Kristensen, T., Eriksen, J., Søegaard, K., \& Nielsen, J. H. (2012). Fatty acid, tocopherol and carotenoid content in herbage and milk affected by sward composition and season of grazing. Journal of the Science of Food and Agriculture, 92(14), 2891-2898.

Li, L., Huang, C., \& Zhang, H. (2017). Micro/Nanoscale Optical Devices for Hyperspectral Imaging System. In Outlook and Challenges of Nano Devices, Sensors, and MEMS, (pp. 459-482): Springer.

Liu, N., Koot, A., Hettinga, K., de Jong, J., \& van Ruth, S. M. (2018). Portraying and tracing the impact of different production systems on the volatile organic compound composition of milk by PTR-(Quad)MS and PTR-(ToF)MS. Food Chemistry, 239, 201207.

Mabood, F., Jabeen, F., Ahmed, M., Hussain, J., Al Mashaykhi, S. A. A., Al Rubaiey, Z. M. A., Farooq, S., Boqué, R., Ali, L., Hussain, Z., Al-Harrasi, A., Khan, A. L., Naureen, Z., 
Idrees, M., \& Manzoor, S. (2017). Development of new NIR-spectroscopy method combined with multivariate analysis for detection of adulteration in camel milk with goat milk. Food Chemistry, 221, 746-750.

Malegori, C., Nascimento Marques, E. J., de Freitas, S. T., Pimentel, M. F., Pasquini, C., \& Casiraghi, E. (2017). Comparing the analytical performances of Micro-NIR and FTNIR spectrometers in the evaluation of acerola fruit quality, using PLS and SVM regression algorithms. Talanta, 165, 112-116.

McFadden, J. R., \& Huffman, W. E. (2017). Willingness-to-pay for natural, organic, and conventional foods: The effects of information and meaningful labels. Food Policy, 68, 214-232.

Nogueira, F. G., Felps, D., \& Gutierrez-Osuna, R. (2007). Development of an infrared absorption spectroscope based on linear variable filters. IEEE sensors journal, 7(8), 1183-1190.

Passing, H., \& Bablok, W. (1983). A new biometrical procedure for testing the equality of measurements from two different analytical methods. Application of linear regression procedures for method comparison studies in clinical chemistry, Part I. Clinical Chemistry and Laboratory Medicine, 21(11), 709-720.

Payling, L. M., Juniper, D. T., Drake, C., Rymer, C., \& Givens, D. I. (2015). Effect of milk type and processing on iodine concentration of organic and conventional winter milk at retail: implications for nutrition. Food Chemistry, 178, 327-330.

Pustjens, A. M., Boerrigter-Eenling, R., Koot, A. H., Rozijn, M., \& van Ruth, S. M. (2017). Characterization of Retail Conventional, Organic, and Grass Full-Fat Butters by Their Fat Contents, Free Fatty Acid Contents, and Triglyceride and Fatty Acid Profiling. Foods, 6(4), 26.

Renhorn, I. G., Bergström, D., Hedborg, J., Letalick, D., \& Möller, S. (2016). High spatial resolution hyperspectral camera based on a linear variable filter. Optical Engineering, 55(11), 114105-114105.

Shi, H., \& Yu, P. (2017). Comparison of grating-based near-infrared (NIR) and Fourier transform mid-infrared (ATR-FT/MIR) spectroscopy based on spectral preprocessing and wavelength selection for the determination of crude protein and moisture content in wheat. Food Control, 82(Supplement C), 57-65.

Soyeurt, H., Dardenne, P., Dehareng, F., Lognay, G., Veselko, D., Marlier, M., Bertozzi, C., Mayeres, P., \& Gengler, N. (2006). Estimating Fatty Acid Content in Cow Milk Using Mid-Infrared Spectrometry. Journal of Dairy Science, 89(9), 3690-3695.

van Ruth, S. M., Luning, P. A., Silvis, I. C. J., Yang, Y., \& Huisman, W. (2018). Differences in fraud vulnerability in various food supply chains and their tiers. Food Control, 84(Supplement C), 375-381. 
Westad, F., Schmidt, A., \& Kermit, M. (2008). Incorporating chemical band-assignment in near infrared spectroscopy regression models. Journal of near infrared spectroscopy, 16(3), 265-273.

Willer, H., \& Lernoud, J. (2017). The world of organic agriculture. Statistics and emerging trends 2017: Research Institute of Organic Agriculture FiBL and IFOAM Organics International. 


\section{Chapter 5}

\section{How organic is organic milk? Can we have a quick check?}

This chapter was published as: Saskia van Ruth \& Ningjing Liu, How organic is organic milk? Can we have a quick check? NIR news, Volume 30, 2019, 18-21. 


\begin{abstract}
The organic market is growing, and confidence is key. However, it is hard to distinguish an organic product from another regular product. In this article we examined a consumer NIRSVis device for its capabilities to distinguish organic retail milks from conventional milks. The study revealed differences between the two groups, allowing classification of samples, but these differences were not as distinct as those provided by other devices examined previously. Nevertheless, with some improvement of performance of this kind of devices and integration in smart phones, authentication of foods is within reach of citizens in the near future.
\end{abstract}

Keywords: Authentication; Handheld; Identity; Portable; Production system 


\subsection{How organic is organic?}

The term 'organic' refers broadly to agricultural practices that cover particular resource usage and considers animal welfare. Frameworks for organic practices have been established by several international organisations in order to formalise and certify 'organic' producers. In the EU, organic products have to meet specific EU regulations.

The organic food production and industry in Europe is a lucrative market. Retail sales amounted approximately 30 billion euro's in 2015. Considerable growth in consumption of organic products is seen, with Eastern European countries catching up. Germany is the leading market for organic products with a share of $11 \%$ of global organic sales (Statista, 2016).

Global milk production amounted ca. 800 billion litres in 2017 , ca. $1 \%$ of which was organic. Nevertheless, milk is an important product in the organic assortment. Its global annual value is estimated at 4 billion euro's currently. The organic farming costs are 1.3-1.6 times of those of conventional farms. This results in an added value for organic milk at the farm gate of $27-44 \%$ compared to conventional milk, and at retail level of an additional 9-53\%, depending on the country.

Although consumers have doubled their consumption in the last decade, this demand is outstripping supply. This results in rapid changes in organic market dynamics and marketing opportunities, which may be addressed in an unfair way by those that override their moral compass. To combat this kind of fraud and limit its impact, fraud mitigation measures are implemented. One of these measures is analytical testing of products, but this comes with a challenge for organic products, because there are fairly limited methods available. For organic milk authentication, carbon, and nitrogen isotopes have been suggested (Payling, Juniper, Drake, Rymer \& Givens, 2015), as well as fingerprints of the fat fraction of milk (Capuano, Grevink, Boerrigter-Eenling \& van Ruth, 2015). Although these methods work reasonably, they can only be conducted in a laboratory environment. Recently, Near-Infrared Spectroscopy (NIRS) -as a more rapid tool - has been evaluated in our laboratory for distinction of organic milk from conventional milk, both in the form of benchtop and handheld applications. For screening purposes, both seem feasible (Liu, Aya Parra, Pustjens, Hettinga, Mongondry, \& van Ruth, 2018). However, the handheld device tested was in a price range suiting inspectors or larger companies, but not consumers. How interesting would it be if organic products could be subjected to crowd analysis, with consumers testing their own meals? This article deals with such an application. We developed an application to distinguish organic milk from conventional milk in the Netherlands for a low-price NIRS-Vis device which runs with an app on a smart phone and uses cloud calculations, and we evaluated its performance. 


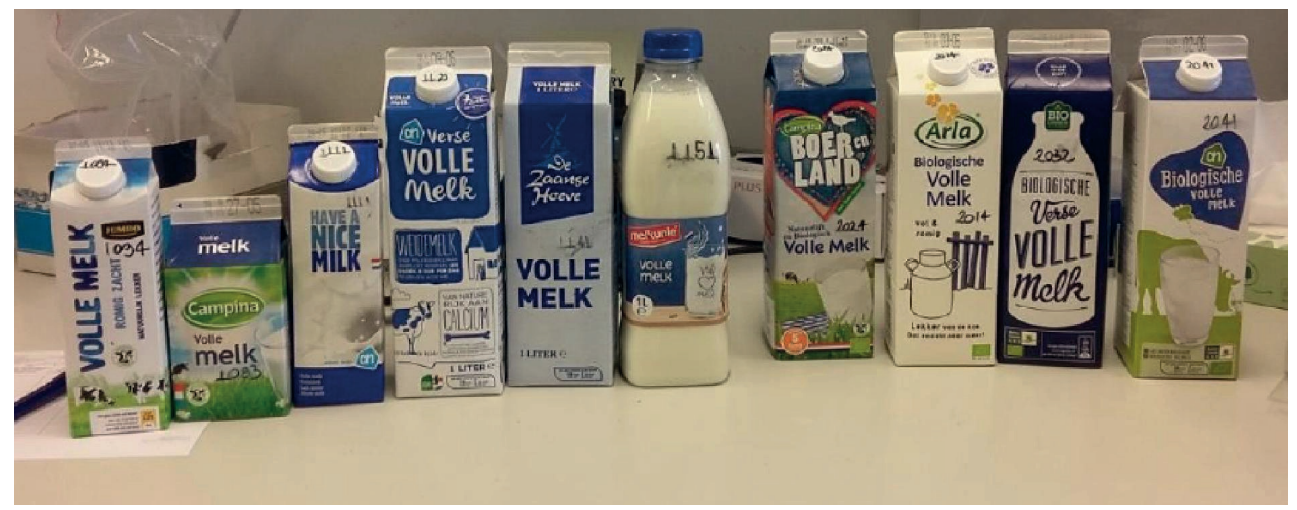

Fig. 5.1 Milk samples for analysis.

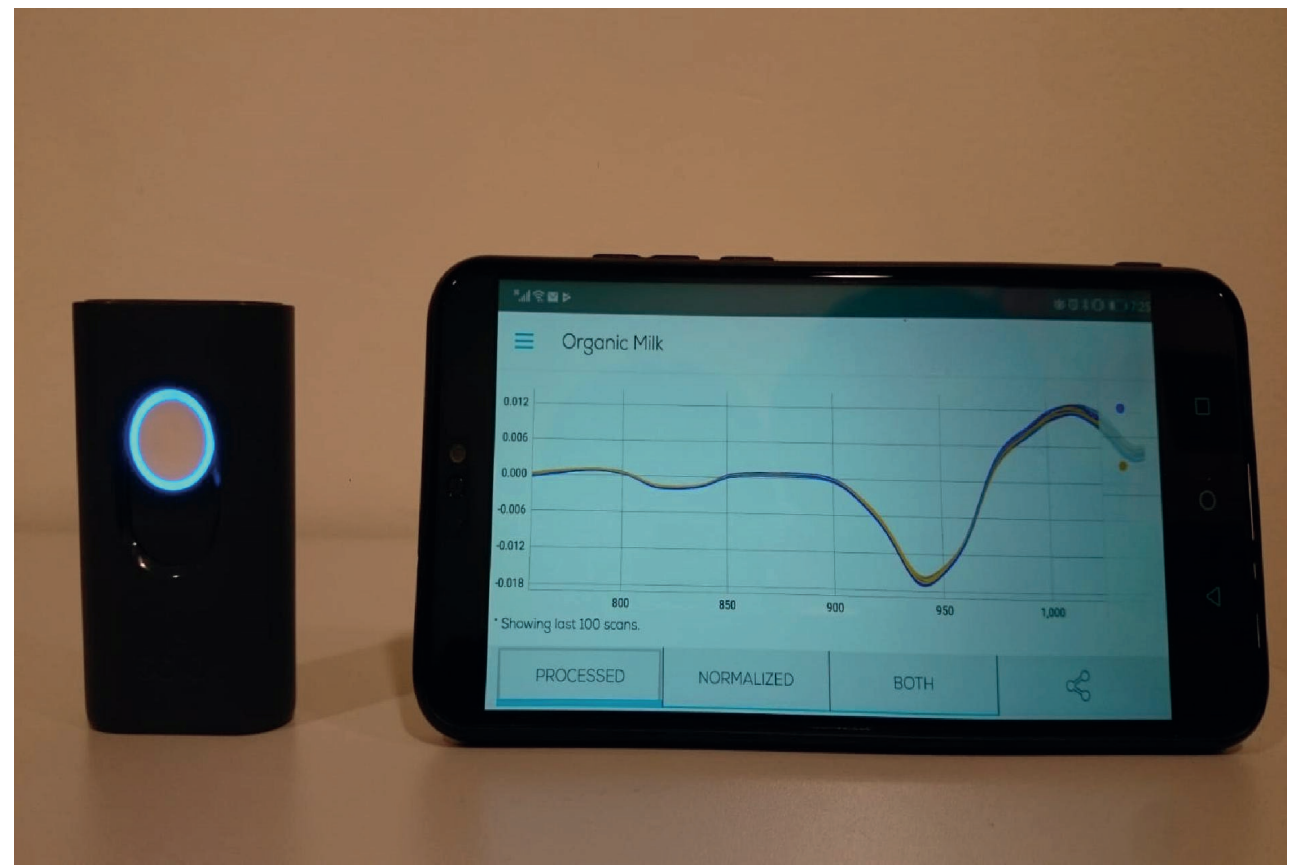

Fig. 5.2 The device.

\subsection{What did we do?}

Eighty-seven samples of full-fat, pasteurized retail milks were collected from grocery stores in the Netherlands during a period of eight weeks in the summer of 2016 (Fig. 5.1). The sample set included 37 organic retail milks and 50 conventional (non-organic) retail milks. All samples were analysed in triplicate with the mini Scio device (Consumer Physics, Israel; Fig. 5.2) along with its accessory for measurements in liquids allowing submergence of the device in a glass beaker of milk. Transmission data in the 740-1070 nm range were collected in 
triplicate, and calibration with the device white reference was conducted after analysis of each set of 3 samples ( 9 replicates). The device was operated with the company's developer app for smartphones and tablets available in google store and Apple store, and was synchronised with a smartphone via Bluetooth. Connection to the internet allowed storage of spectra in the developers portal or SCIO cloud. After completion of the analyses, all data were exported to Excel and triplicate readings were averaged for further data analysis. Classification statistics (Partial Least Difference Discriminant Analysis (PLS-DA)) were applied to the pre-processed data in order to examine the distinction of organic from conventional milk samples. The milks were also analysed for their fatty acid compositions by gas chromatography flame ionization detection. The correlation coefficients of the fatty acid proportions and the wavelength absorbances measured with the Scio device were calculated to explore underlying relationships.

\subsection{What did we find? Did it work?}

The organic and conventional milk samples were all analysed with the portable device. Mean spectra for organic and conventional milk groups are presented in Fig. 5.3.

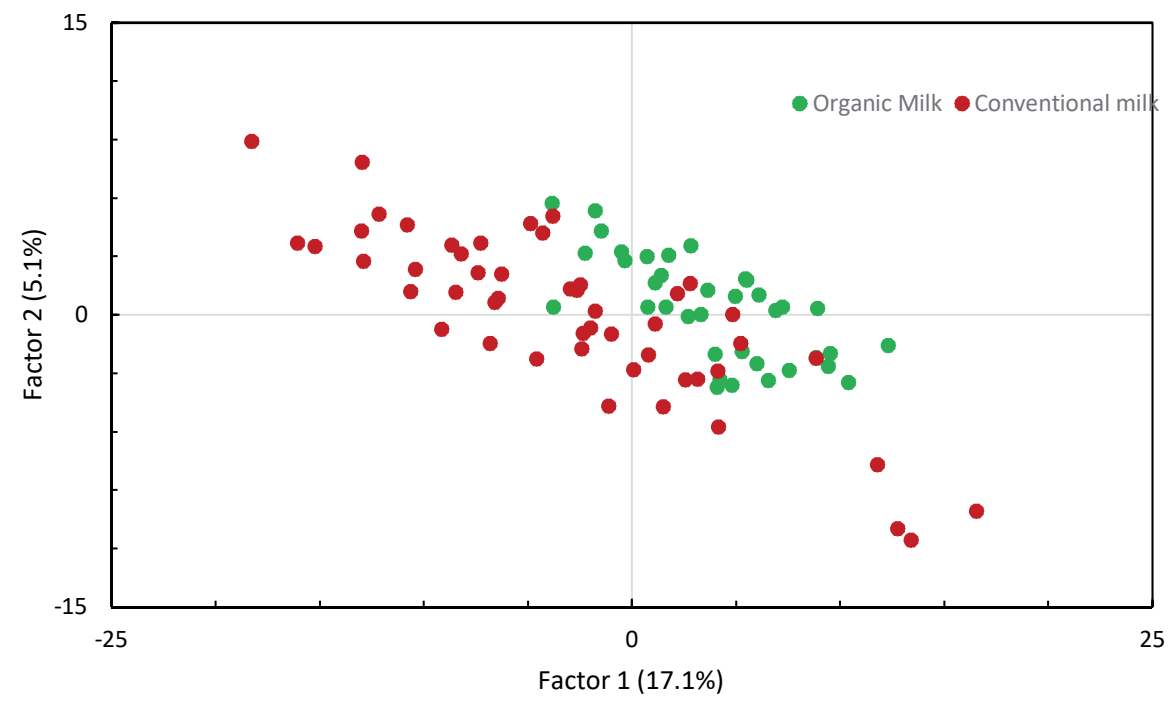

Fig. 5.4 Plot of the PLS-DA (classification statistics) on the spectral data of the organic and conventional milk samples acquired with the Scio device.

The mean spectra show differences between the two groups, which is promising. However, one has to consider the variation within the groups as well. Statistical comparison of the pre-processed data with classification statistics revealed reasonable separation of the two milk groups (Fig. 5.4). In cross validation, $89 \%$ of the organic milk samples and $80 \%$ of the 
conventional milk samples were assigned to the correct class. This result is reasonable considering that the previously examined handheld equipment for professionals or benchtop NIRS presented better performance (Liu, Aya Parra, Pustjens, Hettinga, Mongondry, \& van Ruth, 2018). The major advantage of this tiny device is, however, that it is in the price range of consumers and, therefore, available to many. This makes it even suitable for citizen science.

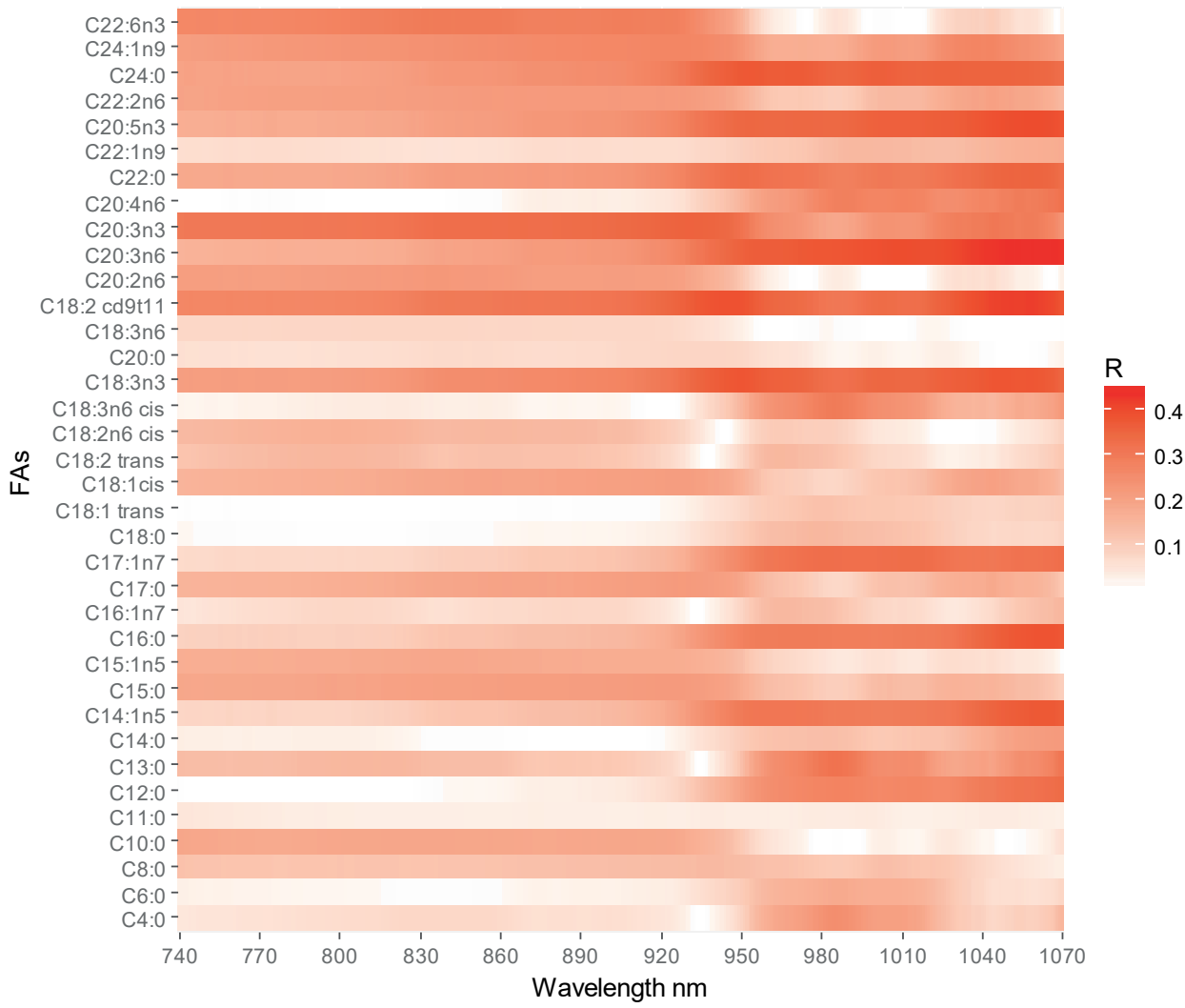

Fig. 5.5 Correlation plot of spectral data acquired with the Scio device and the fatty acid composition of the organic and conventional milk samples.

In order to examine the underlying reasons for the separation of the organic and conventional milk samples, the spectral data were correlated with the fatty acid composition data (Liu, Aya Parra, Pustjens, Hettinga, Mongondry, \& van Ruth, 2018). The results are shown in Fig. 5.5. C14:0 (myristic acid), C16:0 (palmitic acid), and C18:1 (oleic acid) together account for more than $50 \%$ of the total fatty acids. They all show higher concentrations in conventional milk than in organic milk. In the 740-920 nm wavelength range the correlation is relatively constant and the absorbance readings correlate primarily with larger fatty acids, including C18:1. In the 950-1040 $\mathrm{nm}$ range, other fatty acids start to play a role as well. These are mainly 
the shorter chain fatty acids. C16:0 also shows a distinct correlation with absorbance readings in this spectral range.

\subsection{Concluding remarks}

Our previous study showed that professional NIRS-based handheld devices present similar performance as a benchtop equivalent in terms of distinction of organic and conventional retail milks. We presented in this article the next step, the evaluation of a consumer device. It does show separation between organic and conventional milks, but the difference is not as distinct as with the other devices. On the other hand, it is a major step forward to be able to generate some relevant information on the production identity of milks with a consumer device.

\subsection{Outlook}

Developments with regard to miniaturization of devices which allows us to bring a device to the sample, instead of the other way around, are very interesting. There are sensitive, robust devices with a wide wavelength range which are aimed at the professional market, but also more simple devices are sold that are available in the citizen price range. Obviously, performance and price of devices in both groups differ. However, the fact that one can generate compositional information of a sample beyond a laboratory without years of training, is a major step forward. First attempts to integrate this kind of sensor technology in smart phones have been made, and when sensitivity and robustness increases over the next few years, citizen food authenticity science is around the corner. 


\subsection{References}

Capuano, E., Grevink, R., Boerrigter-Eenling, R., \& van Ruth, S. M. (2015). Fatty acid and triglycerides profiling of retail organic, conventional and pasture milk: Implications for health and authenticity. International Dairy Journal, 42, 58-63.

Liu, N., Aya Parra, H., Pustjens, A., Hettinga, K., Mongondry, P., \& van Ruth, S. M. (2018). Evaluation of portable near-infrared spectroscopy for organic milk authentication. Talanta, 184, 128-135.

Payling, L. M., Juniper, D. T., Drake, C., Rymer, C., \& Givens, D. I. (2015). Effect of milk type and processing on iodine concentration of organic and conventional winter milk at retail: implications for nutrition. Food Chemistry, 178, 327-330.

Statista (2016). https://www.statista.com/topics/3446/organic-food-market-in-europe/. 
CHAPTER 5 


\section{Chapter 6}

Portraying and tracing the impact of different production systems on the volatile organic compound composition of milk by PTR-(Quad)MS and PTR-(ToF)MS

This chapter was published as: Ningjing Liu, Alex Koot, Kasper Hettinga, Jacob de Jong, Saskia M. van Ruth, Portraying and tracing the impact of different production systems on the volatile organic compound composition of milk by PTR-(Quad)MS and PTR-(ToF)MS, Food Chemistry, Volume 239, 2018, 201-207. 


\begin{abstract}
The aim of this study was to discover the unique volatile compositional traits of retail milk from different production systems. Forty-four retail milk samples were analysed, including organic milk $(n=10)$, conventional milk $(n=14)$, and pasture milk $(n=20)$ from winter $(n=$ $22)$ and summer $(n=22)$. Proton transfer reaction quadrupole mass spectrometry (PTR(Quad)MS) was utilized to obtain the mass-resolved fingerprints (76 masses per sample) of volatile organic compounds (VOCs). Principal component analysis (PCA) and analysis of variance (ANOVA) were performed to evaluate the differences between the groups. The production systems were characterized by six masses, while season showed larger differences, with twenty-two masses discriminating between the milks. For 2 masses, a significant interaction of systems and seasons was observed. The chemical formulas of these VOC masses were tentatively identified by Proton Transfer Reaction Time-of-Flight Mass Spectrometric (PTR-(ToF)MS). These results illustrate that the type of feed is reflected in the VOC composition of milks.
\end{abstract}

Keywords: Organic milk; PTR-(Quad)MS; PTR-(ToF)MS; VOC 


\subsection{Introduction}

The concept of the organic production system has been widely recognized and implemented. In 2014, the global market of organic food and drinks had reached $\$ 80$ billion, while Europe took up $38 \%$. Among these, organic dairy is one of the most important organic sectors, since it has made up about 20 percent of total organic foods and drinks since 2013 (Willer \& Lernoud, 2015). To compensate for the strict rules and lower yield compared with milk from conventional dairy systems, organic milk always retailed at a higher price, i.e. approximately 30\% higher than conventional milk (Marian, Chrysochou, Krystallis, \& Thøgersen, 2014). Furthermore, since the EU milk quota regime came to an end in March 2015, more farmers look for added value of their products in order to differentiate from others. The combination of the higher price and the farmers looking for added value make organic milk vulnerable to fraud. In view of protection of consumers and providing a fair commercial environment, it is essential to assure the authenticity of organic milk.

Currently, in the Netherlands there is so-called 'pasture milk' on the market. It is produced by conventional dairy farms, but according to Dutch regulations, cows producing pasture milk should stay outdoors for at least 120 days per year, at least six hours a day. This is a management tool to encourage farmers to allow their cattle to roam outdoors, and dairy companies in the Netherlands pay extra price to farmers to support it. This kind of conventionalplus products draws the interest of consumers who are in favour of the idea of pasturing dairy cows. Since pasture milk is located between organic and conventional milk in terms of production management, it is relevant to consider pasture milk as well when comparing milk from the two systems.

Compared with farm milk, retail milk involves a series of processing steps, such as heating, standardization of fat content et al. During these steps, loss of VOCs that are present natively in different milks may occur. Furthermore, new VOCs may be formed as a consequence of heating, making it more difficult to find the native VOCs. These steps change the composition of milk and are likely to submerge some characteristics of organic milk. Furthermore, retail milk is a mixture of milks from different farms, which means characteristics will be more averaged and extremes levelled out. These aspects result in extra challenges for authentication. However, it is this mixture of milk that appears eventually on the shelfs of the supermarkets, so authentication should preferentially be possible at this level.

Up to now, most published studies on the authentication of organic milk focused on the differences of isotope ratio (IR) (Chung, Park, Yoon, Yang, \& Kim, 2014; Molkentin \& Giesemann, 2010) and fatty acids (FAs) composition (Capuano, Grevink, Boerrigter-Eenling, \& van Ruth, 2015; Capuano, van der Veer, Boerrigter-Eenling, Elgersma, Rademaker, Sterian, et al., 2014; Ferreiro, Gayoso, \& Rodríguez-Otero, 2015; Florence, Béal, Silva, Bogsan, Pilleggi, Gioielli, et al., 2012; Schwendel, Morel, Wester, Tavendale, Deadman, Fong, et al., 
2015 ) between organic and conventional milk. That is because in the organic sector, cows are fed higher percentages of grass (C3 plant), while in the conventional system maize (C4 plant) is the main feed. Due to the fact that $\delta^{13} \mathrm{C}$ of $\mathrm{C} 4$ plants (from $-9 \%$ o to $-20 \%$ ) is higher than the $\delta^{13} \mathrm{C}$ of C3 plants (from -21\%o to -35\%) (Badeck, Tcherkez, Nogués, Piel, \& Ghashghaie, 2005; Chung, Park, Yoon, Yang, \& Kim, 2014), organic milk generally possesses a lower $\delta^{13} \mathrm{C}$ value. With regard to the FAs composition, organic milk is richer in polyunsaturated FAs due to the higher proportion of fresh grass in the feed (Capuano, Grevink, Boerrigter-Eenling, \& van Ruth, 2015). The methods above consider the non-volatile compounds. Compared with non-volatile compounds, volatile organic compounds (VOCs) are present in milk at lower concentrations. VOCs may however reflect the composition of the feed as well as its interaction with the rumen metabolism (Villeneuve, Lebeuf, Gervais, Tremblay, Vuillemard, Fortin, et al., 2013). This aspect may be important for revelation of the unique traits of milk from the different production systems. Considering the global similarity of milk from different systems, a full profile of all VOCs is required to uncover small but consistent differences in characteristics.

Proton transfer reaction mass spectrometry (PTR-MS) is an advanced technique which allows measurement of the fingerprint of VOCs Compared with traditional gas chromatography mass spectrometry (GC-MS), PTR-MS can analyses the whole VOCs profile of the samples without sample preparation, while being sensitive and fast, and is therefore widely applied in many fields of food analysis, including dairy products analysis (Alothman, Lusk, Silcock, \& Bremer, 2017; Makhoul, Yener, Khomenko, Capozzi, Cappellin, Aprea, et al., 2016; Masi, Romani, Pandolfi, Heimler, \& Mancuso, 2015; Nenadis, Heenan, Tsimidou, \& Van Ruth, 2016; Schuhfried, del Pulgar, Bobba, Piro, Cappellin, Märk, et al., 2016). Proton transfer reaction quadrupole mass spectrometry (PTR-(Quad)MS), one of the most widely used instruments for VOC fingerprinting, can precisely describe a VOCs profile with a mass range from 1 to 512amu. Furthermore, PTR-MS equipped with a specially crafted high-end orthogonal acceleration reflection time of flight (ToF) shows a mass resolution of more than 6000 (up to $10,000 \mathrm{~m} / \mathrm{Dm})$, a considerably higher mass resolution than the more common PTR-(Quad)MS. This kind of higher resolution is helpful for the identification of the tentative chemical formula of the relevant masses. To our knowledge, no research has been reported on the differences in VOC composition of organic and conventional milks, especially with use of the rapid PTR(Quad)MS and PTR-(ToF)MS. The aim of this research was to portray and explain differences in VOC composition between organic and conventional milks by PTR-(Quad)MS and PTR(ToF)MS.

\subsection{Material and methods}

\subsubsection{Samples}

Forty-four full fat pasteurized retail milk samples from different brands were purchased in supermarkets in the Netherlands. They included 22 samples collected in the winter period (6 
organic, 8 conventional, 8 pasture milk) and 22 samples in summer ( 4 organic, 6 conventional, 12 pasture milk). All the samples were transferred from their original packages into $50 \mathrm{ml}$ plastic centrifuge tubes, and were stored at $-18^{\circ} \mathrm{C}$ until analysis. Samples were defrosted at $4{ }^{\circ} \mathrm{C}$ one day before analysis.

\subsubsection{PTR-(Quad)MS}

PTR-MS analyses the VOC profiles of samples by utilizing a tube to extract the headspace gas from the flask. After entering, volatile compounds react with $\mathrm{H}_{3} \mathrm{O}^{+}$generated from a hollow cathode ion source. Ionized volatile compounds are then analysed by a quadrupole mass spectrometer. The high sensitivity PTR-(Quad)MS (Ionicon GmbH, Innsbruck, Austria) was used to obtain the VOC profiles of the samples. In this study, $3 \mathrm{ml}$ milk sample was put into a $250 \mathrm{ml}$ flask (Duran, Germany) with a plastic screw cap (Duran, Germany). The samples were equilibrated in a $35^{\circ} \mathrm{C}$ water bath for $30 \mathrm{~min}$. The inlet flow was $58 \mathrm{ml}$ per min, and the temperature in the inlet tube and reaction chamber was $60^{\circ} \mathrm{C}$. The instrument was operated at a standard $\mathrm{E} / \mathrm{N}$ (ratio of electric field strength across the reaction chamber, E, to buffer gas number density, $\mathrm{N}$, within the chamber) of $105 \mathrm{Td}\left(1 \mathrm{Td}=10^{-17} \mathrm{~cm}^{2}\right.$ $\mathrm{V} \mathrm{mol}^{-1}$ ). The whole range of scanning for $\mathrm{H}^{3} \mathrm{O}^{+}$reacted VOCs was from 20-160 mass-charge ratio $(\mathrm{m} / \mathrm{z})$, with a $0.2 \mathrm{~s}$ per mass dwell time. Each sample analysis was followed by a blank consisting of an empty flask. Five complete cycles were run for each sample and blank, recording the middle three cycles for samples and the last three for blanks. The average of these three cycles was calculated as the value for each replicate, and blank signal was deducted from the sample signal. The measurement for each sample was replicated 3 times independently. Masses with average concentrations higher than $0.1 \mathrm{ppb}$ were considered for statistical analysis. The concentration of water cluster masses $\left(\mathrm{m} / \mathrm{z} 37\right.$ and 55) and $\mathrm{O}_{2}(\mathrm{~m} / \mathrm{z} 32)$ were removed from the spectral data (Galle, Koot, Soukoulis, Cappellin, Biasioli, Alewijn, et al., 2011).

\subsubsection{PTR-(ToF)MS}

Since the classes of compounds in each kind of milk are the same, four organic, four pasture, and four conventional milk samples, including winter and summer milks were selected from previous 44 samples and analysed by PTR-(ToF)MS (Ionicon GmbH, Innsbruck, Austria) to identify the chemical formula for each mass tentatively. These samples were selected according to the results of previous quadrupole analysis to representatively cover the variability. Regardless different concentrations, the types of compounds in different milks are consistent. The headspace measurement conditions were identical to those for the PTR-(Quad)MS analysis. The temperature of the inlet was $61^{\circ} \mathrm{C}$ and the reaction chamber was operated at a $1000 \mathrm{~V}$ drift voltage, a $3.80 \mathrm{mbar}$ drift pressure, and an E/N of $135 \mathrm{Td}$. Scanning was operated for 1 second, ranging from 17 to $507 \mathrm{~m} / \mathrm{z}$. A blank was measured before each sample. Each replicate was scanned 60 times, which resulted in an analysis time of $1 \mathrm{~min}$ per sample. Three replicates of each sample were analysed and the spectra subsequently averaged. 


\subsubsection{Statistical analysis}

The whole dataset was auto scaled to eliminate the effect of the different intensity range of each mass. Principal Component Analysis (PCA) was performed using Pirouette 4.5 (Infometrix, WA, USA) to evaluate the overall characteristics of the dataset. After that, oneway ANOVA was applied to the PTR-(Quad)MS data set to obtain the significant differences between milks derived from different systems and the differences between milk in summer and winter. In order to control family wise error of multiple comparison, Benjamini-Hochberg (BH) adjustment (Benjamini \& Hochberg, 1995) was applied. The P values from ANOVA were assessed and adjusted to maintain the false discovery rate (FDR) at 0.05 . Subsequently, Fisher's least significant difference (LSD) tests were applied to determine significant differences between the individual groups. Two-way ANOVA was applied to consider the production system and season factors simultaneously, and also examine their interactions. The variance component ratio (square sum of variance of certain factor/total square sum of variance) of each factor in the two-way ANOVA was calculated. The ratio value represents the contribution of each factor to the total observed variance. A higher ratio indicates a greater influence of a particular factor (Zhao, Guo, Wei, \& Zhang, 2012), in this study either the production system or the seasonal factor.

\subsection{Results and discussion}

Forty-four samples of organic, pasture, and conventional milks were collected and analysed by PTR-(Quad)MS. The mass range 27-160 amu was considered for data analysis after removing $\mathrm{m} / \mathrm{z} 32,37$, and 55. The average mass spectra are shown in Fig. 6.1. Masses $\mathrm{m} / \mathrm{z}$ 59 was the predominant mass for all samples, at least 6 times higher concentrations than the other masses. However, the concentrations of this mass do not present any significant differences, neither for the production systems nor for the seasons. Obviously the compounds' concentrations are influenced by other factors. Furthermore, retail samples are expected to show less variation due to the mixing of milks as well as through the industrial procedures, such as pasteurizing, fat standardizing and storing, which narrow the gap between different milk (Gandy, Schilling, Coggins, White, Yoon, \& Kamadia, 2008; Karatapanis, Badeka, Riganakos, Savvaidis, \& Kontominas, 2006). 

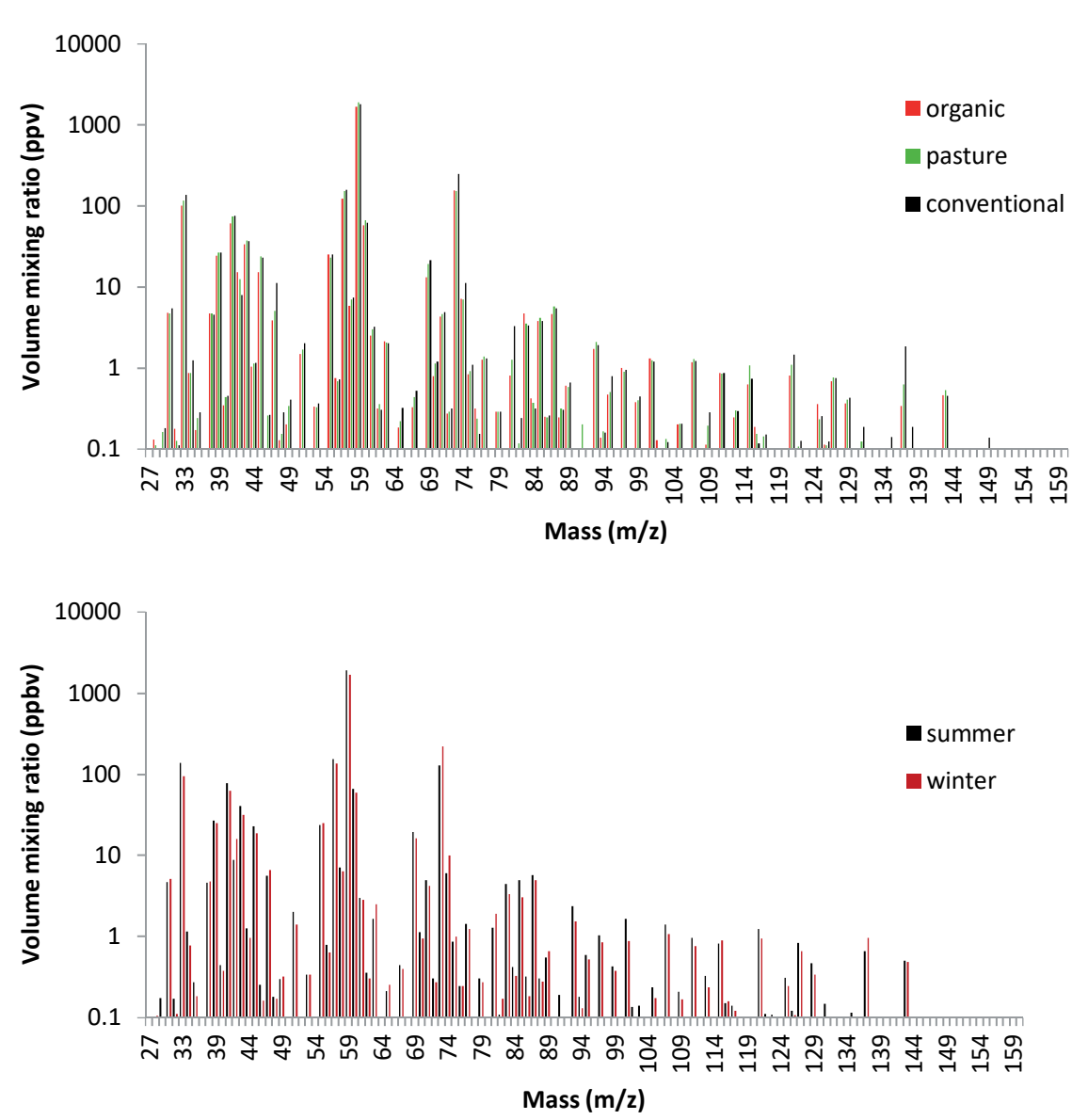

Fig. 6.1 PTR-(Quad)MS spectra: Average VOC spectra of organic, pasture, and conventional milks (upper); Average spectra of all winter and summer milks (lower).

Statistical analysis on the full profile was carried out to search for the small but consistent differences between the milks of the three production systems. All spectral data were subjected to PCA. A PCA scores plot is presented in Fig. 6.2, which shows the grouping trend of the organic samples versus the others. The first three PCs explain 39\% of total variance. The relatively low explained variance reflects the multidirectional differences between organic and conventional milk, which cannot be illustrated completely by one or two components. Random variance within and among the groups also contributes to the relatively low variance explanation. In the PCA scores plot, conventional samples are distributed over the left part while the organic samples distribute in the right part, except for one sample. Pasture samples are mixed with both organic and conventional milk and are located relatively close to the demarcation line between organic and conventional milks. Season is shown to have a large influence on the VOC composition as well. 


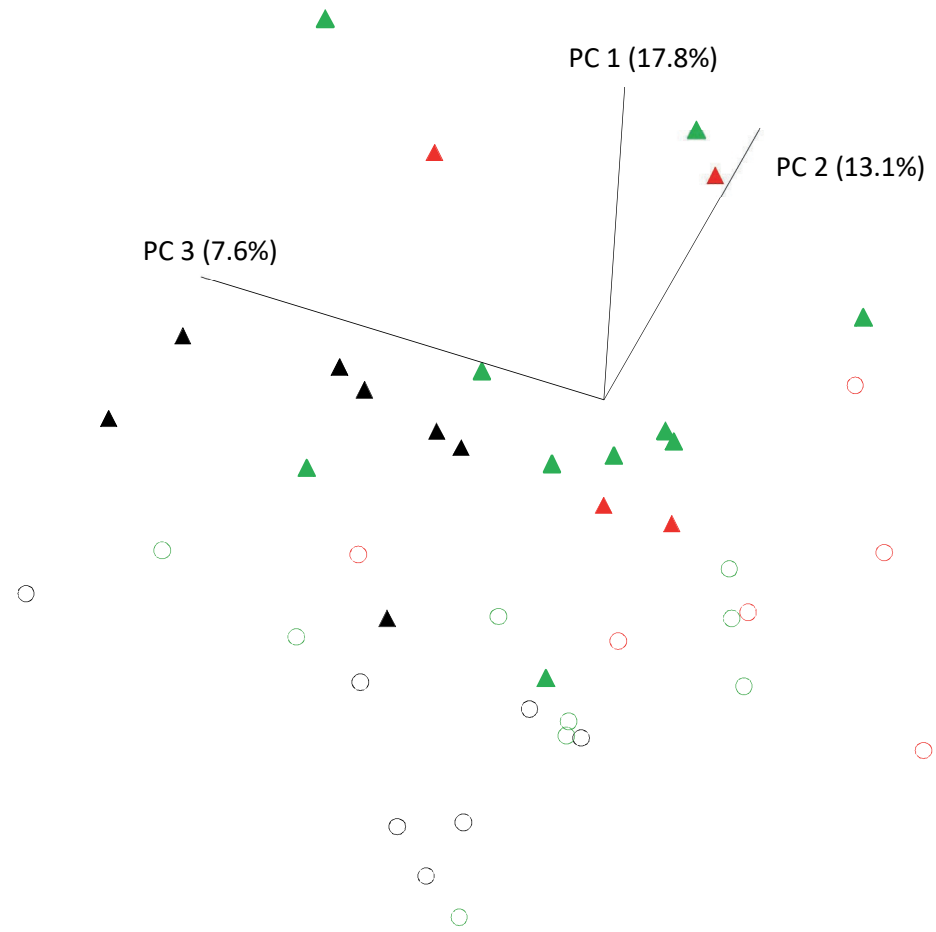

Fig. 6.2 Scores plot of first three dimensions of PCA on the mass spectral data of VOCs of organic (red), pasture (green), and conventional (black) milk in winter (open circles) and summer (solid triangle).

In the PCA scores plot, the winter and summer samples are mainly located at the lower and upper side of the plot, respectively. Combining the information on the seasons and production systems, it is interesting to find that pasture milk in summer is close to organic milk, while pasture milk in winter is more similar to conventional milk. This may be due to the requirements for pasture milk, which dictates a particular quantum of grazing. Pasture milk farmers will have cows outside during summer when the grass is abundant and temperature outside is acceptable, which explains the similarity of summer pasture milk and organic milk VOC composition. After spending the minimum time on pasture, a part of farmers would manage their cows in a more conventional way to increase yields (Cederberg \& Mattsson, 2000). If cows are not grazing at all in winter, this milk can still be sold as pasture milk, as long as the cows fulfil the grazing requirements over the whole year. Since the grassland of pasture milk is also cultivated in conventional ways, the similarity of summer pasture milk with organic milk indicates that the characteristics of VOCs in organic milk are more related to the specific feed type (fresh grass) instead of the organic management of the grass. In winter time, cows in the 'pasture milk system' will be managed equally to those in the conventional systems, which explains the similarity with the conventional milk in winter time. In order to search for the 
relevant masses contributing to the differences between groups, ANOVA was performed for each mass, taking the production systems and the seasons into account.

\subsubsection{Effect of the production system}

Significant differences $(\mathrm{BH}$ adjusted $\mathrm{P}<0.05)$ between different production systems were observed for six masses (Table 6.1). Generally, organic milks showed higher abundances of these discriminating VOCs than milks from the other production systems. It is important to note that these specific masses are present at relatively low concentrations. Three of the significantly different masses were present at volume mixing ratios lower than $1 \mathrm{ppbv}$, whereas mass $\mathrm{m} / \mathrm{z}$ 69, was the most abundant discriminating mass with a level of $18 \mathrm{ppbv}$ (mean value of all the samples). This is still relatively low when compared with the predominant mass $\mathrm{m} / \mathrm{z}$ 59, for which a volume mixing ratio of $1797 \mathrm{ppbv}$ was observed. It illustrates a fact that the major volatile compounds reflect the principal profile of the milk, while some less predominant compounds show the traits of milk derived from different systems. In order to examine the significant differences between the three different systems, post hoc Fisher's LSD tests were subsequently applied. All these six masses revealed significant differences in concentration between organic and conventional milk. In contrast, three masses showed significantly different concentrations between conventional milk and pasture milk, whereas four masses were different between organic and pasture milk. Therefore, in general, pasture milk shows more similarity to conventional milk. These results are in line with those reported by Capuano et al. (2015), who studied the FA and triglyceride (TAG) profile of organic milk, conventional milk, and pasture milk. The FA and TAG profiles of pasture milk and conventional milk were also highly similar. They concluded that this phenomenon was observed for the following reasons: (1) the flexible rules for pasture milk are not enough to generate differences; (2) the mixture of milks into retail milk can conceal the small differences between these two kinds of milk, since rules only specify the total outdoors time instead of the exact period, and the mixture in retail milk could possibly consist of indoors milk and outdoors milk at the same time; (3) some conventional cows could also graze outside or be fed with fresh grass.

Table 6.1 Masses showing significant differences in abundance for organic, pasture, and conventional milks analysed by PTR-(Quad)MS: mean volume mixing ratios (ppbv), standard deviation, and P value (ANOVA)

\begin{tabular}{lllll}
\hline Mass (m/z) & Organic $(\mathbf{n}=\mathbf{1 0})$ & Pasture $(\mathbf{n}=\mathbf{2 0})$ & $\begin{array}{l}\text { Conventional } \\
(\mathbf{n}=\mathbf{1 4})\end{array}$ & P value $^{\mathrm{b}}$ \\
\hline 47 & $11 \pm 9^{\mathrm{b}}$ & $5 \pm 3^{\mathrm{a}}$ & $4 \pm 2^{\mathrm{a}}$ & 0.03 \\
48 & $0.3 \pm 0.2^{\mathrm{b}}$ & $0.2 \pm 0.1^{\mathrm{a}}$ & $0.1 \pm 0.1^{\mathrm{a}}$ & 0.03 \\
67 & $0.5 \pm 0.1^{\mathrm{b}}$ & $0.4 \pm 0.1^{\mathrm{a}}$ & $0.3 \pm 0.1^{\mathrm{a}}$ & 0.03 \\
69 & $21 \pm 6^{\mathrm{b}}$ & $19 \pm 6^{\mathrm{a}}$ & $13 \pm 3^{\mathrm{a}}$ & 0.03 \\
70 & $1.2 \pm 0.3^{\mathrm{b}}$ & $1.1 \pm 0.4^{\mathrm{b}}$ & $0.8 \pm 0.2^{\mathrm{a}}$ & $<0.01$
\end{tabular}




\begin{tabular}{|c|c|c|c|c|}
\hline Mass $(\mathbf{m} / \mathbf{z})$ & Organic $(n=10)$ & Pasture $(n=20)$ & $\begin{array}{l}\text { Conventional } \\
(n=14)\end{array}$ & P value ${ }^{b}$ \\
\hline 109 & $0.3 \pm 0.1^{\mathrm{c}}$ & $0.2 \pm 0.1^{\mathrm{b}}$ & $0.1 \pm 0.1^{\mathrm{a}}$ & $<0.01$ \\
\hline
\end{tabular}

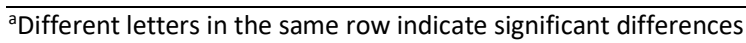

(Fisher's LSD test, $\mathrm{P}<0.05)$; ${ }^{\mathrm{b}}$ Adjusted according to Benjamini-Hochberg (BH).

To identify the tentative chemical formula of the characteristic ions, PTR-(ToF)MS analysis was carried out. Thanks to the higher resolution, the exact mass value could be measured after which the compounds were further tentatively identified with the help of related references (Table 6.3). Masses m/z 67, 69, and 70 showed significantly higher concentrations in organic milk. From the PTR-(ToF)MS it appears that these masses represent terpenes or fragments of terpenes. Terpenes are a class of compounds which are specifically present in plants (Tornambé, Cornu, Pradel, Kondjoyan, Carnat, Petit, et al., 2006) and can remain stable during metabolism in the cow (Ueda, Asakuma, Miyaji, \& Akiyama, 2015). The relationship between the concentration of terpenes and milk production systems has been reported before by Abilleira et al. (2011). Combined with the results in our research, these compounds have the potential to be characteristic traits or markers for organic milk, or at least for outdoor grazing.

Based on the results above, it can be concluded that, with the help of PTR-(TOF)MS, the characteristic and discriminating VOCs for the production systems have been elucidated and tentatively identified.

\subsubsection{Effect of the seasons}

Twenty-two masses showed significant differences between the summer and winter milks (Table 6.2 and 3), i.e. considerably more than the number of masses showing differences between the production systems (six masses). This is probably related to the greater differences in feeding strategies between winter and summer. During winter, there are higher proportions of silage, hay, and grain fed, while in summer, more fresh grass is available for feeding (Biolatto, Grigioni, Irurueta, Sancho, Taverna, \& Pensel, 2007). Actually most of the cows are fed with silage in winter in the Netherlands because of the shortage of fresh grass. In winter time, the main difference between organic and conventional/pasture cow feed is that the latter will contain more concentrates and the silage will comprise a higher proportion of maize. This leads to some differences, but they are smaller than the impact of the difference between fresh grass (summer feed) and silage (winter feed) on the VOC composition of the milk.

Table 6.2 Masses showing significant differences in abundance between winter and summer milks analysed by PTR-(Quad)MS: mean volume mixing ratios (ppbv), standard deviation, and P value (ANOVA).

\begin{tabular}{llll}
\hline $\begin{array}{l}\text { Mass } \\
(\mathbf{m} / \mathbf{z})\end{array}$ & Summer $(\mathbf{n}=\mathbf{2 2})$ & Winter $(\mathbf{n}=\mathbf{2 2})$ & P value $^{\mathbf{a}}$ \\
\hline 33 & $130 \pm 50$ & $90 \pm 30$ & $<0.01$
\end{tabular}




\begin{tabular}{|c|c|c|c|}
\hline $\begin{array}{l}\text { Mass } \\
(\mathrm{m} / \mathrm{z})\end{array}$ & Summer $(n=22)$ & Winter $(n=22)$ & P value $^{\mathbf{a}}$ \\
\hline 35 & $0.3 \pm 0.1$ & $0.2 \pm 0.1$ & 0.02 \\
\hline 42 & $9 \pm 4$ & $16 \pm 6$ & $<0.01$ \\
\hline 43 & $40 \pm 7$ & $31 \pm 6$ & $<0.01$ \\
\hline 44 & $1.2 \pm 0.3$ & $1.0 \pm 0.2$ & $<0.01$ \\
\hline 51 & $2.0 \pm 0.6$ & $1.4 \pm 0.5$ & $<0.01$ \\
\hline 63 & $2 \pm 1$ & $2 \pm 1$ & 0.05 \\
\hline 71 & $5 \pm 1$ & $4 \pm 1$ & 0.02 \\
\hline 73 & $130 \pm 60$ & $220 \pm 110$ & 0.01 \\
\hline 74 & $6 \pm 3$ & $10 \pm 5$ & 0.01 \\
\hline 84 & $0.4 \pm 0.1$ & $0.3 \pm 0.1$ & 0.05 \\
\hline 85 & $4.9 \pm 0.7$ & $3.0 \pm 0.4$ & $<0.01$ \\
\hline 86 & $0.3 \pm 0.1$ & $0.2 \pm 0.0$ & $<0.01$ \\
\hline 87 & $6 \pm 1$ & $5 \pm 1$ & 0.05 \\
\hline 93 & $2.3 \pm 0.5$ & $1.5 \pm 0.4$ & $<0.01$ \\
\hline 94 & $0.2 \pm 0.1$ & $0.1 \pm 0.1$ & 0.02 \\
\hline 101 & $1.6 \pm 0.5$ & $0.9 \pm 0.5$ & $<0.01$ \\
\hline 107 & $1.4 \pm 0.3$ & $1.1 \pm 0.2$ & $<0.01$ \\
\hline 111 & $1.0 \pm 0.2$ & $0.8 \pm 0.2$ & $<0.01$ \\
\hline 113 & $0.3 \pm 0.1$ & $0.2 \pm 0.1$ & $<0.01$ \\
\hline 127 & $0.8 \pm 0.1$ & $0.7 \pm 0.1$ & $<0.01$ \\
\hline 129 & $0.5 \pm 0.1$ & $0.3 \pm 0.1$ & $<0.01$ \\
\hline
\end{tabular}

Among the 22 significant differing masses, there are 14 masses with concentrations higher than $1 \mathrm{ppbv}$, tentatively identified as 10 different compounds (Table 6.3), excluding fragments and isotopologues. Data on cow's milk are not always available, therefore, also data on other dairy products are evaluated. The compound 2-butanone (mass $\mathrm{m} / \mathrm{z} 73$ ) is the major compound showing significant differences between summer and winter milks. Since the concentration of 2-butanone is higher in milk derived from silage and lower in the milk derived from fresh grass, it reflects the higher usage of silage during winter (Croissant, Washburn, Dean, \& Drake, 2007). Rios et al. (2008) reported that toluene (mass m/z 93) and benzaldehyde (mass $\mathrm{m} / \mathrm{z} 107$ ) could be generated by the degradation of carotenoids. In our research, the higher concentrations of toluene and benzaldehyde could be explained by the larger amount of carotenoids in fresh grass during summer time, with similar results by Sivadier et al. (2010). According to previous researches, the concentration of hexanone (mass $\mathrm{m} / \mathrm{z} 101$ ) in cheese decreased when silage was part of the ruminant diet (M Bergamaschi, Aprea, Betta, Biasioli, Cipolat-Gotet, Cecchinato, et al., 2015; Muñoz, Ortigosa, Torre, \& Izco, 2003). Butenal (mass $\mathrm{m} / \mathrm{z} 71$ ) is also evidenced as diet tracer of pasture fed lambs (Sivadier, Ratel, Bouvier, \& Engel, 2008; Sivadier, Ratel, \& Engel, 2010), but Vasta et al. (2006) reported these compounds could be derived from the oxidation of lipid, which could also have happened during retail milk processing and storage. In this case, given the higher concentrations of butenal in summer milk 
in the study, no conclusion can be drawn for the relationship between these compounds and summer diet. There are two additional compounds which show significantly higher concentrations in winter milk acetonitrile $(\mathrm{m} / \mathrm{z} 42)$ and dimethyl-sulfide $(\mathrm{m} / \mathrm{z} 63)$. Since the winter diet comprises higher contents of concentrates (Heck, van Valenberg, Dijkstra, \& van Hooijdonk, 2009), the concentrations of crude protein, casein, true protein and whey protein in winter milk are significantly higher than the concentrations in summer milk (Kř́žová, Hanuš, Roubal, Kučera, \& Hadrová, 2013). The higher protein content in the diet may result in elevated concentrations of compounds derived from protein degradation (Forss, 1979), such as the compounds mentioned, i.e. acetonitrile and dimethyl sulfide (Muñoz, Ortigosa, Torre, \& Izco, 2003).

Table 6.3 Tentative identification of VOCs by PTR-(TOF)MS.

\begin{tabular}{|c|c|c|c|c|}
\hline $\begin{array}{l}\text { Mass measured in } \\
\text { PTR-(Quad)MS } \\
(\mathbf{m} / \mathbf{z})\end{array}$ & $\begin{array}{l}\text { Mass } \\
\text { measured in } \\
\text { PTR- } \\
(\text { ToF)MS }\end{array}$ & $\begin{array}{l}\text { Protonated } \\
\text { chemical } \\
\text { formula }\end{array}$ & $\begin{array}{l}\text { Tentative } \\
\text { identification }\end{array}$ & Reference $^{\mathrm{a}}$ \\
\hline 33 & 33.034 & $\mathrm{CH}_{4} \mathrm{OH}+$ & Methanol & 1 \\
\hline 35 & 35.037 & $\mathrm{CH}_{4}{ }^{18} \mathrm{OH}+$ & Methanol & 1 \\
\hline 42 & 42.034 & $\mathrm{C}_{2} \mathrm{H}_{4} \mathrm{~N}+$ & Acetonitrile & 1 \\
\hline \multirow[t]{2}{*}{43} & 43.054 & $\mathrm{C}_{3} \mathrm{H}_{6} \mathrm{H}+$ & Alkyl fragment & 1,2 \\
\hline & 43.017 & $\mathrm{C}_{2} \mathrm{H}_{2} \mathrm{OH}+$ & Ester fragment & 2 \\
\hline 44 & 44.021 & ${ }^{13} \mathrm{CCH}_{2} \mathrm{OH}+$ & Ester fragment & 2 \\
\hline \multirow[t]{2}{*}{47} & 47.012 & $\mathrm{CH}_{2} \mathrm{O}_{2} \mathrm{H}+$ & Formic acid & 2 \\
\hline & 47.049 & $\mathrm{C}_{2} \mathrm{H}_{6} \mathrm{OH}+$ & Ethanol & 3 \\
\hline 48 & 48.052 & ${ }^{13} \mathrm{CCH}_{6} \mathrm{OH}+$ & Ethanol & 3 \\
\hline 51 & 51.044 & $\mathrm{NI}^{\mathrm{b}}$ & & - \\
\hline 63 & 63.025 & $\mathrm{C}_{2} \mathrm{H}_{6} \mathrm{SH}+$ & Dimethyl-sulfide & 1,4 \\
\hline 65 & 65.060 & $\mathrm{C}_{2} \mathrm{H}_{8} \mathrm{O}_{2} \mathrm{H}+$ & Hydrated ethanol & 5 \\
\hline 67 & 67.054 & $\mathrm{C}_{5} \mathrm{H}_{6} \mathrm{H}+$ & $\begin{array}{l}\text { Pentenal } \\
\text { fragment(terpene) }\end{array}$ & 2 \\
\hline 69 & 69.070 & $\mathrm{C}_{5} \mathrm{H}_{8} \mathrm{H}+$ & $\begin{array}{l}\text { 2-Methyl-1,3- } \\
\text { butadiene(isoprene) }\end{array}$ & 1 \\
\hline 70 & 70.073 & ${ }^{13} \mathrm{CC}_{4} \mathrm{H}_{8} \mathrm{H}+$ & Isoprene & 1 \\
\hline \multirow[t]{2}{*}{71} & 71.049 & $\mathrm{C}_{4} \mathrm{H}_{6} \mathrm{OH}+$ & Butenal & $2,3,6$ \\
\hline & 71.085 & $\mathrm{C}_{5} \mathrm{H}_{10} \mathrm{H}+$ & 3-Methyl-1-butanol & 3 \\
\hline 73 & 73.065 & $\mathrm{C}_{4} \mathrm{H}_{8} \mathrm{OH}+$ & 2-Butanone & $3,4,6,7$ \\
\hline 74 & 74.067 & ${ }^{13} \mathrm{CC}_{3} \mathrm{H}_{8} \mathrm{OH}+$ & 2-Butanone & $3,4,6,7$ \\
\hline 84 & 84.088 & ${ }^{13} \mathrm{CC}_{5} \mathrm{H}_{10} \mathrm{H}+$ & Hexanal fragment & 4,7 \\
\hline 85 & 85.100 & $\mathrm{C}_{6} \mathrm{H}_{12} \mathrm{H}+$ & Hexene & 7 \\
\hline 86 & 86.104 & ${ }^{13} \mathrm{CC}_{5} \mathrm{H}_{12} \mathrm{H}+$ & Hexene & 7 \\
\hline 87 & 87.079 & $\mathrm{C}_{5} \mathrm{H}_{10} \mathrm{OH}+$ & Pentanone/pentanal & 4,7 \\
\hline 93 & 93.070 & $\mathrm{C}_{7} \mathrm{H}_{8} \mathrm{H}+$ & Toluene & 7 \\
\hline 94 & 94.073 & ${ }^{13} \mathrm{CC}_{6} \mathrm{H}_{8} \mathrm{H}+$ & Toluene & 7 \\
\hline
\end{tabular}




\begin{tabular}{lllll}
\hline $\begin{array}{l}\text { Mass measured in } \\
\text { PTR-(Quad)MS } \\
(\mathbf{m} / \mathbf{z})\end{array}$ & $\begin{array}{l}\text { Mass } \\
\text { measured in } \\
\text { PTR- } \\
\text { (ToF)MS }\end{array}$ & $\begin{array}{l}\text { Protonated } \\
\text { chemical } \\
\text { formula }\end{array}$ & $\begin{array}{l}\text { Tentative } \\
\text { identification }\end{array}$ & Reference $^{\mathbf{a}^{2}}$ \\
\hline 101 & 101.094 & $\mathrm{C}_{6} \mathrm{H}_{12} \mathrm{OH}+$ & Hexanal/hexanone & $3,4,5,7,9$ \\
107 & 107.050 & $\mathrm{C}_{7} \mathrm{H}_{6} \mathrm{OH}+$ & Benzaldehyde & 4 \\
109 & 109.071 & $\mathrm{C}_{8} \mathrm{H}_{12} \mathrm{H}+$ & $2,6-$-Dimethyl pyrazine & 8 \\
111 & 111.081 & $\mathrm{C}_{7} \mathrm{H}_{10} \mathrm{OH}+$ & $2,4-$ Heptadienal & 4 \\
113 & 113.095 & $\mathrm{C}_{7} \mathrm{H}_{12} \mathrm{OH}+$ & Heptenal & 4,7 \\
127 & 127.112 & $\mathrm{C}_{8} \mathrm{H}_{14} \mathrm{OH}+$ & 1-Octen-3-one & 4 \\
129 & 129.127 & $\mathrm{C}_{8} \mathrm{H}_{16} \mathrm{OH}+$ & Octanone & 6 \\
\hline
\end{tabular}

a: 1. Galle, et al. (2011); 2. Buhr, et al. (2002); 3. Valero, et al. (2001); 4. Villeneuve, et al. (2013); 5. Veronika, et al. (2014); 6. Routray, et al. (2011); 7. Pereda , et al. (2008); 8. Bergamaschi, et al. (2015);

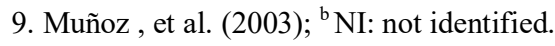

\subsubsection{Interactions of production systems and seasons}

Two-way ANOVA was performed to investigate the interaction of systems and seasons. According to the results of two-way ANOVA, the concentrations of four masses were significantly influenced by both systems and seasons, i.e. methanol $(\mathrm{m} / \mathrm{z} 35)$, acetonitrile $(\mathrm{m} / \mathrm{z}$ $42)$, isoprene $(\mathrm{m} / \mathrm{z} 70)$, and pentanone/pentanal ( $\mathrm{m} / \mathrm{z} 87)$. The contribution of the production system and seasonal factors were subsequently evaluated. System percentages of the total square sum of variance of these four masses amounted 45, 39, 68, and 47\% respectively. Similarly for the seasonal effect, percentages were $54,60,21$, and $40 \%$ respectively. The contribution of the production system was more pronounced for isoprene $(\mathrm{m} / \mathrm{z} 70)$.

The masses above showed no significant interactions of the two factors though. Among all 132 masses, two masses presented significant production system x season interactions. Formic acid/ethanol (m/z 47) and hydrated ethanol (m/z 65) showed significant different effects of the systems during summer and winter. Their abundances are shown in Fig. 6.3. During winter, the measured concentrations were significantly higher for organic milk, whereas in summer no significant influence of the systems was observed $(\mathrm{P}>0.05)$. This is probably due to different feeding strategies in summer and winter seasons. In summer more similarities in grass feeding may exist, either by grazing or supplied in the farm. In winter time in conventional farms the concentrate proportion may be higher and the grass proportion in silage may be lower than in organic farms resulting in these consistent differences in VOC concentrations. The two 
masses appear to be unique markers for organic milk in winter time, but are not useful for substantiation or discrimination of organic summer milks.

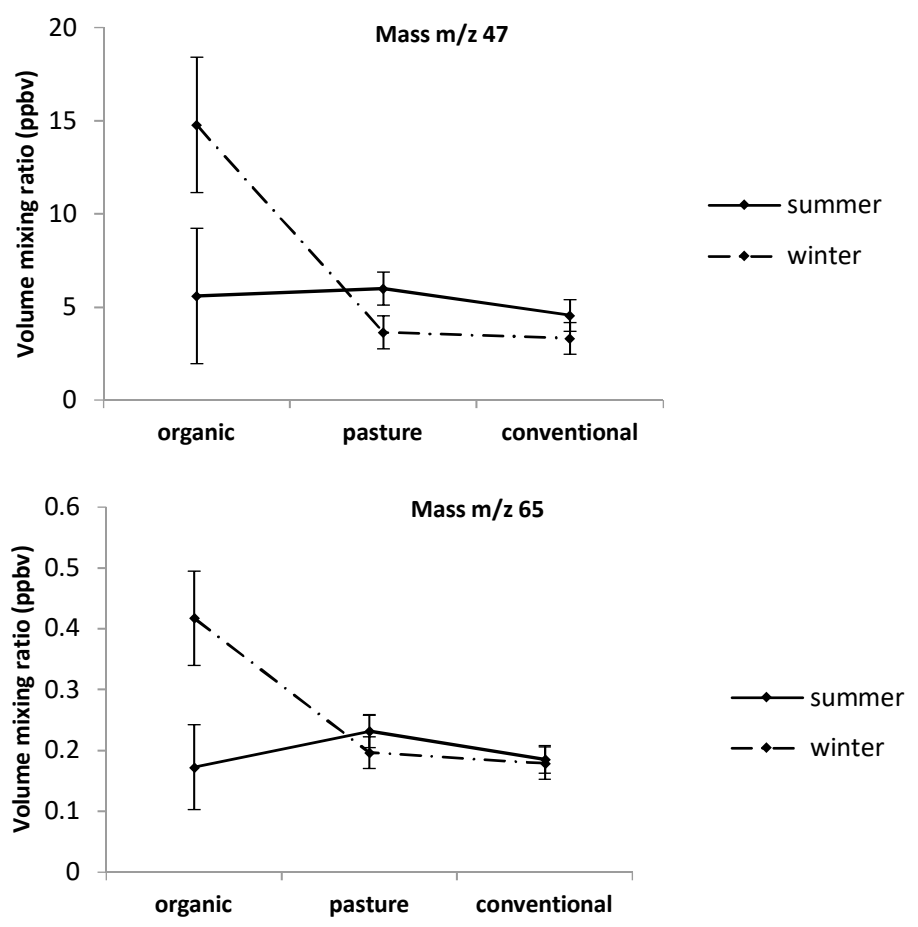

Fig. 6.3 Masses identified in PTR-(Quad)MS analysis showing significant interactions of the production system factor and the seasonal factor.

\subsection{Conclusion}

The study has demonstrated the different volatile profiles of organic, pasture, and conventional milk during winter and summer. Terpenes and their fragments appear important markers for organic milks. Organic and conventional milks show substantial differences in VOC composition, whereas pasture milks show an intermediate pattern, being more similar to organic in summer time and more similar to conventional in winter time, reflecting their seasonally changing feed strategy. Organic milks differ more distinct in VOC composition from conventional and pasture milks in winter time due to the more distinct feeding regimes. The VOC markers are useful for future development of methods for the authentication of organic milks.

\subsection{Acknowledgment}

Authors wish to acknowledge support by the China Scholarship Council (CSC). 


\subsection{References}

Abilleira, E., Virto, M., Najera, A. I., Albisu, M., Perez-Elortondo, F. J., de Gordoa, J. R., Renobales, M., \& Barron, L. J. R. (2011). Effects of seasonal changes in feeding management under part-time grazing on terpene concentrations of ewes' milk. Journal of Dairy Research, 78(2), 129-135.

Alothman, M., Lusk, K. A., Silcock, P., \& Bremer, P. J. (2017). Comparing PTR-MS profile of milk inoculated with pure or mixed cultures of spoilage bacteria. Food Microbiology.

Badeck, F.-W., Tcherkez, G., Nogués, S., Piel, C., \& Ghashghaie, J. (2005). Postphotosynthetic fractionation of stable carbon isotopes between plant organs - a widespread phenomenon. Rapid Communications in Mass Spectrometry, 19(11), 13811391.

Benjamini, Y., \& Hochberg, Y. (1995). Controlling the false discovery rate: a practical and powerful approach to multiple testing. Journal of the royal statistical society. Series $B$ (Methodological), 289-300.

Bergamaschi, M., Aprea, E., Betta, E., Biasioli, F., Cipolat-Gotet, C., Cecchinato, A., Bittante, G., \& Gasperi, F. (2015). Effects of dairy system, herd within dairy system, and individual cow characteristics on the volatile organic compound profile of ripened model cheeses. Journal of Dairy Science, 98(4), 2183-2196.

Bergamaschi, M., Biasioli, F., Cappellin, L., Cecchinato, A., Cipolat-Gotet, C., Cornu, A., Gasperi, F., Martin, B., \& Bittante, G. (2015). Proton transfer reaction time-of-flight mass spectrometry: A high-throughput and innovative method to study the influence of dairy system and cow characteristics on the volatile compound fingerprint of cheeses. Journal of Dairy Science, 98(12), 8414-8427.

Biolatto, A., Grigioni, G., Irurueta, M., Sancho, A. M., Taverna, M., \& Pensel, N. (2007). Seasonal variation in the odour characteristics of whole milk powder. Food Chemistry, 103(3), 960-967.

Buhr, K., van Ruth, S., \& Delahunty, C. (2002). Analysis of volatile flavour compounds by proton transfer reaction-mass spectrometry: fragmentation patterns and discrimination between isobaric and isomeric compounds. International Journal of Mass Spectrometry, $221(1), 1-7$.

Capuano, E., Grevink, R., Boerrigter-Eenling, R., \& van Ruth, S. M. (2015). Fatty acid and triglycerides profiling of retail organic, conventional and pasture milk: Implications for health and authenticity. International Dairy Journal, 42, 58-63.

Capuano, E., van der Veer, G., Boerrigter-Eenling, R., Elgersma, A., Rademaker, J., Sterian, A., \& van Ruth, S. M. (2014). Verification of fresh grass feeding, pasture grazing and organic farming by cows farm milk fatty acid profile. Food Chemistry, 164(0), 234-241. 
Cederberg, C., \& Mattsson, B. (2000). Life cycle assessment of milk production - a comparison of conventional and organic farming. Journal of Cleaner Production, 8(1), 49-60.

Chung, I.-M., Park, I., Yoon, J.-Y., Yang, Y.-S., \& Kim, S.-H. (2014). Determination of organic milk authenticity using carbon and nitrogen natural isotopes. Food Chemistry, 160(0), 214-218.

Croissant, A. E., Washburn, S. P., Dean, L. L., \& Drake, M. A. (2007). Chemical properties and consumer perception of fluid milk from conventional and pasture-based production systems. Journal of Dairy Science, 90(11), 4942-4953.

Ferreiro, T., Gayoso, L., \& Rodríguez-Otero, J. L. (2015). Milk phospholipids: Organic milk and milk rich in conjugated linoleic acid compared with conventional milk. Journal of Dairy Science, 98(1), 9-14.

Florence, A. C. R., Béal, C., Silva, R. C., Bogsan, C. S. B., Pilleggi, A. L. O. S., Gioielli, L. A., \& Oliveira, M. N. (2012). Fatty acid profile, trans-octadecenoic, $\alpha$-linolenic and conjugated linoleic acid contents differing in certified organic and conventional probiotic fermented milks. Food Chemistry, 135(4), 2207-2214.

Forss, D. A. (1979). Mechanisms of formation of aroma compounds in milk and milk products. Journal of Dairy Research, 46(04), 691-706.

Galle, S. A., Koot, A., Soukoulis, C., Cappellin, L., Biasioli, F., Alewijn, M., \& van Ruth, S. M. (2011). Typicality and Geographical Origin Markers of Protected Origin Cheese from The Netherlands Revealed by PTR-MS. Journal of Agricultural and Food Chemistry, 59(6), 2554-2563.

Gandy, A. L., Schilling, M. W., Coggins, P. C., White, C. H., Yoon, Y., \& Kamadia, V. V. (2008). The Effect of Pasteurization Temperature on Consumer Acceptability, Sensory Characteristics, Volatile Compound Composition, and Shelf-Life of Fluid Milk. Journal of Dairy Science, 91(5), 1769-1777.

Heck, J. M. L., van Valenberg, H. J. F., Dijkstra, J., \& van Hooijdonk, A. C. M. (2009). Seasonal variation in the Dutch bovine raw milk composition. Journal of Dairy Science, 92(10), 4745-4755.

Karatapanis, A. E., Badeka, A. V., Riganakos, K. A., Savvaidis, I. N., \& Kontominas, M. G. (2006). Changes in flavour volatiles of whole pasteurized milk as affected by packaging material and storage time. International Dairy Journal, 16(7), 750-761.

Křížová, L., Hanuš, O., Roubal, P., Kučera, J., \& Hadrová, S. (2013). The effect of cattle breed, season and type of diet on nitrogen fractions and amino acid profile of raw milk.

Makhoul, S., Yener, S., Khomenko, I., Capozzi, V., Cappellin, L., Aprea, E., Scampicchio, M., Gasperi, F., \& Biasioli, F. (2016). Rapid non-invasive quality control of semi-finished products for the food industry by direct injection mass spectrometry headspace analysis: 
the case of milk powder, whey powder and anhydrous milk fat. Journal of Mass Spectrometry, 51(9), 782-791.

Marian, L., Chrysochou, P., Krystallis, A., \& Thøgersen, J. (2014). The role of price as a product attribute in the organic food context: An exploration based on actual purchase data. Food Quality and Preference, 37, 52-60.

Masi, E., Romani, A., Pandolfi, C., Heimler, D., \& Mancuso, S. (2015). PTR-TOF-MS analysis of volatile compounds in olive fruits. Journal of the Science of Food and Agriculture, 95(7), 1428-1434.

Molkentin, J., \& Giesemann, A. (2010). Follow-up of stable isotope analysis of organic versus conventional milk. 398(3), 1493-1500.

Muñoz, N., Ortigosa, M. a., Torre, P., \& Izco, J. M. (2003). Free amino acids and volatile compounds in an ewe's milk cheese as affected by seasonal and cheese-making plant variations. Food Chemistry, 83(3), 329-338.

Nenadis, N., Heenan, S., Tsimidou, M. Z., \& Van Ruth, S. (2016). Applicability of PTR-MS in the quality control of saffron. Food Chemistry, 196, 961-967.

Pereda, J., Jaramillo, D. P., Quevedo, J. M., Ferragut, V., Guamis, B., \& Trujillo, A. J. (2008). Characterization of volatile compounds in ultra-high-pressure homogenized milk. International Dairy Journal, 18(8), 826-834.

Rios, J. J., Fernández-García, E., Mínguez-Mosquera, M. I., \& Pérez-Gálvez, A. (2008). Description of volatile compounds generated by the degradation of carotenoids in paprika, tomato and marigold oleoresins. Food Chemistry, 106(3), 1145-1153.

Routray, W., \& Mishra, H. N. (2011). Scientific and Technical Aspects of Yogurt Aroma and Taste: A Review. Comprehensive Reviews in Food Science and Food Safety, 10(4), 208220.

Schuhfried, E., del Pulgar, J. S., Bobba, M., Piro, R., Cappellin, L., Märk, T. D., \& Biasioli, F. (2016). Classification of 7 monofloral honey varieties by PTR-ToF-MS direct headspace analysis and chemometrics. Talanta, 147, 213-219.

Schwendel, B. H., Morel, P. C. H., Wester, T. J., Tavendale, M. H., Deadman, C., Fong, B., Shadbolt, N. M., Thatcher, A., \& Otter, D. E. (2015). Fatty acid profile differs between organic and conventionally produced cow milk independent of season or milking time. Journal of Dairy Science, 98(3), 1411-1425.

Sivadier, G., Ratel, J., Bouvier, F., \& Engel, E. (2008). Authentication of Meat Products: Determination of Animal Feeding by Parallel GC-MS Analysis of Three Adipose Tissues. Journal of Agricultural and Food Chemistry, 56(21), 9803-9812.

Sivadier, G., Ratel, J., \& Engel, E. (2010). Persistence of pasture feeding volatile biomarkers in lamb fats. Food Chemistry, 118(2), 418-425. 
Tornambé, G., Cornu, A., Pradel, P., Kondjoyan, N., Carnat, A., Petit, M., \& Martin, B. (2006). Changes in terpene content in milk from pasture-fed cows. Journal of Dairy Science, 89(6), 2309-2319.

Ueda, Y., Asakuma, S., Miyaji, M., \& Akiyama, F. (2015). Effect of time at pasture and herbage intake on profile of volatile organic compounds of dairy cow milk. Animal Science Journal, n/a-n/a.

Valero, E., Villamiel, M., Miralles, B., Sanz, J., \& Martínez-Castro, I. (2001). Changes in flavour and volatile components during storage of whole and skimmed UHT milk. Food Chemistry, 72(1), 51-58.

Vasta, V., \& Priolo, A. (2006). Ruminant fat volatiles as affected by diet. A review. Meat Science, 73(2), 218-228.

Veronika, R., Wolfgang, L., Christoph, S., Bogdan, C., Klaus, R. L., \& Anton, A. (2014). Non13 CO 2 targeted breath tests: a feasibility study. Journal of Breath Research, 8(4), 046005.

Villeneuve, M. P., Lebeuf, Y., Gervais, R., Tremblay, G. F., Vuillemard, J. C., Fortin, J., \& Chouinard, P. Y. (2013). Milk volatile organic compounds and fatty acid profile in cows fed timothy as hay, pasture, or silage. Journal of Dairy Science, 96(11), 7181-7194.

Willer, H., \& Lernoud, J. (2015). The world of organic agriculture 2015: Summary. The world of organic agriculture: Statistics and emerging trends, 119-124.

Zhao, H., Guo, B., Wei, Y., \& Zhang, B. (2012). Effects of Wheat Origin, Genotype, and Their Interaction on Multielement Fingerprints for Geographical Traceability. Journal of Agricultural and Food Chemistry, 60(44), 10957-10962. 
CHAPTER 6 


\section{Chapter 7}

General discussion 


\subsection{Overview}

The major aim of the current thesis was to elucidate the differences in characteristics of organic milk and other milks and to study their underlying causes. Subsequently, the confirmed traits could be applied in the authentication of different milks. In this chapter, the findings from Chapter 2-6 are integrated to answer the research questions of this thesis as stated in the general introduction (Chapter 1). First the results on fatty acid (FA) composition of milk are discussed, which are then followed by those for the volatile organic compounds (VOCs). Afterwards, these approaches are compared and final conclusions drawn. Finally, recommendations for further research are given at the end of this chapter.

\subsection{Unique fatty acid (FA) features of different milks and the causes of these features}

\subsubsection{FA features of different milks}

In this thesis, the characteristics of the FA profiles of organic, pasture, and conventional milks were studied in Chapter 2 and 4.

In Chapter 2, the FA profiles of farm milks from different systems in summer and winter were investigated. In summer, the levels of polyunsaturated fatty acid (PUFA), C18:3n3, and conjugated linoleic acid (CLA) were significantly higher $(\mathrm{P}<0.05)$ in organic milk than the levels of those FAs in pasture and conventional milk. On the contrary, the FAs that showed significant differences between winter organic milk and winter milks from other production systems did not show similar differences in summer milks. However, distinct and different distribution patterns were observed for the winter organic milk and the other winter milks in the principal component analysis (PCA) plot (Fig. 2.2). Furthermore, to investigate if differences between summer organic farm milk and other summer farm milks would exist in retail milk, the FA profiles of different summer retail milks were analysed in Chapter 4. The results suggested that the concentrations of major FAs (groups), including C14:1n5, C15:0, C16:1n7, C17:0, C17:1n7, CLA, C18:3n3, and SFA, showed significant different levels between summer organic retail milk and summer retail milks from other production systems. Hence, CLA and C18:3n3 could be potential markers to separate organic milk from other milks in summer, as these consistently differed both in farm and retail milks.

\subsubsection{Factors leading to the FA features}

In winter, most of the Dutch dairy farmers (including organic, pasture, and conventional dairy farmers) keep their cows indoor, providing cows with silages. Nevertheless, the types of silages provided in the farms from different dairy systems differ. Pasture and conventional farmers provided silages with grass and maize. This is because a higher amount of maize in diets increases the milk yield and milk protein content (Khan, Yu, Ali, Cone, \& Hendriks, 2015; 
Elgersma, Ellen, van der Horst, Boer, Dekker, \& Tamminga, 2004; O'Mara, Fitzgerald, Murphy, \& Rath, 1998). This makes sense, since farmers in the Netherlands are paid according to the total protein and total fat content of the milk. On the other hand, organic dairy farmers tend to provide silages without maize, i.e. silages with the plants from their grasslands only. This is mainly due to the limited production of organic maize. This limited production leads to a higher price of organic maize, which deems it financially unsuitable for increasing protein contents in organic milk. Such an economic reason leads to the differences of silage compositions between organic dairy farms and other dairy farms. On the other hand, according to Table 2.3, fatty acids did not show significant differences between different winter farm milks, which suggests that the prevailing different grass/maize proportions in the silages did not significantly affect the FA compositions of milks. This is in contradiction with the findings in other studies (Kliem, Morgan, Humphries, Shingfield, \& Givens, 2008), which indicated a significant change when the percentages of maize in silage increased from zero to $100 \%$. In our study, only few FAs demonstrated significant differences between winter organic silages and others, which is primarily due to the large variance among silages. As a consequence, resulting milks did not differ much in their FA compositions either. The PCA plot of the FA profiles of different forages in Chapter 2 (Fig. 2.1) supports this hypothesis. The widespread distribution of the silages indicates a great variation in the FA composition of silages between farms, which in turn leads to widespread FA profiles of milks from farms within the same dairy system.

In Chapter 2, the impact of grazing management on the FA profiles of different milks has also been examined. In the Netherlands, cows in organic, pasture, and conventional farms all stayed indoors in winter.

Meanwhile, in summer, cows in organic farms were free to graze outside during the day, on average more than 8 hours; cows in pasture farms partly grazed outside, ranging from 4 hours to 8 hours; cows in conventional farms stayed indoors during day and night in our study. According to the results of the pairwise comparisons (Table 2.3) and PCA plot (Fig. 2.2), the differences of the FA profiles between different milks in summer were more distinct. Furthermore, according to the PCA plot, summer pasture milk samples were positioned between summer organic milk and summer conventional milk. This aligns with the level of grazing in the different farming systems. Similar results were observed in the analysis of the retail milks (Table 4.1 and Fig. 4.2). In Fig. 4.2, summer pasture retail milk samples were also positioned between summer organic retail milk and summer retail conventional milk. Combining the PCA plots and pairwise comparisons, it could be concluded that the impact of grazing periods on FA profiles exceeded the impact of different silage types, which is in accordance with findings reported by Kalač and Samková (2010). Moreover, milk from speciesrich grasslands has been proven to have a considerably higher ratio of unsaturated fatty acids (UFAs) to saturated fatty acids (SFAs) than species-poorer grasslands, especially CLA and vaccenic acid (Dewhurst, Evans, Scollan, Moorby, Merry, \& Wilkins, 2003; Van Dorland, 
Kreuzer, Leuenberger, \& Wettstein, 2008). Furthermore, since synthetic fertilizers are not allowed in organic grassland management, some legumes are cultivated to provide extra nitrogen for the grassland, which increases the amount of UFAs in summer organic milk, and those legume forages increase the protection of lipids from endogenous lipolytic activity (Buccioni, Decandia, Minieri, Molle, \& Cabiddu, 2012). Hence, these things all contribute to a higher level of unsaturated UFAs in organic milk.

According to the results in Chapter 2 and Chapter 4, the concentrations of C18:3n3, CLA and PUFA showed significant differences between organic milk and other farm milks in summer. Similarly, the differences of the concentrations of these three FAs were significant different between organic retail milk and other retail milks as well. This suggests that the differences remain visible after industrial processing, which is in accordance with the findings reported by Fidler, Sauerwald, Demmelmair, and Koletzko (2001), who suggested that pasteurization does not cause considerable changes in milk FA compositions.

Furthermore, except C18:3n3 and CLA, there were 25 other FAs (groups) (e.g. C14:1n5, $\mathrm{C} 15: 0, \mathrm{C} 16: 1 \mathrm{n} 7, \mathrm{C} 17: 0, \mathrm{C} 17: \ln 7)$ that showed significant differences between organic retail milk and other retail milks. These significant differences were not observed when the comparison was carried out between organic farm milk and other farm milks. This phenomenon may be explained by the specific farm milk being processed into the retail milk. Since pasture milk regulation does not specify when the cows must be outdoors as long as cows are on pasture at least 120 days per year, it can happen that pasture retail milk came from farms that had cows indoors and outdoors at the same time. In this case, retail pasture milk was closer to retail conventional milk. According to the results of Chapter 2, many FAs showed significant differences between organic farm milk and conventional raw milk, including most of the FAs showing significant differences between organic retail milk and other retail milks.

\subsubsection{Features of near infrared (NIR) spectrum related to FA profiles}

Fourier transform near-infrared spectroscopy (FT-NIR), micro near infrared spectroscopy (Micro-NIR) and a hand-held shortwave near infrared device named SCIO, were used to investigate the characteristic molecular vibrations (including overtones and combinations) of different milks in Chapter 4 and Chapter 5. The molecular vibrations are related to the bonds of $\mathrm{C}-\mathrm{C}, \mathrm{C}=\mathrm{C}, \mathrm{C}-\mathrm{H}, \mathrm{H}-\mathrm{O}$, etc., which indicate the concentrations of some organic compounds, including FAs. Hence, the features of NIR spectra in certain wavelength ranges could be treated as the derived characteristics of the FA profiles of different milks. From the results of Fig. 4.1, the main ranges where organic milk was separated from milks from other production systems were $1492-1887 \mathrm{~nm}$ and 2083-2381 nm. According to the findings of Westad, Schmidt, \& Kermit (2008), the peak in the range of 1600-1850 nm originate from the first overtone of methyl and methylene groups while the peak in the range of 2050-2230 is related to the combination ( $1^{\text {st }}$ overtone, $2^{\text {nd }}$ overtone, and stretching) of methyl. Based on the 
results in Fig. 4.3, the spectral information of these two wavelength ranges is highly related to the concentration of $\mathrm{C} 18: 1 \mathrm{n} 9$ cis and $\mathrm{C} 14: 1 \mathrm{n} 5$. Nevertheless, since the level of C18:1n9 cis is not significantly different between organic milk and pasture milk (Table 4.1), the discriminant model that was built based on NIR spectra, could distinguish organic milk from conventional milk, but not from pasture milk.

\subsection{Unique VOC features of different milks and the causes of the features}

\subsubsection{VOC features of different milks}

In the current thesis, the characteristics of the VOC profiles of organic, pasture, and conventional milks were studied in Chapter 3 and 6.

In Chapter 3, the differences of VOC profiles between different farm milks in summer and winter was investigated. Seventy-eight masses showed significant differences, among which are propene, acetone, and 2-butanone as the predominant masses (Table 3.3). The concentration of acetone showed significant differences between milks from summer and winter only. The levels of acetone of milks collected in the same season, but from different dairy systems, were not significantly different. Propene could tell the differences between organic, pasture, and conventional milks only in summer, whereas 2-butanone could tell the differences between organic and conventional milks only in winter. In terms of the overall differences, Fig. 3.2 showed the patterns of milks from different production systems in winter and summer. In summer, organic milk could be distinguished from pasture milk and conventional milk, while in winter, organic milk could only be distinguished from conventional milk. Furthermore, the distribution of different milks is more spread in summer than in winter, suggesting larger variance in summer. In Chapter 6, a similar study was carried out with different retail milks collected in summer and winter. A lower number of masses showed significant differences between milks from different dairy systems and seasons than for the farm milks. Isoprene was the most abundant compound which showed significant differences between milks from different systems, while 2-butanone was the most abundant compound showing significant differences between milks from summer and winter. This matched the results observed for the farm (raw) milks. Hence, the concentration of 2-butanone could serve as an indicator of the authenticity of organic milk. However, compared with the overall differences between various farm milks, the differences are less significant between various retail milks (Fig. 6.2).

\subsubsection{Factors leading to the VOC features}

According to the results in Table 3.2, heptanal is the only mass which showed significant differences between winter organic milk and winter milks from other production systems. As was discussed in 7.2.2, winter organic milk was derived from cows fed with grass silages, while other milks were derived from cows fed with grass, and maize silages. One of the main 
constituents showing significant differences between milks from different silages was 2butanone. This result is in line with a previous study (Toso, Procida, \& Stefanon, 2002) wherein different levels of 2-butanone in milks from different diets (hay, maize silage, and grass silage) were observed. They reported discrimination of milks produced by cows fed maize silages and grass silages by the concentration of ethanol and hexanal as well. However, in the current thesis no significant differences of these two compounds were observed. Although the number of masses that showed significant differences between winter organic milk and other winter milks was limited, a clear demarcation between winter organic milk and winter milks from other production systems was observed when comparing VOC patterns (Fig. 3.2). A similar trend was found between the different retail milks. In Fig. 6.2, the winter organic milk could be easily distinguished from winter conventional milk.

According to the results in Table 3.2, when the comparison was carried out between winter milks and summer milks, a significant difference of the concentrations of propene was observed. Propene is a fragment of terpenes that is indicative of the amount of fresh plants in the diets (Infantino, Costa, Aragona, Reverberi, Taiti, \& Mancuso, 2017). Summer organic, pasture, and conventional milks came from fully grazing, partly grazing, and non-grazing systems, respectively. Hence, the levels of propene would be expected to reflect the fresh grass intake. Furthermore, since usage of herbicides is not allowed in organic grasslands, the forage species in organic farm feeds were expected to be more diverse than the species in pasture farms (Battini, Agostini, Tabaglio, \& Amaducci, 2016; Hansen, Alrøe, \& Kristensen, 2001). Similar results have been found in previous research (Fedele, Pizzillo, Claps, \& Cifuni, 2007), which indicates that the abundance of botanical species in the forage diet has a significant impact on the milk terpenes profile.

Besides specific compounds, some trends could be observed from the overall differences of the VOC profiles of milks produced with different grazing levels (Fig. 6.2). Summer conventional milk was closer to winter milks and summer pasture milk was in between summer conventional milk and summer organic milk, which matches the trends of the changes of grazing levels related to each production system. Grazing level was highest in summer organic farms, followed by summer pasture farms, while it decreased to the lowest level in summer conventional farms and all the winter farms.

Comparing Fig. 3.2 and Fig. 6.2, we notice that industrial processing did not entirely cover up the differences of the VOC profiles of the milks from the different production systems. However, the variation of different summer farm milks was higher than that of summer retail milks (Fig. 3.2 and Fig. 6.2). This can be due to the various processing steps as mentioned before (Gandy, Schilling, Coggins, White, Yoon, \& Kamadia, 2008; Karatapanis, Badeka, Riganakos, Savvaidis, \& Kontominas, 2006). As an unavoidable step in the processing, pooling of the milk may lead to the disappearance of some characteristics of individual samples. Thus, 
industrial processing could narrow down the differences between the VOC profiles of different milks, but it did not completely erase the significant differences.

\subsection{Comparison between different detection approaches}

In the current thesis, FA and VOC traits of milks and feeds were examined with six different types of instruments, including gas chromatography (GC), proton transfer reaction quadrupole mass spectrometry (PTR-(Quad)MS), proton transfer reaction time of flight mass spectrometry (PTR-(ToF)MS), FT-NIR, Micro-NIR, and SCIO. These various approaches are compared for a number of criteria in Table 7.1. GC was used to investigate the FA profiles of different milks. The current study and some previous studies have proven its ability to distinguish organic milk from other milks. Meanwhile, according to the results in Chapter 2 and Chapter 4, the signal intensities and retentions time were stable. Nevertheless, the operation of the GC instrument needs well-trained technicians. Furthermore, a low portability and a relatively high price limits the application of this method. Next to GC, PTR-(Quad)MS and PTR-(ToF)MS were used to investigate the characteristics of the VOC profiles of different milks. Owing to a specially crafted high-end orthogonal acceleration reflection time of flight, a higher mass resolution could be achieved, which facilitates the identification of VOCs. Such characteristics allow PTR-(ToF)MS to distinguish organic milk from other milks. Due to the lower resolution, the discriminatory capacity of PTR-(Quad)MS is not as strong as the capacity of GC and PTR-(ToF)MS. However, the stability of PTR(Quad)-MS is better than that of PTR(ToF)MS. Since PTR-(Quad)MS and PTR-(ToF)MS belong to the group of direct inject mass spectrometry, both require hardly any pre-treatments of samples. However, in terms of portability, the size of these two instruments limits application in the field. Additionally, the high price is another barrier for the widespread application of these instruments, especially for PTR-(ToF)MS.

Besides these benchtop analytical instruments, some fast scanning instruments have been explored in this thesis. These spectral instruments could indirectly discriminate organic milk from other milks based on the FA profiles. In Chapter 4, the discriminatory ability of GC, FT-NIR and micro-NIR was compared. The results showed that when the comparison was carried out between organic milk and other milks (including conventional and pasture milk), GC had significantly stronger discriminatory ability, while when the comparison was carried out between organic milk and conventional milk, these three instruments (GC, FT-NIR, and micro-NIR) did not show a significantly different ability in distinction of the milks. In Chapter $\mathbf{5}$, the discriminatory capacity of a consumer NIR device, SCIO, was examined. Since these three instruments are based on spectra, the signal drift could not be avoided. Hence, the stability of FT-NIR, Micro-NIR, and SCIO was poorer than those of GC and PTR-(Quad/ToF)MS instruments. However, as a type of rapid non-destructive detection method, these NIR based method do not need extra preparations. Samples could be scanned by the instruments directly, 
especially for micro-NIR and SCIO. These handheld devices could be easily operated by inexperienced users, to identify products. The size of Micro-NIR and SCIO is much smaller than the size of FT-NIR and PTR-(ToF)MS.

Table 7.1 Characteristics of different detection approaches.

\begin{tabular}{|c|c|c|c|c|c|c|}
\hline & $\begin{array}{l}\text { Target } \\
\text { group }\end{array}$ & $\begin{array}{l}\text { Discriminatory } \\
\text { capacity }\end{array}$ & Stability & $\begin{array}{l}\text { Complexity of } \\
\text { operation }\end{array}$ & Portability & Price \\
\hline $\mathrm{GC}^{*}$ & $\begin{array}{l}\text { FA } \\
\text { profiles }\end{array}$ & & & & & \\
\hline $\begin{array}{l}\text { PTR- } \\
\text { (Quad)MS }\end{array}$ & $\begin{array}{l}\text { VOC } \\
\text { profiles }\end{array}$ & & & & & \\
\hline $\begin{array}{l}\text { PTR- } \\
(\mathrm{ToF}) \mathrm{MS}\end{array}$ & $\begin{array}{l}\text { VOC } \\
\text { profiles }\end{array}$ & & & & & \\
\hline FT-NIR & $\begin{array}{l}\text { Molecular } \\
\text { vibrations }\end{array}$ & & & & & \\
\hline Micro-NIR & $\begin{array}{l}\text { Molecular } \\
\text { vibrations }\end{array}$ & & & & & \\
\hline SCIO & $\begin{array}{l}\text { Molecular } \\
\text { vibrations }\end{array}$ & & & & & \\
\hline
\end{tabular}

Negative

Positive

*GC: gas chromatography; PTR-(Quad)MS: proton transfer reaction quadrupole mass spectrometry; PTR-(ToF)MS: proton transfer reaction time of flight mass spectrometry; FT-NIR: Fourier transform near infrared spectroscopy; Micro-NIR: micro near infrared spectroscopy; SCIO: hand held shortwave near infrared spectroscopy.

These portable devices could be applied at farms and dairy factories by operators in the dairy supply chain, authorities, inspection, and certification bodies. The deployment of analysis instruments in the field will help to combat fraud in the different tiers of the supply chain.

Based on the identified markers, laboratory based analytical instruments could provide powerful discriminatory capacity. However, limited by their size and cost, those instruments can only be operated in advanced labs. Portable instruments like Micro-NIR and SCIO could be applied anywhere in the supply chain with a certain level of specificity.

Hence, users could select a suitable approach based on specific requirements and conditions. For instance, users who aim to confirm the authenticity of organic milk (e.g., food authorities), should adopt one of the precise approaches, such as GC and PTR(Quad)/(TOF)MS. For users who need to routinely screen products (e.g., quality control departments in companies), FT-NIR and Micro-NIR may be superior to other approaches. Micro-NIR, which could be easily operated in the field, is the proper approach to inspect tank milks before adding them into pools. SCIO, due to its low cost and overall performance, is more suitable for consumers, who would like to know more about the products. 


\subsection{Final conclusions}

The objectives of this $\mathrm{PhD}$ thesis were to elucidate the differences between organic milk and milks from other production systems (in regard to their FA and VOC compositions), explore the causes of the differences, and rank analysis approaches for various stakeholder groups. According to the results described in the previous sections, the following conclusions are drawn:

FA compositions show significant differences between organic farm milk and milks from other production systems in summer, while the FA profiles of different winter milks could only be distinguished with the help of pattern recognition tools. On the other hand, VOC profiles show significant differences between different milks both in summer and winter.

The type of forages and the level of grazing contribute to the differences of FA and VOC compositions, but the latter one has a larger impact on the milk composition. Meanwhile, industrial processing and pooling reduces, but not erases, the significant differences between organic milk and milks from other production systems.

GC and PTR-MS could discriminate organic milk from pasture milk and conventional milk, while FT-NIR and micro-NIR can only distinguish organic milk from conventional milk. The former approaches are the options of organic milk identity confirmation, while the latter approaches are more suitable for fast screening. Micro-NIR and SCIO could be adopted when the detection needs to be conducted in the field.

\subsection{Research limitations and recommendations for future research}

The studies described in this thesis investigated the characteristics of different milks and underlying causes, and attempted to discriminate organic milk from milks from other production systems by using different approaches. Nevertheless, there are a number of limitations. Regarding future studies to improve the classification of different milks and have a clearer understanding of the factors leading to the characteristics of different milks, some suggestions could be given:

\section{- Investigate the FA profiles and NIR spectra of winter retail milks}

In this thesis, the FA profiles and NIR spectra of winter retail milks were not investigated. Although there were no significant differences found between organic farm milk and other farm milks in winter, FA profiles and NIR spectra of winter retail milks could help to build an assembling model for organic milk classification.

\section{- Investigate the characteristics of manure and soil}

Future research could, next to milk and feed, further investigate the characteristics of manure and soil at the farms of different farming systems. This is because soil conditions could affect the properties of plants and reflect the ways of farming practice. Meanwhile, the characteristics of manure could provide extra information of the daily intake and health 
conditions of cows. The characteristics of manure and soil could be used to explain the characteristics of feeds and subsequent milks. Linking soil, feed, milk, and manure will provide a better understanding of the natural life-cycle in each farming system. It could further confirm the characteristics of each farming system.

\section{- Enlarge scope and validate the models with larger sample sizes}

As well known, an extensive dataset could help to build a robust classification model. In future studies, more samples should be collected to evaluate the impact of other factors in different dairy farms. Furthermore, in the current research, the samples were collected from the farms and markets in the Netherlands. However, considering the variance in climate, landscape, and culture, the characteristics of milks could be different in other countries. Including samples from different countries could be helpful to create an overall pattern of the FA and VOC characteristics of organic milk for the whole of Europe.

\section{- Adopt more advanced sensors and more robust algorithms}

In Chapter 5, a smartphone equipped with an external device was used to discriminate organic milk from other milks. Compared with laboratory-based approaches, this fast scanning technology is still at the development stage. In the future, better sensors may become available and more or other algorithms could be applied to increase signal/noise ratio (e.g. wavelet analysis, orthogonal signal correction, etc), to extract spectral features (e.g. independent component analysis, genetic algorithm, etc.), and to improve the performance of the classification models (e.g. random forest, artificial neural network, etc.).

The authenticity of different milks is important for consumers, farmers, dairy companies, and other stakeholders within the dairy sector. It is not only related to a premium price for a specific production system, but it is also about public confidence of purchasing labelled products. Although there are some limitations, the current research filled several gaps in existing knowledge regarding the FA and VOC profiles of different milks and related feeds, as well as regarding factors leading to the unique profiles. Furthermore, the development of novel analysis approaches makes it possible to discriminate different milks beyond the lab. The author hopes the current research provides a new perspective and stimulates future research and applications. 


\subsection{References}

Battini, F., Agostini, A., Tabaglio, V., \& Amaducci, S. (2016). Environmental impacts of different dairy farming systems in the Po Valley. Journal of Cleaner Production, 112, 91-102.

Buccioni, A., Decandia, M., Minieri, S., Molle, G., \& Cabiddu, A. (2012). Lipid metabolism in the rumen: New insights on lipolysis and biohydrogenation with an emphasis on the role of endogenous plant factors. Animal Feed Science and Technology, 174(1), 1-25.

Capuano, E., Grevink, R., Boerrigter-Eenling, R., \& van Ruth, S. M. (2015). Fatty acid and triglycerides profiling of retail organic, conventional and pasture milk: Implications for health and authenticity. International Dairy Journal, 42, 58-63.

Dewhurst, R. J., Evans, R. T., Scollan, N. D., Moorby, J. M., Merry, R. J., \& Wilkins, R. J. (2003). Comparison of grass and legume silages for milk production. 2. In vivo and in sacco evaluations of rumen function. Journal of Dairy Science, 86(8), 2612-2621.

Elgersma, A., Ellen, G., van der Horst, H., Boer, H., Dekker, P. R., \& Tamminga, S. (2004). Quick changes in milk fat composition from cows after transition from fresh grass to a silage diet. Animal Feed Science and Technology, 117(1), 13-27.

Fedele, V., Pizzillo, M., Claps, S., \& Cifuni, G. (2007). Effect of types of forage on terpenes content and profile in goat milk. Options Méditerranéennes A, 74, 19-24.

Fidler, N., Sauerwald, T. U., Demmelmair, H., \& Koletzko, B. (2001). Fat Content and Fatty Acid Composition of Fresh, Pasteurized, or Sterilized Human Milk. In D. S. Newburg (Ed.), Bioactive Components of Human Milk (pp. 485-495). Boston, MA: Springer US.

Gandy, A. L., Schilling, M. W., Coggins, P. C., White, C. H., Yoon, Y., \& Kamadia, V. V. (2008). The Effect of Pasteurization Temperature on Consumer Acceptability, Sensory Characteristics, Volatile Compound Composition, and Shelf-Life of Fluid Milk. Journal of Dairy Science, 91(5), 1769-1777.

Hansen, B., Alrøe, H. F., \& Kristensen, E. S. (2001). Approaches to assess the environmental impact of organic farming with particular regard to Denmark. Agriculture, Ecosystems \& Environment, 83(1-2), 11-26.

Infantino, A., Costa, C., Aragona, M., Reverberi, M., Taiti, C., \& Mancuso, S. (2017). Identification of different fusarium spp. through mVOCs profiling by means of protontransfer-reaction time-offlight (PTR-TOF-MS) analysis. Journal of plant pathology, 99(3), 663-669.

Kalač, P., \& Samková, E. (2010). The effects of feeding various forages on fatty acid composition of bovine milk fat: A review. Czech Journal of Animal Science, 55(12), 521-537.

Karatapanis, A. E., Badeka, A. V., Riganakos, K. A., Savvaidis, I. N., \& Kontominas, M. G. (2006). Changes in flavour volatiles of whole pasteurized milk as affected by packaging material and storage time. International Dairy Journal, 16(7), 750-761. 
Khan, N. A., Yu, P., Ali, M., Cone, J. W., \& Hendriks, W. H. (2015). Nutritive value of maize silage in relation to dairy cow performance and milk quality. Journal of the Science of Food and Agriculture, 95(2), 238-252.

Kliem, K. E., Morgan, R., Humphries, D. J., Shingfield, K. J., \& Givens, D. I. (2008). Effect of replacing grass silage with maize silage in the diet on bovine milk fatty acid composition. Animal, 2(12), 1850-1858.

Mohd-Setapar, S., Abd-Talib, N., \& Aziz, R. (2012). Review on crucial parameters of silage quality. APCBEE Procedia, 3, 99-103.

O'Mara, F. P., Fitzgerald, J. J., Murphy, J. J., \& Rath, M. (1998). The effect on milk production of replacing grass silage with maize silage in the diet of dairy cows. Livestock Production Science, 55(1), 79-87.

Oudshoorn F W, Sørensen C A G, de Boer I J M. Economic and environmental evaluation of three goal-vision based scenarios for organic dairy farming in Denmark[J]. Agricultural systems, 2011, 104(4): 315-325.

Toso, B., Procida, G., \& Stefanon, B. (2002). Determination of volatile compounds in cows' milk using headspace GC-MS. Journal of Dairy Research, 69(4), 569-577.

Van Dorland, H. A., Kreuzer, M., Leuenberger, H., \& Wettstein, H. R. (2008). Comparative potential of white and red clover to modify the milk fatty acid profile of cows fed ryegrass-based diets from zero-grazing and silage systems. Journal of the Science of Food and Agriculture, 88(1), 77-85.

Westad, F., Schmidt, A., \& Kermit, M. (2008). Incorporating chemical band-assignment in near infrared spectroscopy regression models. Journal of near infrared spectroscopy, 16(3), 265-273. 


\section{Summary}

Organic milk has been receiving more and more attention in recent years. However, it is also susceptible to fraud considering its high retail price and the strict requirements of organic production. Since the quality of milk is affected by many factors, such as seasons, environment, lactation stage, feed, cow breed, etc., it is challenging to distinguish organic milk from conventional milk. To ensure fair competition and consumer confidence, there is a strong need to confirm the identity of organic products including milk. Therefore, this study was carried out to elucidate the differences in characteristics, in terms of fatty acid (FA) and volatile organic compound (VOC) profiles, of organic milk and other milks, and to study their underlying causes.

In Chapter 2 and Chapter 4, the FA profiles of different farm (raw) milks and retail milks were investigated by gas chromatography (GC). Both the types of silages and grazing management strategies in different dairy production systems impacted on the FA profiles of milks, where the impact of the latter one was more significant. Corresponding to this result for farm (raw) milks, the differences of the FA profiles of different milks have also been observed among retail milks. Hence, industrial processing and milk pooling did not erase all the characteristics of organic milks. However, due to the relatively flexible regulations of pasture milk, the differences between pasture retail milk and conventional retail milk were less significant than the differences between pasture raw milk and conventional raw milk.

Similarly, the VOC profiles of raw milks and retail milks were analysed in Chapter 3 and Chapter 6. By using proton transfer reaction quadrupole mass spectrometry (PTR(Quad)MS) and proton transfer reaction time of flight mass spectrometry (PTR-(ToF)MS), the characteristics of different milks in winter and summer were investigated. Similar to the results of FA analysis, the grazing management had a greater impact on VOC profiles than the type of silages. This is not only due to the VOCs resulting from the feedstuff consumed by the cows, but relates also to the FA composition of the milks. Moreover, the characteristics of the VOC profiles of retail milks were investigated as well, which revealed that the differences between milks from organic and other production systems in summer and winter could still be observed.

In general, pasture milk was closer to conventional milk in winter and closer to organic milk in summer, in terms of its FA profile and VOC profile, whereas the differences between organic milk and conventional milk were significant both in summer and winter. 
Subsequently, different analysis approaches were compared for various stakeholders. PTR-(ToF)/(Quad)MS and GC told the differences between organic milk and milks from other production system (including conventional and pasture systems). They provide options for the authorities to confirm the authenticity of organic milk. Fourier transform near-infrared spectroscopy (FT-NIR) and micro near infrared spectroscopy (Micro-NIR) could distinguish organic milk from conventional retail milk but not from pasture milk. They can provide a first, on site check of the identity of organic milk. The novel handheld near-infrared spectroscopy, $\mathrm{SCIO}$, can be easily operated by consumers and generate some relevant information of the products.

The results of this study could contribute to the authenticity of organic milk and help protect the rights of stakeholders. 


\section{Acknowledgements}

This thesis is the result of much work and collaboration with some brilliant people around me during 2014-2019, but I would like to give my deepest thanks to Prof. dr Saskia van Ruth. Professor van Ruth helped me since the application of the $\mathrm{PhD}$. We discussed about the project, exchanged the ideas, drafted the proposal, and finally, we made it come true. Without your help, the project could not have been initiated. During my PhD period, Saskia helped me to improve more than a lot of scientific skills which made me understand the true meaning of a scientist. I would like to give my deepest gratitude to you, Saskia.

Meanwhile, I would like to thank to another two other supervisors, Dr Kasper Hettinga and Dr Annemieke Pustjens not only for your suggestions, comments, criticism, and guidance, but also for your inspiration, patience, and encouragement.

I also want to deeply thank Alex Koot, Rita Boerrigter-Eenling, and Michiel Wijtten for all dedication and time spent with me during my lab days, especially for helping and teaching me to operate the PTR-MS and GC systems. Many thanks to Martin Alewijn for sharing knowledge on chemometrics with me and helping me with the issues related to statistics. Then I would like to thank my students, Hector, Ziyan, and Isebel. We went to the farms, did experience, and generated great ideas together. It was a wonderful time.

I would also like to thank to my best office mates, Valentina, Isabelle, Yuzheng, and Jing. We encouraged each other, supported each other and learnt from each other. I cannot imagine what my $\mathrm{PhD}$ life would have looked like without you.

A word of gratitude goes to my great colleagues in WFSR, Eric, Erwin, Piet, Linda, Dave, Erika, Tjerk, Yannick, Leen, Robert, Lonneke, Ine, Paulien, Marko, Esther, Elise Hoek, Elise Gerrits, Jennifer, Lukas, Rosan, Yvette, Nathan, Leonieke, Amelia, Wenjuan, Arjen, Lennert, Irene, Jannie, Cheng, Hans, Anand, and Yamine, as well as the colleagues in FQD, Vincenzo, Kimberley, Corine, Edoardo, Frans, Erik, Mohammad, Alim, Ayusta, Moheb, James, Onu, Hannah, Sara, Mostafa, Pieter, Sine, Sara, Eva, Sergio, and Alfred. Guys, you are really nice and fun to be with! Loved to have met you. Furthermore, many thanks to my Chinses friends in Wageningen, Chunyue, Hongwei, Ling, Zhijun, Lijiao, Zhan, Lintianxiang, Li, Hao, Jianing, Yajing, Fahui, Min, Wei, Peiyu, and Hao.

To my beloved family that helped me during my PhD life: you are always my backup, not only in my PhD, but also in my whole life. I love you. 谢谢亲爱的爸爸妈妈。一路走来, 你们一直默默支持着我。从南昌, 到北京, 再到荷兰, 我慢慢长大, 也离家越来越远。 
每年在一起的时间也变得越来越短。可是，即使这样，你们对我的支持也从未改变。 感谢你们的理解与牺牲, 感谢你们给予我的一切。谨以此书献给我最爱的父母。 


\section{About the author}

Ningjing Liu was born in Nanchang, Jiangxi Province, China on the $12^{\text {th }}$ October 1990 . He finished his bachelor degree in Food Quality and Safety at China Agriculture University in 2011, after which he started his Master degree in Food Engineering and graduated in 2014. In October 2014, Ningjing started his Doctoral studies on the topic of organic milk authenticity in the Food Quality and Design group and Wageningen Food Safety Research at Wageningen University and Research. The results of this research are described in this thesis. Ningjing's main research interests cover topics in analytical chemistry and data analysis. In 2018 he started working at Wageningen Food Safety Research as a researcher in the BU Toxicology, Novel foods and Agrochains. 


\section{List of publications}

Ningjing Liu, Alex Koot, Kasper Hettinga, Jacob de Jong, Saskia M. van Ruth, Portraying and tracing the impact of different production systems on the volatile organic compound composition of milk by PTR-(Quad)MS and PTR-(ToF)MS, Food Chemistry, Volume 239, 2018, 201-207.

Ningjing Liu, Hector Aya Parra, Annemieke M. Pustjens, Kasper Hettinga, Philippe Mongondry, Saskia M. van Ruth, Evaluation of portable near-infrared spectroscopy for organic milk authentication, Talanta, Volume 184, 2018, 128-135.

Ningjing Liu, Annemieke M. Pustjens, Sara W. Erasmus, Yuzheng Yang, Kasper Hettinga, Saskia M. van Ruth, Dairy farming system markers: The correlation of forage and milk fatty acid profiles from organic, pasture and conventional systems in the Netherlands, Food Chemistry, Volume 314, 2020, 126153.

Ningjing Liu, Annemieke M. Pustjens, Kasper Hettinga, Saskia M. van Ruth, Tracking volatile organic compounds from forage to milk for different production systems, submitted.

Saskia van Ruth \& Ningjing Liu, How organic is organic milk? Can we have a quick check? NIR news, Volume 30, 2019, 18-21.

Valentina Acierno, Ningjing Liu, Martin Alewijn, Markus Stieger, Saskia M. van Ruth, Which cocoa bean traits persist when eating chocolate? Real-time nosespace analysis by PTR-QiToFMS, Talanta, Volume 195, 2019, 676-682.

Yuzheng Yang, Wim Huisman, Kasper Hettinga, Ningjing Liu, Jeroen Heck, Saskia van Ruth, Fraud vulnerability in the Dutch milk supply chain: Assessments of farmers, processors and retailers, Food Control, Volume 95, 2019, 308-317. 


\section{Overview of completed training activities}

\section{Discipline specific activities}

Advanced Food Analysis (2015), VLAG, Wageningen, NL.

Dutch Dairy Chain (2015), WA, Leeuwarden, NL.

Sensory perception and food preference: Affective drivers of food choice (2016), VLAG, Wageningen, NL.

10th European Organic Congress (2016), IFOAM, Driebergen, NL.

3rd NVMS-BSMS Conference on Mass (2016), NVMS, Kerkrade, NL.

Chemometrics (2016), VLAG, Wageningen, NL.

Dairy Conference (2016), IDF, Rotterdam, NL.

China International Food Safety \& Quality Conference (2017), IAFP, Shanghai, CN.

Postgraduate Food Fraud Symposium (2017), WFSR, Wageningen, NL.

\section{General courses}

VLAG PhD week (2015), VLAG, Baarlo, NL.

Personal Efficiency Program (2015), WFSR, Wageningen, NL.

Philosophy and Ethics of Food Science and Technology (2016), VLAG, Wageningen, NL.

Scientific writing (2016), WGS, Wageningen, NL.

The Essentials of Scientific Writing and Presenting (2017), WGS, Wageningen, NL.

\section{Optional}

Preparation of research proposal (2014-2015), WFSR, Wageningen, NL.

Expertise group/business unit meetings (2014-2018), WFSR, Wageningen, NL.

Project meetings with stakeholders (2014-2018), WFSR, Wageningen, NL.

\section{Teaching obligation}

Mentoring undergraduate students (2015-2018). FQD, Wageningen, NL. 
The PhD of Ningjing Liu was financially supported by the China Scholarship Council. Financial support from Wageningen University for printing this thesis is gratefully acknowledged.

Cover designed by Hao Zhang and Ningjing Liu 